空

$(200)$

T67\%

no. 0150

pt 1

\title{
Thorium Investigations
}

\section{0-1952,}

\section{Wet Mountains, Colorado}

By R. A. Christman, A. M. Heyman, L. F. Dellwig, and G. B. Gott

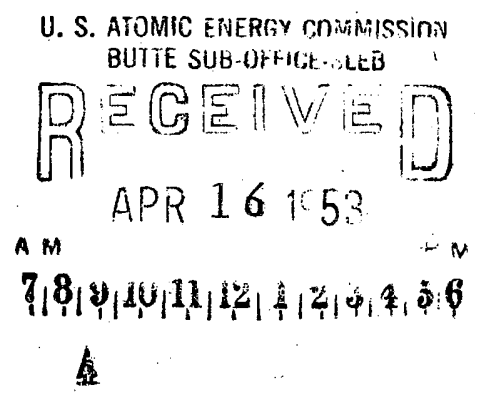

\section{Trace Elem ents Investigations Report 250}

UNITED STATES DEPARTMENT OF THE INTERIOR GEOLOGICAL SURVEY 


\section{UNITED STATES \\ DEPARTMENT OF THE INTERIOR \\ GEOLOGICAL SURVEY \\ WASHINGTON 25, D. C.}

APR 131953

AEC - 931/3

Dr. Phillip I. Merritt, Assistant Director

Division of Raw Materials

U. S. Atomic Energy Commission

P. O. Box 30, Ansonia Station

New York 23, Now York

Dear Pril:

Transmitted herewith are six copies of TEI-250, "Thorium Investigations 1950-1952, Wet Kountains, Colorado," by R. A. Christman, A. Ko Heyman, I. F. Dellwig and G. B. Gott, Pebruary 1953.

We plan to publish this report as a Survey circular after it bas been thoroughly rovised by the authors, and are asking Mr. Hosted to spprove this plan.

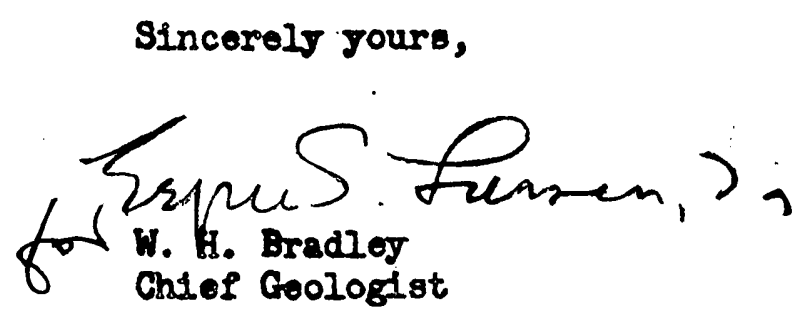

When separated from onclosures, handle this document as UNCLASIEIf? 
$*$
$(200)$
1672

Geology - Mineralogy

This document consists of 111 pages, including $38 \mathrm{~A}$ and $39 \mathrm{~A}$, plus 7 figures.

Series A

UNITED STATES DEPARTMENT OF THE INTERIOR

GEOLOGICAL SURVEY

THORIUM INVESTIGATIONS 1950-1952

WET MOUNTAINS, COLORADO*

By

R. A. Christman, A. M. Heyman, L. F. Dellwig, and G. B. Gott

February 1953

Trace Elements Investigations Report 250

This preliminary report is distributed without editorial and technical review for conformity with official standards and nomenclature. It is not for pub11c inspection or quotation.

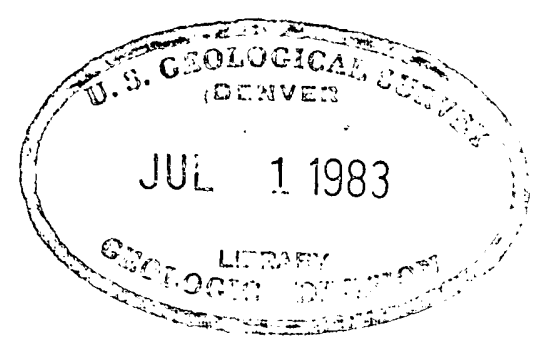

* This report concerns work done on behalf of the Division of Raw Materials of the U. S. Atomic Energy Commission

When separated from Part II, handle Part I as UNCLASSIFIED 


\section{GEOLOGY - MINERALOGY}

Distribution (Series A)

No. of copies

American Cyanamid Company, Winchester . ............ . I

Argonne National Laboratory . . . . . . . . . . . . . . . 1

Atomic Energy Commission, Washington. . . . . . . . . . 1

Battelle Memorial Institute, Columbus . . . . . . . . . . . . I 1

Carbide and Carbon Chemicals Company, I-12 Area . . . . . . . . I

Division of Raw Materials, Grants . . . . . . . . . . . . . I

Division of Raw Materials, Denver .. . . . . . . . . . . I 1

Division of Raw Materials, Hot Springs. . . . . . . . . . . I I

Division of Raw Materials, New York . . . . . . . . . . 6

Division of Raw Materials, Salt Lake City . . . . . . . . . 1

Division of Raw Materials, Richfield. ............... I

Division of Raw Materials, Butte................. 1

Division of Raw Materiala, Washington . . . . . . . . . . 3

Dow Chemical Company, Pittsburg ................. 1

Exploration Division, Grand Junction Operations Office. . . . . I

Grand Junction Operations Office.................. I

Technical Information Service, Oak Ridge. . . . . . . . . 6

Tennessee Valley Authority, Wilson Dam ............. I

U. S. Geological Survey:

Mineral Deposits Branch, Washington . . . . . . . . . . . . 2

Geochemistry and Petrology Branch, Washington . . . . . . . . . 1

Geophysics Branch, Washington .................. . I

Alaskan Goology Branch, Washington. . . . . . . . . . . . . . 1 .

Fuels Branch, Washington. . . . . . . . . . . . . . . . 1

$\mathrm{V}$. E. MeKelvey, Washington. . . . . . . . . . . . . . . I

$I_{0} R_{0}$ Page, Denver. . . . . . . . . . . . . . . . . . 2

R。 Po Fischer, Grand Junction . . . . . . . . . . . . . I

A. E. Weissenborn, Spokane. . . . . . . . . . . . . . . 1

J。 Bo Cathcart, Plant City. . . . . . . . . . . . . . 1

J。 F。 Smith, Jr。, Denver. . . . . . . . . . . . . . . . I

$N_{0} M_{0}$ Denson, Denver. . . . . . . . .......... 1

R。 W. Swanson, Spokane........................ . . . 1

L. S. Gardner, Albuquerque. . . . . . . . . . . . . . . . I

$J_{0} D_{8}$ Love, Laramie . . . . . . . . . . . . . . . . . 1

A. H。 Koschmann, Denver .................... . . 1

E。 H。 Bailey, San Francisco . . . . . . . . . . . . . . . 1

A. F。 Shride, Tucson. . . . . . . . . . . . . . . . . I

R。 P。Williams, Joplin. ..................... . 1

C. E. Dutton, Madison .................... . 1

$R_{0} A_{0}$ Laurence, Knoxville . . . . . . . . . . . . . . . 1

R. J. Roberts, Salt Lake City . . . . . . . . . . . . . . 1

W. C。 Overstreet, Shelby .................. . . 1

Q. D. Singewald, Beltsville ................. . . 1

R. A. Christman, Denver . . . . . . . . . . . . . . .

TEPCO, Washington:

Resource Compilation Section. . . . . . . . . . . . 2

Reports Processing Section................... 3

(Including master) 


\section{CONTENTS}

Abstract: : . . Page

Introduction: . . . . . . . . . . . . . . . . 9

Rock units. . . . . . . . . . . . ........ . 12

Amphibolite...................... 15

Biotite granite gneiss . . . . . . . . . . . 16

Metagabbro . . . . . . . .......... 16

Migmatite. . . . . . . . . . . . . .... . 18

Microcline granite.................. 18

Pegmatite and white granite............. 20

Syenite (?) . . : : : : : : : : . : : : . . . : . 21

Basic dike rock: : : : : . . . . . . . . . . . 21

Other units. : . . . . . . . . . . . . . . . 22

Structure o. . . : . . . . . . . . . . . . . . . 23

Thorium deposits...................... 23

Distribution ..................... 24

Mineralogy ...................... 25

Size and grade ..................... 28

Suggestions for prospecting ............... 30

Descriptions of prospects ............... . 31

Haputa Ranch area................... . 31

Rock units....................... 31

Structure . . . . . . . . . . . . . . 32

Thorium deposits. . . . . . . . . . . 33

Results of diamond drilling exploration ... . . 36

Drill holes nos. $\mathrm{Ha}-3$ and $\mathrm{Ha}-7 . . . .40$

Drill hole no. He-8. . . . . . . . 42

Drill hole no. Ha-10 ........... 43

Drill hole no. Ha-11 ......... 47

Drill hole no. Ha-6. ......... . 49

Drill hole no. Ha-2........... 52

Drill hole no. Ha-1. .......... 54

Drill hole no. Ha-4........... 56

Drill hole no. Ha-5. .......... 58

Drill hole no. Ha-9. .......... 60

Haputa Extension ................ 62

Ceology and thorium deposits.........62

Greenwood property ................. 65

Geology .................... 66

Thorium deposits................. 67

Tuttle Ranch area................. 69

Geology .................... 69

Thorium deposits. . . . . . . . . . . . 71

Other thorium deposits ............... 73

Anna Lee Iode ................... 73

Atomic Mountain claim . . . . . . . . . . 75

Barite Lode . . . . . . . . . . . . . . 79

Big Chief I claim ................ . 79

Charleston property .............. 80

Darby Extension property............ 80 


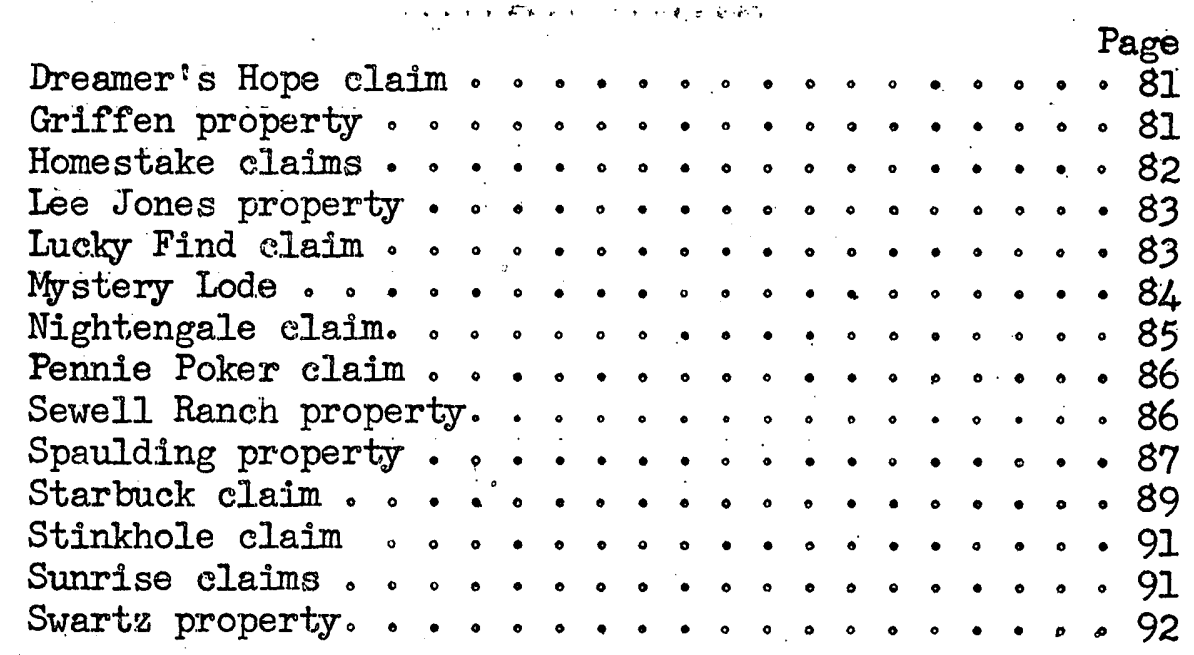

References Cited - . . . . . . . . . . . . . . o 94 Unpublished Reports。. . . . . . . . . . . . . . 94 
Figure 1. Index map of Wet Mountain area, Colorado. . . . . . 10

2. Index of known thorium areas and prospects, Custer and

Fremont Counties, Colorado. ......... In envelope

3. Geologic map of the Haputa Ranch, Custer County,

Colorado. ......................... envelope

4. Map showing shear zones, isorads, drili holes, and sample localities, Haputa Ranch, Custer

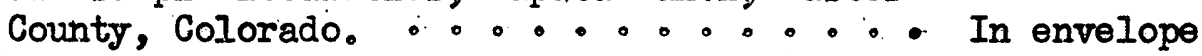

5. Section through drill holes $\mathrm{HA}-3$ and $\mathrm{HA}-7$,

Custer County, Colorado. . . . . . In envelope

6. Section through drill hole HA $\rightarrow 8$, Custer

County, Colorado. - . . . . . . . . . . . . . . 44

7. Section through drill hole HA-10, Custer

County, Colorado. .................46

8. Section through drill hole. HA-ll, Custer

County, Colorado. . . . . . . . . . . . 48

9. Section through drill hole HA-6, Custer

County, Colorado. . . . . . . . ..... 50

10. Section through drill hole HA-2, Custer

County, Colorado. . . . . . . . . . . 53

11. Section through drill hole HA-l, Custer

County, Colorado. . . . . . . . . . . . 55

12. Section through drill hole $\mathrm{HA}-4$, Custer

County, Colorado. . . . . . . . . . . . . 57

13. Section through drill hole HA-5, Custer

County, Colorado. . . . . . . . . . . . . 59

14. Section through drill hole $\mathrm{HA}-9$, Custer

County, Colorado. . . . . . . ....... 61

15. Geologic map of the Haputa extension,

Custer County, Colorado.....?.:. In envelope

16. Outcrop map of Greenwood property, Custer

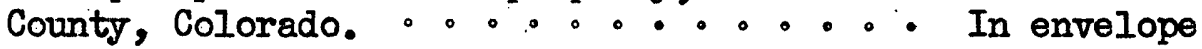

17. Geologic map of part of the Willis Tuttle

Ranch, Fremont County, Colorado. . . . In envelope

18. Isorad map of Anna Lee Lode, Custer County,

Colorado. . . . . ............... 74

19. Isorad map of Sewall Ranch, Custer County,

Colorado. . ................... 88

20. Prospects on Starbuck claim, Custer County,

Colorado. ................. 90 
TABLES

6

Page

Table 1. Correlation of rock units in text figures.

2. Spectrographic analyses of the thorite (2)..... 13

3. Summary of diamond drill hole data, Haputa ranch. . . 37

4. Analyses of samples from prospect pits and surface exposures at Haputa ranch. . . . . . . . 38

5. Analyses of diamond drill cores, samples from the holes at Haputa ranch, Custer County, Colorado.

6. Analyses of surface samples, Haputa Extension. . . . 64

7. Analyses of surface samples, Greenwood property,

Custer County, Colorado............668

8. Analyses of surface samples, Tattle ranch, Fremont

County, Colorado.

9. Analyses of surface samples from other prospects. . . 76 
THORTOM INVESTIGATIONS 1950-.1952, WET MOUNTAINS, COLORADO

\author{
$\mathrm{By}$ \\ H. A. Christman, A. M. Heyman, I. F. Dellwig, \\ and G. B. Gott
}

\begin{abstract}
ABSTRACP
The Wet Mountain thorium district was discovered in 1950 by members of the U.S. Geological Swrvey during reconnaissance investigations for uranium made on the behalf of the Atomic Energy Commission. The size of this new distriet is incompletely known; but the deposits found to date. are in an area 20 miles long and about 10 miles wide, the southwest boundary of which extends northwest from Querida and Rosita, Custer County, into Fremont County. Most of the deposits, however, are in the southeastern half of this area.

The thorium minerals occur in barite-sulfide veins along northwesttrending shear zones that cut a pre-Gambrian complex of amphibolite, biotite-granite gneiss, metagabbro, migmatite, microcline granites, pegmatite and white granite, and syenite (8). Along the shear zones are premineralization basic (lamprophyce (?)) dikes.

Thorite has been tentatively identified as the principal radioactive mineral. It is associated with baxite, quartz, galena, fluorite, Iimonite, and pyrite. Some of the shear zones perhaps can be traced for as much as 2 miles, but the largest known thorium-bearing ore body is as much as 300 feet long, 26 feet wide, and 400 feet deep. Samples from the veins contain as much as 1.6 pereent equivalent $\mathrm{ThO}_{2}$.
\end{abstract}


Eleven diamond drill holes, totaling 3,292.4 feet have explored five shear zones on the Haputa Ranch. Three ore bodies of possible economic interest are indicated in two interconnecting shear zones. No other deposits in the Wet, Mountains have been explored, or even sampled adequately to hazard an estimate as to grade and tonnage of reserves. 


\section{INTRODUCTION}

Thorium-bearing shear zones were discovered in 1950 at Haputa Ranch on the west side of the Wet Mountains in Custer County, Colorado, but the size of this new metallogenic province of thorium is incompletely known. Nost of the known radioactive shear zones are in an area about 12 miles long and six miles wide, extending north-northwest from the discovery locality at Haputa Ranch, 4 miles east of Querida, Custer County, into Fremont County ("project area" of fig. 1). Isolated, but similar deposits occur outside this area north and west of Querida and near Texas Creek (fig. 2). The entire known thorium-bearing area is about 20 miles long . and 10 miles wide. To the east of this area is the highest part of the Wet Mountains; to the west is the Wet Mountain Vailey and the high Sangre de Cristo Mountains.

Prior to the discovery of thorium in the west Mountains, the only extensive geologic investigation within the region was the study of the Rosita-Querida-Silver-Cliff-Westcliffe mining district by Emons and Cross (1896). This district comprises an area of predominantiy Tertiary volcanic rocks and contains silver, lead, gold, zinc, and copper in veins and associated breccias. To date (1952), no abnormaliy radioactive rocks have been found within this area. The thorium deposits are farther to the east, in shear zones that cut unmapped pre-Cambrian igneous and metamorphic rocks. Within the shear zones are minor deposits of silver, lead, and barite that may or may not be radioactive as well as thorium deposits devoid of silver, lead, and barite. The largest of the lead deposits is the cerrusite mine at Ilse (fig. 2 in envelope). 


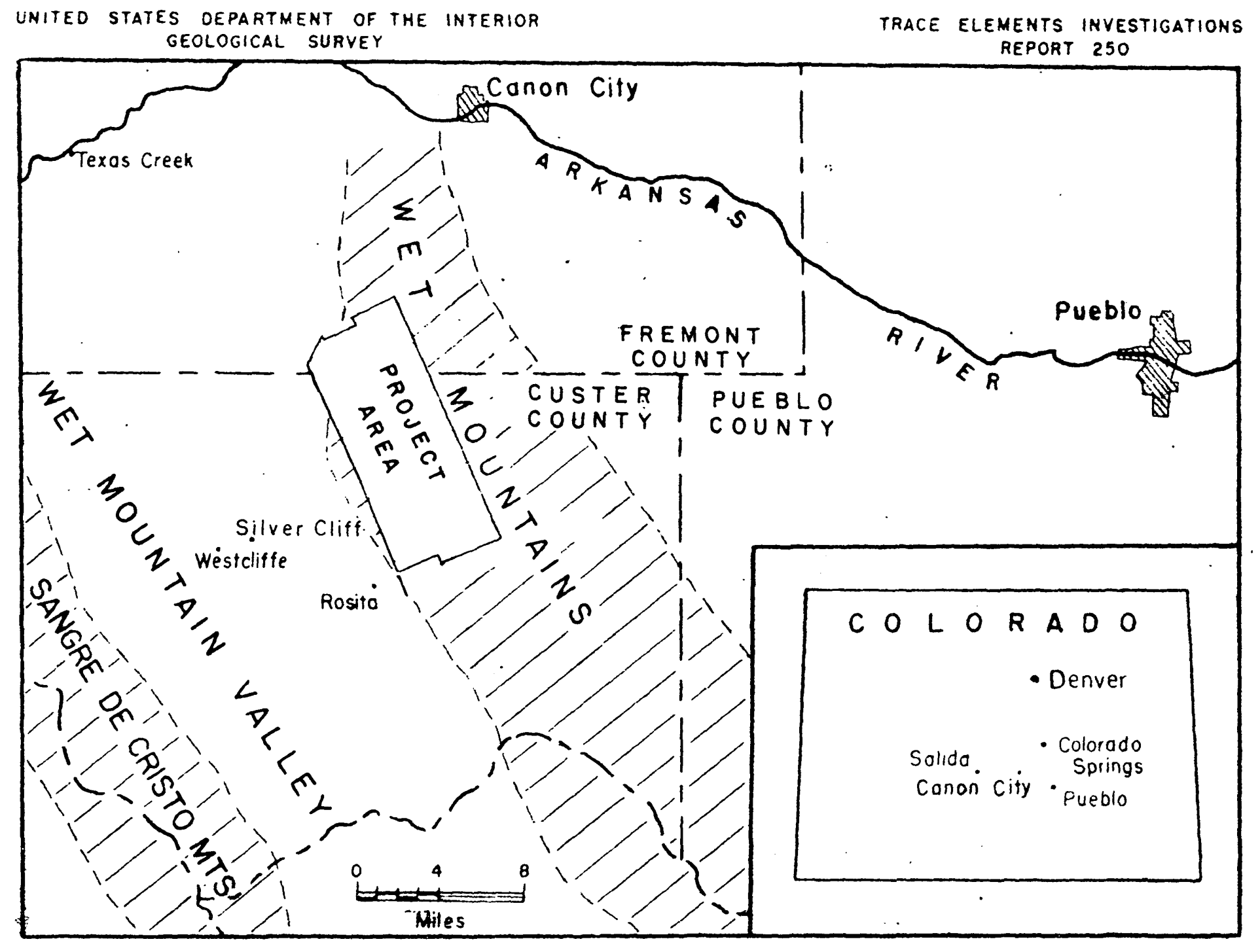

FIGURE I. - INDEX MAP OF WET MOUNTAIN AREA, COLORADO 
The radioactive shear zones were discovered by means of a car-mounted Geiger counter by. G. B. Gott and L. F. Dellwig. of the U. S. Geological, survey in July 1950 while enroute to investigate the occurrence of a slightly radioactive granite sample submitted to the Geological Survey by Lawrence Knobbe from George Haputa's ranch. Shortly thereafter thorite was identified from veins in the highly radioactive shear zones found on Haputa's ranch. During August 1950 Dellwig and Co. Go Bowles made an outerop map of the Haputa Ranch property (Gott and Dellwig, 1951); during the summer of 1951 Dellwig and A. M. Heyman mapped the Tuttle, Greenwood, and Haputa Extension properties (Deliwig, 1951). In 1950 and 1951, Gott, Dellwig, and Heyman examined numerous other prospects in the Wet Mountain area and by radiometric reconnaissance traced out several of the larger shear zones. On the basis of these preliminary studies a program of diamond drilling was proposed by the Geological Survey to explore the best known deposit at the Haputa Ranch area to determine the characteristics of this new type of mineral deposit at depth. Between November 1951 and April 1952 the U. S. Bureau of Mines, under contract to the Atomic Energy Commission, cored eleven diamond drill holes at Haputa Ranch. Kenneth Bell and assistants of the Geological Survey gamma-ray logged the drolll holes. Heyman and R. A. Christman were responsible for the goologic studies, but over-all supervision of the drilling was the responsibility of C. C. Towle, Jro, of the Division of Raw Materials, Atomic Energy Commission. Dellwig and Gott spotted the first seven drill holes and Heyman was the geologist in the field. Christman assumed responsibility for the project 
at the end of February 1952 and with Heyman supervised the later phases of the drilling program, revised Dellwig's map in accordance with the new data obtained during drilling, and prepared this report, which summarizes all information gathered in the area prior to July 1952.

As a result of the detailed and reconnaissance studies, areal mapping (at a scale of $1,6,000$ ) on a topographic base of 60 square miles was started by the U. S. Geological Survey in July 1952 (fig. 2). This study, under the direction of $Q_{0}$ D. Singewald, is part of a larger regional program undertaken by the Survey that will eventually involve mapping eight quadrangles. This report, therefore, should be considered preliminary in nature and ft should be realized that many of the ideas presented are subject to change as more information is obtained. All of the work by the Geological survey in the Wet Mountain area has been done on the behalf of the Division of Raw Materials, Atomic Energy Commission.

Special acknowledgement should be made of the personnel of the Trace Elements Section Denver Laboratory, who made all the analyses. The writers also are indebted to W. Tuttle, Mo Greenwood, I. Knobbe, E. Sparling, and particularly George Haputa, for their cooperation and aid in locating many of the radioactive deposits.

\section{ROCK UNITS}

The pre-Cambriun metamorphic and igneous rocks in the Wet Mountain area are composed principally of an older series of schists and gneisses and a younger microcline granite which commonly occurs interlayered with the older rocks. In the southern part of the area, a coarse-grained hornblende-rich rock, either a metagabbro, gabbro, or peridotite, is older than the microcline granite and younger than the gneisses and schists. All of these rocks are cut by pegmatite, and basic and acidic dikes. 
Haputa ranch (Units proposed by Dellwig (1950))

Haputa ranch (Units revised by Christman and Heyman, (fig, 3))

Lamprophyre dike

Pegmatite

\section{Basic rock \\ (occurs as dikes)}

Syenite (?)

Pegmatite and white granite

Microcline granite
(three varieties)

Migmatite

Gabbro and peridotite Metagabbro

\author{
Hornblende-andesine \\ gneiss
}

Granite gneiss

Biotite granite gneiss

Quartz-hornblende

schist

Amphibolite

Haputa Extension
(Dellwig and
Heyman, (fig. 15))

Greenwood property

(Dellwig and Heyman,

Lamprophyre dike

Lamprophyre dike
Granite pegmatite
dike

Aplite dike

Gneissic microcline

granite

Injection gneiss

$$
\text { granite }
$$

Gneissic microcline

Granite pegmatite
dike

Aplite dike

Injection gneiss

Highly altered and leached hornblendeplagioclase rock

Gabbro and peridotite Gabbro and peridotite

Diorite

Hornblende-andesine gneiss

Granite gneiss

Quartz-hornblende schist

Biotite granite gneiss and weathered hornblende granite

Hornblende-plagioclase gneiss
Tuttle ranch

(Dellvig and Heyman (fig. 17))

Lamprophyre dike

Granite pegmatite dike

Aplite dike

Greissic microcline granite

Injection gneiss

Quartz-hornblende plagioclase gneiss

Quartzite 
In Hardscrabble Canyon (fig. 2) to the east, there are good exposures of a thick layered sequence of metasediments ranging from biotite schist to plagloclasemhornblende gneiss cut and injected by subordinate amounts of microcline granite in dikes and sills. Along the Oak Creek road to the north the exposures are principally biotite granite which probably is related to the Pikes Peak granite. The rook sequences described in this report include representatives of all these rock types.

Empirical mapping units that may be distinguished locally within the Iimited tracts mapped by plane table wer set up at the Haputa, Greenwood, and Tuttlo properties, in the absence of mapping units applicable to the area as a whole, established either by areal geologic mapping or by regional "stratigraphic" studies, inasmuch as the deposits are in geologically unmapped terrain. Moreover, this report is a compilation of work done at different times by different men, the terms used to designate specific map units of the complex pre-Cambrian rocks at the various deposits are not uniform. The rocks in the Haputa Ranch area are best known, as a result of data from the drilling and the detailed geologic mapping there (fig. 3 in envelope). Table 1 shows the probable correlations between the Haputa area and the other three mapped by plane table (figs. 15, 16, 17 in envelope). The original units that Dellwig used in mapping the Haputa Ranch deposits in 1950 (Dellwig, 1951) are Included in table 1 for comparison with the revisions, made by Christman and Heyman in 1952, on the basis of the information from drilling. Future studies may show that some of these revisions also are applicable to the other mapped areas. The pre-Cambrian rocks mapped in the Haputa Ranch area are divided into the following units, listed in order of decreasing age: 1) amphibolite, 2) biotite granite gneiss, 3) metagabbro, 4) migmatite, 5) three varieties 
of microcline granite, 6) pegmatite and white granite, and 7) syenite (8). The only rocks that may be Tertiary in age are basic dikes and veins.

\section{Amphibolite}

The amphibolite is probably the oldest rock in the Haputa Ranch area. It has a uniform, fine-grained texture and is composed of hornblende, plagioclase, and minor biotite. In thin section, some varieties contain sma.l amounts of quartz. If the exposures were better, it is likely that several varieties of amphibolite and hornblende schist could be distinguished on the basis of the quiartz and biotite content and the degree of schistosity. The foliation is generally good; lineation is obscure.

Because the rock weathers easily and the exposures are poor, a much larger amount of amphibolite was found in the drill core and trenches than in surface outcrops. It is estimated that probably 30 percent of the covered areas mapped as "biotite granite gneiss and amphibolite" at Haputa Ranch may be underlain by amphibolite.

Most of the amphibolite occurs in the biotite granite gneiss as pods and stringers, generally aligned with the foliation of the granite gneiss. In places it is folded and contorted and has gneissic structure. In a few places, the rock is in dike-like masses that are at angles of less than $10^{\circ}$ to the foliation of the granite gneiss. Dellwig believes these dikelike masses mapped as amphibolite, are hornblende-andesine gneiss of slightly younger age.

This amphibolite unit (fig. 3) corresponds in age to the quartz-hornblende schist in the Haputa Extension area (fig. 15), the hornblende-plagioclase gneiss at the Greenwood property (fig. 16), and the quartz-hornblendeplagioclase gneiss at the Tuttle property (fig. 17). 


\section{Biotite granite gneiss}

The biotite granite gneiss in the Haputa Ranch area is a pink to gray, medium grained, well foliated rock. For the most part is it composed of pink and white feldspar (about 60 percent), quartz (30percent) and mafies ( 10 percent). The mafic minerals-mostly biotite and hornblende-in a few places comprise as much as 70 percent of the rock. They are responsible. for the well-developed foliation. In a few places this rock has a steep or vertical lineation.

The biotite granite gneiss is poorly exposed and weathers to a brownish rock in which the foliation is strongly emphasized. On figure 3 the location of outerops is shown by foliation symbols; many of the covered areas were assumed to be granite gneiss.

Where the biotite granite gneiss has been altered by lit-par-lit injection or migmatitic introduction of younger granitic material, it forms a resistant outcrop, and in places the biotite granite gneiss grades along strike into a ridge-forming migmatite. Rock with less than 20 percent added material was mapped as biotite granite gneiss; rock with more than 20 percent was mapped as migmatite in the Haputa Ranch area.

The biotite granite gneiss is correlated with the granite gneiss in the Haputa Extension area (fig. 15) and the biotite granite gneiss and weathered hornblende granite at the Greenwood property (fig. 16)。

The origin of the granite gneiss is unknown; it may be true igneous rock or, more likely, it is granitized or migmatized sedimentary rock.

\section{Metagabbro}

In the Haputa Ranch area, metagabbro is the second most abundant rock type. General reconnaissance indicates, however, that it is not as abundant 
elsewhere in the Wet Mountain area. The most comon variety is a medium. grained, dark-.green to black rock containing 60 to 50 percent mafic minerals and 40 to 50 percent plagioclase (Iabradorite). The mafic minerals are principally hormblende with minor amounts of green pyroxene and biotite. Where. finomgrained, the rock iss vexy diffieult to distinguish from amphibolite, especially if the pyroxene is not visible. Locally, another common variety resembles a hornblende or peridotite; this rock consists entirely of mediumtomoorse-grained hornblende with negligible plagioclase. A third variety is a stripod roek in which the plagioclase is most abundant in layers $1 / 16$ to I/8 inches thiak that separate hornblende-rich layers. In addition to variations between these types, changes in grain size and degree of foliation give the rock a variety of appearances。

In places the metagabbro has well-developed lineation, foliation, or bothg in others it is aimost granitoid. It is difficult to determine its structure in the field, however, because: 1) the rock weathers to rounded masses which are seldom in place, and 2) the outcrops are too small and scattered to deeipher the numerous variations in the foliation and lineations. The follation in a metagabbro mass north of the country road that crosses the Haputa Ranch, is well developed and parallels the regional foliation trend. In several places the giabloro contact parallels follation of the older biotite granite gnoiss (or migmatite), but in other places the contact is at right angles to the foliation suggesting that the gabbro is probably intrusive ajong this pre-existing structure。

Reconnaissance in other areas has indicated that additional work is necessary to determine the variations and origin of this unit. Rocks that are megascopically similar appear to be igneous intrusions in one place and metasedimentary (?) gneisses in other places. 
The metagabbro unit (fig. 3) is the same as the "gabbro and peridotite". unit at Haputa Extension (fig. 15) and the Greenwood property (fig. 16). The core fram diamond drill hole Ha-l and Ha-2 showed that the hornblende-xicho. plagioclase-free rock, originally mapped as peridotite by Dellwig, is actually gradational with a rock containing more feldspar. Its spotty distribution suggests that it is a hornblenderrich facies of the metagabbro.

\section{Migmatite}

The biotite granite gneiss in many places has been intruded lit-par-lit by the younger microcline granite to form migmatite or injection gneiss. The introduced granitic material varies in amount from intrafoliational films to sills several feet wide; most commonly it occurs as seams of small augen-like masses along the foliation planes. The migmatite is generally more resistant than the surrounding biotite granite gneiss and forms ridges parallel to the trend of foliation.

The migmatite, as mapped (fig. 3), is a unit gradational between biotite granite gneiss and microcline granite. It contains 20 to 80 percent microclino granite. Migmatites commonly surround the masses of younger microcline granite and in some places appear to be localized near the shear zones.

The migmatite is probably the same rock as the "injection gneiss" shown on figures 15, 16, and 17。

\section{Microcline granite}

Several varieties of microcline granite occur throughout the area as stringers along the foliation planes of the gneisses and as sills, dikes, and small pods or masses. The granite is characterized by a large percentage of microcline feldspar and a pink color. In the Haputa Ranch area, three varieties of microcline granite are closely related in age. In most cases, they easily ean be distinguished in the field. 
An alaskitic variety is the most common type and is most readily recognized. It is characterized by a high quartz content and by a paucity of mafic minerals; a small amount of biotite is sometimes present. It is commonly fine-grained to "sugary" in texture and may be quite friable when weathered; in some places local streaks of coarser material give the rock a slight foliation.

A coarse-grained facies of the alaskitic granite is lodally common in the vicinity of drill holes Ha-3 and Ha-7. This rock is medium- to coarse-grained with conspicuous large grains of quartz, although the total quartz content is probably less than in the "sugary" textured facies. The mafic content is relatively high (about 10 percent), and consists of both hornblende and biotite. Within a few feet along the strike, the coarse-grained facies was observed to grade into the "sugary" facies. In some places the rock shows weak foliation and both types occire as small masses; the "sugary" type occasionally occurs as pods or corsscutting dikes. The alaskitic granite caused most of the migmatitization of biotite granite gneiss in the Haputa Ranch area. It also occurs as sills where thicker layers have been injected along the foliation planes.

The second variety of microcline granite is characterized by a higher percent of biotite, moderate to low quartz, and a lower mierocline content than the other microcline granites. It is generally distinguished by its gray color. This facies occurs mostify as sills or layers along the foliation north of the Haputa Ranch area where it is the dominant type of microcline granite. This variety (fig. 3) is probably gradational with the other two types of microcline granite.

The third variety of microcline granite is characterized by its massive or dense appearance, red feldspar, and low quartz content; most of the rock appears to be composed of red feldspar and variable proportions of hornblende. 
It is medium- to fine-grained but does not have clearly defined mineral grains. The rock commonly is highly fractured; the fracture surfaces are smooth and stained with limonite. It occurs principally as small dikes that cut the amphibolite, biotite granite gneiss, and metagabbro. It appears to cut the alaskitic granite in one locality.

The high potash content of the microcline granites is reflected in the radiometric logs of the drill holes. The radioactivity of many of these bodies is about twice background. (See fig. 9.)

The microcline granite in the Haputa Ranch area roughly corresponds to the gneissie microcline granite in the other areas (figs. 15, 16, 17).

\section{Pegmatite and white granite}

Small pods and dikes of pegmatite and white granite occur throughout the Haputa Ranch area. The pegmatite is composed of various proportions of white quartz and pink microcline with some mica or hornblende. These minerals may be as much as four inches in diameter; some quartz and feldspar is in graphic intergrowth. Other minerals gienerally are absent but one sixinch pegmatite in drill hole $\mathrm{Ha}-\mathrm{l}$ contained several blades of an unidentified, light brown, radioactive mineral.

A white granite is associated with the pegmatite, but is too rare and too limited in size to be mapped as a separate unit. It is a coarse-grai ned granite composed entirely of white feldspar and quartz. Pod-like masses in the Haputa Ranch area occur most frequently along the contacts of, or within, metagabbro. In places, the pegmatite has been irregularly emplaced along shear zones or faults. Small pegmatitic stringers of white granite are very auruerous in the cores of metagabbro and migmatite. The pegmatite and white granite units of figure 3 correspond to the granite pegmatite shown on figures 15, 16, and 17. In one place on the Greenwood property, the 
pegmatite is younger than aplite (syenite?)

\section{Syenite (?)}

A dike similar in appearance to ones designated by Emons and Cross (1896) as syenito in the area to the west was mapped along the northeastern margin of the Hapute Ranch area. The rock is fine-grained; in some specimens the individual grains cannot be easily detected megascopically. It is a smoothly fractured, homogeneous, dull reddish-brown rock, that is resistant to weathering and forms conspicuous float. In some places, the rock has the strong fetid odor which is characteristic of the mineralized rock in the district and in a few places slightly radioactive. At the Haputa Ranch area it cuts all rock units with which it is in contact. If, as seems probable, it is contimuous beneath the valley alluvium between the two outcropping areas, the dike has a length of over 2,000 feet; it is five feet wide where it was cut by drili hole Ha-9. This rock forms aplitic-textured dikes throughout the district and has been mapped as aplite on figures 15,16 , and 17.

\section{Basic dike rock}

Basie dikes - also mapped as lamprophyre in the Haputa Extension (fig. 15), Greenwood (fig. 16), and Tuttle Ranch area (flg. 17) - occur along most of the major radioactive shear zones or faults in the Wet Mountain thorium district. Two types of basic dikes were identified in the Haputa Ranch area; an older type that appears to be displaced along the shear zone No. I (fig. 5) and a younger type that parallels the shear zone and shows no evidence of offset.

The only known basic dike of the older type is a fine-grained to medium fine-mgrained, dark green rock composed chiefly of small hornblende crystals and abundant pyrite in a fine-grained groundmass. It has an aphanitic border 
which contains white and pink calcite anygdules.

The younger dike rocks are aphanitic to fine-grained, blue-gray, greengray, or dark gray andesiticappearing rocks. Phenocrysts are seldom seen megascopically, although in the thin section the rock contains mumerous feldspar laths. The rock is comonly amygduloidal; the amygdules are calcite and, rarely, purple or white fluorite. The rock is hard, dense, and forms a competent wall rock where unweathered.

The relationship of the younger dikes to the thorirm veins appears to be purely structural. The dikes are only slightily radioactive, except, where they are eut by small veinlets of radioactive minerals. The dikes are commonly highly altered; in most places they are essentially limonite. In some places they cccupy one side of the shear zone and the veins occupy the other side, in others they form the wall rock of the veins. There may be as much as 20 feet of sheared rock between the radioactive vein and the dike.

\section{Other units}

Units of a "highly altered and leached hornblende-plagioclase rock" and "diorite" were mapped at the Greenwood property (fig. 16). These have no apparent equivalents in the Haputa Ranch area. The diorite is limited to two outcrops in a 50 by 150-foot area in the southern part of the map area and is a gray, granitoid rock composed largely of pla gioclase and subordinate amounts of hormblende. The "highly altered and leached hornblendemplagioclase rock unit includes several varieties of sericitized, epidotized, chloritized, and partily silicified rocks that are limited to a small area in the southern part of the map.

Garnetiferous quartzmbiotite gneiss and quartzite, were mapped at the Tuttle Ranoh property (fig. 17) and with the hornblende-plagioclase gneiss are the oldest rocks mapped. They correspond stratigraphically to the 
amphibolites in the Haputa Ranch area: The thinly laminated, hard, gray quarzite crops out as a lens 70 feet long. The garnetiferous quartzbiotite gneiss is a dark gray to brown, fine-grained rock composed chiefly of hornblende and plagioclase; the minor constituents are biotite, quartz, and garnet -o- ranging from pinhead - to pea-size. Some of the hornblende is altered to biotite. In places granitic material has been added to the gneiss to form a series of garnet-bearing rocks that grade from garnetiferous quartz-biotite gneiss to microcline granite. A similar appearing garnetmearing gneiss is found at the Greenwood property (fig. 16) but is too scarce to be mapped separately, and so is included in the hornblende-plagioclase gneiss unit.

\section{STRUCTURE}

In its broader aspects the structure/throughout the area appears to be simple, although in detail it is very complex. The metamorphic and the igneous rocks have a regional trend of $\mathrm{N}_{0} 45^{\circ}-75^{\circ} \mathrm{E}$; the average is $\mathrm{N}_{0} 60^{\circ}$ E. The foliation dips $45^{\circ} \mathrm{NW}$. to vertical; the average is about $80^{\circ} \mathrm{NW}$. Local variations resulting from drag folds or faults are uncommon. The area at first appears to be monoclinally folded, but incomplete evidence. from areal mapping dane in 1952 suggests that it may be isoclinally folded on a large scale. Lineation is rare. Many shear zones trend about N. $50^{\circ}$ W. and transect the pre-Cambrian rocks (figs, 3, 15, 16 and 17). These shear zones are nearly vertical and range from less than a foot to twentysix feet in thickness.

\section{THOPIUM DEPOSITS}

Although many prospect pits and surface exposures, made in prospecting for base and precious metals, are available for study, the presence of thorium in them has only recently been discovered and none of the deposits has 
been sufficientily explored underground to outline the shape of the thoriumbearing ore bodies. Drill holes at the Haputa Raneh showed that ore bodies are not coextensive with shear zones and, also, that some ore bodies extend to depths of more than 400 ifeet, whereas, others are less deep.

The thorite and rare-earth minerals occur as fracture fillings, as coatings on fractures, and as replacement bodies in sheared rock. There is a close association of sulfides, fluorite, and barite, suggesting that the deposits formed at low temperatures. The deposits are tentatively designated as of Tertiary age because they are younger than the basic dike rocks which are believed to be Tertiary.

\section{Distribution}

The known thorium deposits of the Wet Mountains are scattered irreguIarly, as shown by figure 2, over an area about 10 miles wide that extends about 20 miles from northeast of Rosita to about six miles southeast of the village of Texas Creek. However, the precise boundaries of the thorium-. bearing province remain to be delineated. The deposits are in shear zones, within any one of which the ore shoots have irregular distribution, as is illustrated by the isorad map of ore bodies in the Haputa Ranch area (fig. 4, in envelope). The localization of thorium deposits in the shear zones shows no apparent relation to the type of country rock, to the intersection of structures, or to changes in strike and dip of the shear zones.

Indiviäjal known radioactive shear zones appear to extend for considerable distances; shear zone No: I, on the Haputa Ranch property, has been traced for a distance of 7,000 feet and is in a direct line with the Anna Lee property another 10,000 feet to the northwest. The Little Maud, Atomic Mountain, and Greenwood deposits may be on a shear zone that is exposed at intervals for a Iinear distance of 12,000 feet. The shear zones in the Wet Mountain 
area have not been traced contimuously throughout their extent, and the large areas between known deposits have not been studied in detail.

\section{Mineralogx}

The most abundant minerals associated with the thorium are rare-earth minerals, quarti, barite, limonite, and hematite. Tho less common vein minerals include purple fluorite and smaller amounts of yellow and white fluorite, siderite, galena, chalcopyrite, bornite, and pyrite. Silver and gold are reported to have been found in small quantities. The quartz is commonly massive and white but also occurs as large crystals in vugs. Most of the crystels are smoky and display well-developed interfor zoning. The barite ranges in color and form from white crystalline cloavage masses to red cryptocrystalline granular masses. The cleavage angle is between $80^{\circ}$ and $85^{\circ}$ rather than the normal $90^{\circ}$; if it were not for the high specific gravity the mineral could be mistaken easily for calcite.

In areas of strong radioactivity, small veinlets and blebs of the thoriumbearing mineral, tentatively identified as thorite, can usually be found. The mineral has a dark red-brown color, a greasy luster, a hardness greater than 5 and has a tendency to break with a splintery, conchoidal fracture. The thorite (?) in quartz commonly is surrounded by a series of radiating fractioes.

The thorirm- and rare-earth-bearing minerals are rarely recognizable except by the use of a Geiger counter. They normally occur with abundant hematite and limonite or alone in red-stained rocks. Because of the finegrained nature of the material and the masking by the iron oxides it is not known whether this material represents (1) disseminated thorite, (2) hydrated and altered thorite, (3) or thorium molecules in the lattice of other, minerals. 
An exact identification of the thorium-bearing material is being made at the laboratories of the Geological Survey in Washington. An X-xay examination of the material is reported to indicate that the mineral belongs to the thorite family. Speetrographic analyses of two specimens (table 2) show that the mineral contains a large number of constituents. It seems to differ from typical thorite by its laxger content of iron and its smaller content of uranium; the mineral possibly may be ferro-thorite. In other districts a similar appearing thorium mineral is reported to be hydrated thorite.

Rare-rearth oxides are associated with the thorium in the veins, but the exact form and amount are not known. The content of rare-earth oxides have been detexmined by subtracting the percent of $\mathrm{ThO}_{2}$ from the combined percentage of raxewearth and thorium oxides; thus, the raremearth determinetion Is dependent upon the accuracy of the $\mathrm{ThO}_{2}$ analyses.

Most of the mineralized material in the shear zones has a strong fetid odoss it is especially strong in some of the reddish stained granitic rocks. The odo* can be detected only for a few seconds after the rock has been broken. The odor was thought to be caused by selenium compounds but a ehemical analysis of the rock showed only traces of selenium. The volatile compounds may have escaped during the grinding of the sample. It has been suggested also that the odor may be due to arsenic or phosphorous compounds. Regardless of its origin, the gas is characteristic of the Wet Mountain thorium area and is useful in tracing the radioactive zones where other evidence of minexalization is lacking.

A megascopic study by Dellwig of the paragenesis of the minerals in the Haputa Raneh area indicates that the siderite was deposited first and was followed by fluorite, quartz, and the copper sulfides. The galena and barite axs considered to be only slightly younger. The final stage in the sequence 
Table 2.-Spectrographic analyses of the thorite (?)。

\begin{tabular}{|c|c|c|c|c|c|c|c|c|c|c|c|c|c|}
\hline & Si & AI & $\mathrm{Fe}$ & $\mathrm{Ti}$ & $\operatorname{Min}$. & $P$ & $\mathrm{Ca}$ & $\mathrm{Mg}$ & $\mathrm{Ba}$ & $\mathrm{Be}$ & $\mathrm{Co}$ & $\mathrm{Cr}$ & \\
\hline$R A-86$ & $x_{0}$ &.$x$ & $x x$ 。 & $.0 x$ & $.0 X$ & $\mathrm{x}$ &. $\mathrm{X}$ & $.0 x$ &.$x$ & $.00 x$ & $.0 x$ & $.0 x$ & \\
\hline \multirow[t]{2}{*}{$\mathrm{RA}-.87$} & $x_{0}$ &.$x$ & $x x$. &.$X$ & $.00 x$ &.$x$ &.$x$ & $.0 x$ & $.0 x$ & $.00 x$ & $.00 x$ & $.0 X$ & \\
\hline & $\mathrm{Cu}$ & $\mathrm{Ga}$ & $\mathrm{Ge}$ & Mo & $\mathrm{Ni}$ & $\mathrm{Pb}$ & Sc & $\mathrm{Sn}$ & Sr & Th & $\mathrm{V}$ & $\mathrm{Y}$ & $\mathrm{Zr}$ \\
\hline$R A-86$ & $.00 x$ & - & $.00 x$ & $.0 x$ & $.0 x$ & $.0 x$ & $.0 x$ & $.00 x$ &.$O X$ & $x x$. & $.0 x$ &.$x$ & $.0 x$ \\
\hline$R A-87$ & $.00 x$ & $.000 x$ & $.00 x$ & $.0 X$ & $.00 x$ & $.0 X$ & $.0 x$ & $.00 x$ & $.0 x$ & $x x$. & $.0 X$ &. $\mathrm{X}$ & $.0 x$ \\
\hline
\end{tabular}

Looked for but not found: $\mathrm{Na}, \mathrm{Ag}, \mathrm{As}, \mathrm{Au}, \mathrm{B}, \mathrm{Bi}$, In, Ir, $\mathrm{Hf}, \mathrm{Hg}$, $\mathrm{La}$, $\mathrm{Li}, \mathrm{Nb}, \mathrm{Os}, \mathrm{Pd}, \mathrm{Pt}, \mathrm{Re}, \mathrm{Rh}$, Ru, $\mathrm{Sb}, \mathrm{Sm}, \mathrm{Ta}$, $\mathrm{TI}, \mathrm{Te}, \mathrm{U}, \mathrm{W}$, and $\mathrm{Zn}$.

Not looked for: $\mathrm{K}, \mathrm{Ce}, \mathrm{Nd}$. 
is the deposition of the thorium and rare-areth minerals although these are In parot, contemporaneous with the barite.

\section{Size and grade}

The dimensions of the thorium-bearing shear zones of the Wet Mountain district, are incompletely known, but to date more than 32 separate, abnormally radioaetive genes have been partially investigated. Shear zone No. I in the Haputa Raxich area (figs. 3,4 ), which may be abnomally radioactive over a Iinear distance of 17,000 feet, locally is 26 feet wide. Another zone which may extend 12,000 feet laterally through the Greenwood and Atomic Mountain propertiles is several feet wide.

The sizes of ore bodies within the radioactive shear zones depend in part upon the arbitreary cut-off grade used in determining their limits. Whthout, a price schedule for thorium it is impossible to determine what grade is "ore", consequently a grade of 0.3 percent $\mathrm{ThO}_{2}$ was used in this study in delimiting ore shoots. On this basis the longest known ore body is the Anra Lee propexty (fig. 18). It extends along the shear zone continuously for 400 feet and discontinuously for 800 feet. Where observed the vein is 1.3 feet thick and consists of two inches of high-grade thorite in lor er grade thorium-bearing rock (table 9). No information is available as to the rertical extension of this deposit. The larger of two ore bodies In shears zone No. I in the Haputa Ranch area is roughly 200 feet long and 6 feet wide at the surface; it extends at least 400 feet in depth; a thickness of about 26 feet of radioactive material was cut in drill hole Ha-3 ( $f$ Ig. 5). The othex ore body in shear zone No. I is 160 feet long and 2 to 7 feet thick on the surface. It extends more than 140 feet in depth where a droill cut 12 feet of vein material. These, however, are the exceptional, high grade ore bodies; the other known deposits probably contain 
a Lower grade of ore and probably are smaller in size.

Sampling and assaying problems make It difficult to determine the grade of the thorium deposits. The thorium (I) is irregularly disseminated throughout mineralized zones, or (2) decreases outward from high-grade veins or shoots, one to two inches thick. In either case it is difficult to obtain a representative sample.

The method of assaying used to determine the grade of the thorium deposits has been to compute the equivalent e $\mathrm{ThO}_{2}$ by radiochemical methods. The $\mathrm{TThO}_{2}$ is computed by subtracting the chemieal uranium from the equivalent uranium and multiplying the difference by a conversion factor of 5.7. This factor, which varies with the radiometric equipment, is the one used by the Trace Elements Section Denver Laboratory where all of the samples were analysed. The $\mathrm{OThO}_{2}$ value is based upon the assumption that when the chemical uranium is subtracted from the equivalent uranium, the remaining radioactivity is due solely to thorium in equilibrium with other radioactive elements in the series.

A few semiquantitative spectographic analyses were made. The results appear on Tables 2, 5, and 9.

The ehemical determination of thorium is difficult, and the difficulties increase when large amounts of barium are present such as in the samples from the Wet Mountains. Samples have been submitted for chemical analyses, but the results are unsatisfactory. In general, the chemical analyses showed a much lower $\mathrm{ThO}_{2}$ content than the equivalent $\mathrm{ThO}_{2}$.

The $\mathrm{eThO}_{2}$ content of the shear zones, from wall to wall ranges from a trace up to 0.5 percent. The uranium and rare-earth oxide contents are as much as 0.009 and 1.53 percent, respectively. The grade varies not only along strike and down dip but also across the width of the shear zone. 
Consequently, careful sampling and analysis is necessary to determine actual thorium and uranium content. These same samples also can be used to determine the content of rare-oarth minerals, although additional study may possibly show that these metals may also be concentrated in non-radioactive parts of the shear zones.

The highest grade parts of the radioactive shear zones are thin veins or groups of veins that assay as much as 6.8 percent $\mathrm{TThO}_{2}, 0.027$ percent uranirm, and 1.3 percent combined rare earth oxides. Several channel samples from the Anna Lee property contained more than 1,0 percent chemical thorium (table 4); one contained 3.8 percent. The average grade of these highgrade deposits probably is less than 0.5 percent thoria, 0.002 uranium, and 0.5 percent rare-earth oxide.

\section{SUGGESTIONS FOR PROSPECTING}

Although our knowledge of the distribution of the thorium is limited, the thorium reserves in this area appear to be extremely large. Many of the radicactive shear zones can be identified by mmerous prospect pits which were dug along them at some previous date in search for silver, gold, lead, or barite. They can also be traced by the presence of (1) radioactivity, (2) siderite, quartz, and/or barite, (3) basic rocks, commonly completely altered to limonite, (4) fetid, altered rocks, (5) characteristic red-stain on the sheared roaks, or (6) green or blue amphibole (8) minerals coating the fractures of the country rock.

In some zones, the most abundant radioactive material is in areas which contain barite and/or smoky quartz; in others it is in areas containing only thorite minerals (as veinlets) and intensely red-stained country rocks. No mineralized or altered rock from this region can be rejected by visual inspection as not containing thorium. All such rocks should be tested with 
radiation detection instruments such as the Geiger or gama scintillation counter. The gamma scintillation counter is more sensitive to slight changes in radioactivity and is very useful for making quick evaluations of an area. It is especially useful in areas of light cover where the soil may still contain the thorium minerals.

\section{DESCRIPTION OF PROSPECTS}

\section{Haputa Ranch area}

The first radioactive minerals to be discovered in the Wet Mountains were found on George Haputa's ranch, 11 miles east of Westcliffe (fig.2) in SEI/4 sec. 12, T. 22 S., R. 71 W. This local area was mapped in 1950 by Dellwig and Bowles (Dellwig and Gott, 1951); their map was revised by Christman and Heyman in 1952 subsequent to the diamond drilling exploration program in 1951-52. Many of the contacts on this map (fig. 3) are approximate or inferred because of the complex geology and the poor exposures. The outlines of the outcrops are not shown, but their distribution is given by Dellwig and Gott (1951).

\section{Rock units}

The rock units shown by figure 3 are described on pp. $6-16$ of this report, but a few words more about the older hornblenderrich dike are in order. This dike, discovered in drill holes Ha-3 and Ha-7 weathers so easily that a careful search revealed no float from it, though later bulldozing exposed it over a width of 22 feet. Therefore, more dikes of this type may be concealed beneath the soil. The dike strikes about N. $70^{\circ}-W_{0}$ and dips $77^{\circ}$ NE. Although it is known to change dip with depth, its position in drill holes $\mathrm{Ha}-3$ and $\mathrm{Ha-7}$ suggests that it has been displaced (fig. 5) 50 feet along the main zone, either by orogenic movement or by dilatation by later dikes and veins along the shear zone. No radioactivity is associated with the dike but it is altered, and fetid rock is present at its contacts. 
Strusture

The provaliling foliation in the biotite granite gneiss and in the migmatite strilkes about N. $60^{\circ}$ E. and dips about $80^{\circ}$ NW. However, 1ocally near the contaets with metagabbro the strike may pallel the contact, deviating as much as $90^{\oplus}$ from the prevaling trend.

Lineation was obsex'ved only in a few locations; no interpretations were possible. The oaly folds recognized are minor contortions of the amphibolite within the biotite granite gneiss. Changes of strike in the granitic rocks, othex than those associated with the metagabbro, are nerer abrupt ox large and probably represent minor flextures formed when the rocks were foliated.

The dominant structural features of the Haputa Ranch area (fig. 3) are five mineralized shear zonss. Evidence concerning the size and shape of theso structural breaks is limited to exposures in prospect pits and data from drill holes. The shear zones have a genexal trend of $N_{0} 50^{\circ} \mathrm{W}$ and a vertieal ar nearly vertical dip. In many places their trend is reflected in the stroike of the joints. In the vicinity of hole Ha-6, two en echelon shears are conneeted diagonally by a one-foot wide tensional fault (fig. 4). . The laxger contimuous shears contain basie dikes whereas the smallex ones, such as this tension fault, do not contain dikes: both may be mineralized. The largest shear zone, No. I, at drill hole Ha-3 has a maximum width of 26 feet, Is 13 feet wide at hole Ha-8, I2 feet wide at hole Ha-6 and 8 feet wide at hole Haw2. In a few places as south of drill hole Ha-3, the break is narrow and is more correctly called a fault.

The displacement along shear zone No. 1 appeaxs to be relatively small. About midway betwoen the sites of holes Ha-8 and Ha-1l, two pegmatite bands and a migmatite band, having slightly divergent strikes, are displaced about 20 feet along the fault with the northeast side having moved southeast. 
The "older" basic dike occurring near drill hole Ha-3 was intersected in drill holes $\mathrm{Ha}-3$ and $\mathrm{Ha}-7$ on either side of the shear zone No. 1. A maximm vertical displacement of about 50 feet is shown for this dike (fig. 5). Flsewhere, the displacement along the faults is not evident, or very small.

Shear zones No. $I$ and No. 2, can be traced for considerable distances; the structure is proven to extend at least 7,000 foet and is believed to extend over 17,000 feet. It seems surprising that the displacement is apparentiy small.

\section{Thorium deposits}

All the shear zones at Haputa Ranch are very weakly radioactive; however, only about 15 percent of their lengths is sufficiently radioactive to measure twice background on a gama scintillation detector. The position of these higher concentrations of radioactivity mark the position of thorium ore shoots exposed at the surface. The size and shape of the anomalies is shown by the isorads on figure 4. The remaining 85 percent of the shear zone is either too deeply covered, or the radioactivity is too weak, to show isorads of this type. At the shear zones near drill holes $\mathrm{Ha}-3$ and Ha-4, samples collected along the vein ranged from 0.03 to 0.38 percent equivalent $\mathrm{ThO}_{2}$; yet only in the vicinity of the shaft in the northwest end of shear zone No. 3 was the quantity of radioactive material at the surface sufficient to give a radioactivity of twice background.

The shape of the isorad lines gives an approximation of the size of the high-grade thorium deposits exposed at the surface. The actual dimensions of an individual deposit, as given in this report, are determined by the cutoff grade assumed, by the type of analytical values used, and by the type of reserves-indicated or inferred-calculated. In this report the term "ore" is used for rock containing more than 0.3 percent $\mathrm{ThO}_{2}$. 
The areas having radioactivity greater than twice background were located with a gamma scintillation counter and, are plotted on figure 4 as the areas within the 200 CPM (counts per minute) Isorad 1ine. The area along the shear zones was examined very carefully so that other ore shoots are un1.ikely to bo found exposed. The ore body at drill hole Ha-8 was found by the gamma seintillation counter through eight inches of soil; the drill hole was spotted on the basis of the counter readings. If the instarument can locato an ore body through light soil cover, the possible areas for nearsurface ore shoots at Haputa Ranch are those of thick cover.

The garma scintillation detector proved to be very valuable for locating a the dimeasions of the thorium-rich areas along, the shear zone. The isorad map was made by irregulaxly traversing the shear zone and locating the points of $200,300,400$, and 500 counts per mimute (over a background of $100 \mathrm{CPM}$ ) by pinning pleces of colored crepe paper to the ground with nails. After $a$ few pointis were located the shape of the isorad lines could be seen on the ground and additional readings were made at eritical points. The data were then plotted on the map by measurements from a selected central point.

No quantative correlation can be made between the isorad lines and the amount of radioactive material because of the masking effect of much cover and the anomalous effect of float. Obviously a reading of 500 CPM In a prospect pit where ore is exposed represents less ore than the same reading in an area covered by eight inches of soil. The isorads are simply an indication of the distribution of the radioactivity.

At shear zone No. I, about 500 feet of the 1,800 feet mapped, had radioactivity gxeater than twice background. The ore body in the vicinity of dxill holes $\mathrm{Ha}-3$ and $\mathrm{Ha}-7$ is 200 to 300 feet long, 6 feet thick where exposed in the shaft, and drilling has indicated its presence at a depth of 
400 feet. The ore body in the vicinity of drill hole Ha-6 is about 160 feet long, 5 feet thick where exposed on the surface, and over 170 feet deep. The ore body in the vicinity of drill holes Ha-10, Hawl, and Ha.6 is about 250 feet. long, several feet wide where exposed and of a very shallow depth. Smallex ore bodies are present above drill hole Ha-4 in shear zone No. 3, above drill hole Hawl. and midway between dri]1 holes Ha-8 and Haw10.

The veir exposed in the shaft and cut by drill holes $\mathrm{Ha}-3$ and $\mathrm{Ha} \rightarrow 7$ consists prineipally of quartz, barite, and much limonite. The thorite (?) ocerrs as blebs in the quartz and barite and probably is disseminated in the 1.imonite. The Iimonitic alteration of the basie dike is very strong in this area. Some of the amygdules of the dike are filled with fluorite. Where the vein was cut by the dxill holes, only sparse barite and quarta were found; most of the ore zone consisted of altered granite or earthy Iimonite or hematite. One sample from the shaft contained 8.1 percent equivalent $\mathrm{ThO}_{2} 3$ two others contained 0.1 percent equivalent $\mathrm{ThO}_{2}$ (tables 4,5 ).

The ore body at drill hole Ha-8 contained no visable quartz or barite. The jufoot ore zone contained only thorite, abundant limonite, hematite, and altered granitic rock. Spectrographic analyses of the ore material (table 5) shows that the gttrium may be present in as much as 0.8 percent, but that other rare earths are present only as traces. Samples (RA-93 and RA-85) collected in the bull-dozed trench contained 2.6 and 4.6 percent equivalent $\mathrm{ThO}_{2}$. $(t a b l o 4)$

The northern part of the ore body in the vicinity of drill holes Ha-10 and Ha-ll is very similar to the ore near drill hole Ha-8. In the southern part of the body near drill hole $\mathrm{Ha}-6$, however, quarti and barite are abundant constituents of the vein. Several of the samples from this area have very high $\mathrm{ThO}_{2}$ values (table 4 ): these range from 0.1 to 4.2 percent equivalent $\mathrm{ThO}_{2}$. One sample (RA-97) has a possible rare-earth oxide content of 1.5 percent. 
No ore bodies (more than 0.3 percent $\mathrm{ThO}_{2}$ ) were found along the 800 -foot strike'length of shear zone No. 2. The shafts and pits in the vicinity of Ha-2 contained small pockets of galena. Little radioactivity was found; the highest sample contained 0.21 percent equivalent $\mathrm{ThO}_{2}$. Drill hole Ha-l failed tio locate ore material beneath a highly radioactive prospect pit-mone sample (GGur76) from this pit contained 16.7 percent equivalent $\mathrm{ThO}_{2}$. The relation of this deposit, to shear zone 2 is not known-

The highest thorium analysis along the combined exposure-m, 350 feet-of shear zones No. 3 and No. 4 was from the drmp of the shaft which contained 0.4 percent equivalent $\mathrm{ThO}_{2}$ (sample GG-55). The prospect pits each of drill hole sit Ha-5 contain minor mounts of copper sulfides and pyrite. Drill holes $\mathrm{Ha}-4$ and $\mathrm{Ha-5}$ failed to intersect rock containing more than 0.1 percent $\mathrm{eThO}_{2}$.

On shear zone No. 5, the most radioactive sample (ID-18) contained 0.1 percent equivalent $\mathrm{ThO}_{2}$, at depth the shear zone was weakly radioactivè. The area around the prospect pits and shafts, near drill hole Ham, is highly altered; quaxti, siderite, abundant limonite and minor sulfides are present.

\section{Results of diamond drilling exploration}

Eleven diamond drill holes totaling 3,292.4 feet have explored the thorium-bearing veins on Haputa Ranch. Five holes (Ha-3, -6, -7, -8, -10, -11) explore shear zone No. I over a strike length of 1,440 feet; three (Haw $1,2,-6$ ) explore shear zone No. 2 over a length of 600 feet; two (Ha-4 and -5) explore shear zones Nos. 3 and 4 over a length of 245 feet; and one hole (Ha-9) explores shear zone No. 5 (figure 4 ). The position of the drill holes (fig. 3) and the location of surface samples is given in figure 40 A summary of the data regarding the drill holes is given in table 3 and the analyses of the samples from the surface and from the drill core is given in tables 4 and 5. 
Table 3.--Summary of diamond drill hole data, Haputa ranch

\begin{tabular}{|c|c|c|c|c|c|c|}
\hline Hole number & $\begin{array}{c}\text { Location } \\
\text { (shear zone) }\end{array}$ & $\begin{array}{l}\text { Length } \\
\text { (feet) }\end{array}$ & Direction & Inclination & $\begin{array}{c}\begin{array}{c}\text { Depth of first core I/ } \\
\text { (feet) }\end{array} \\
\end{array}$ & $\begin{array}{c}\text { Core recovery } \\
\text { (percent) }\end{array}$ \\
\hline $\mathrm{Ha}-\mathrm{I}$ & $2 ?$ & 327.0 & S. $60 \mathrm{~W}$. & $-45^{\circ}$ & 35.0 & 99.3 \\
\hline Ha-2 & 2 & 275.0 & N. $77^{\circ}$ E。 & $-45^{\circ}$ & 91.0 & 99.3 \\
\hline $\mathrm{Ha}-3$ & 1 & 283.0 & N. $44^{\circ} \mathrm{E}$. & $-45^{\circ}$ & 23.3 & 97.5 \\
\hline $\mathrm{Ha}-4$ & 3 and 4 & 294.3 & N. $55^{\circ}$ E. & $-45^{\circ}$ & 31.0 & 99.2 \\
\hline $\mathrm{Ha}-5$ & 3 and 4 & 214.8 & N. $55^{\circ} \mathrm{E}$. & $-45^{\circ}$ & 45.0 & 99.4 \\
\hline $\mathrm{Ha}-6$ & 1 and $2(?)$ & 437.5 & N. 410 E。 & $-45^{\circ}$ & 10.0 & 99.5 \\
\hline $\mathrm{Ha}-7$ & 1 & 586.1 & S. $44^{\circ} \mathrm{W}$. & $-45^{\circ}$ & 47.0 & 99.1 \\
\hline $\mathrm{Ha}-8$ & 1 & 200.2 & N. $44^{\circ} \mathrm{E}$. & $-60^{\circ}$ & $4 \cdot 4$ & 9.9 .9 \\
\hline$\cdots \mathrm{Ha}-9$ & 5 & 215.8 & N. $54^{\circ} \mathrm{E}$ & $-45^{\circ}$ & 29.0 & 99.6 \\
\hline $\mathrm{Ha}-10$ & 1 & 248.7 & N. $61^{\circ} \mathrm{W}$. & $-45^{\circ}$ & 65.0 & 100 \\
\hline $\mathrm{Ha}-\mathrm{II}$ & 1 & 210.0 & No $4^{\circ} \mathrm{W}$. & $-45^{\circ}$ & 42.0 & 96.1 \\
\hline
\end{tabular}

If Reported by U. S. Bureau of Mines. Some core recovered above these depths. 
Table 4.--Analyses of samples from prospect pits and surface exposures at Haputa ranch.

Total rare earth

Sample number 1/ Type of sample 2/ Length of sample Equivalent uranium Chemical uranium Equivalent ThO $23 /$ oxides and ThO (feet) (percent) (percent) (percent) (percent)

Chemical $\mathrm{ThO}_{2}$ Possible rare earth oxides

Locality from the vicinity of drill holes Ha-3 and $\mathrm{Ha}-7$

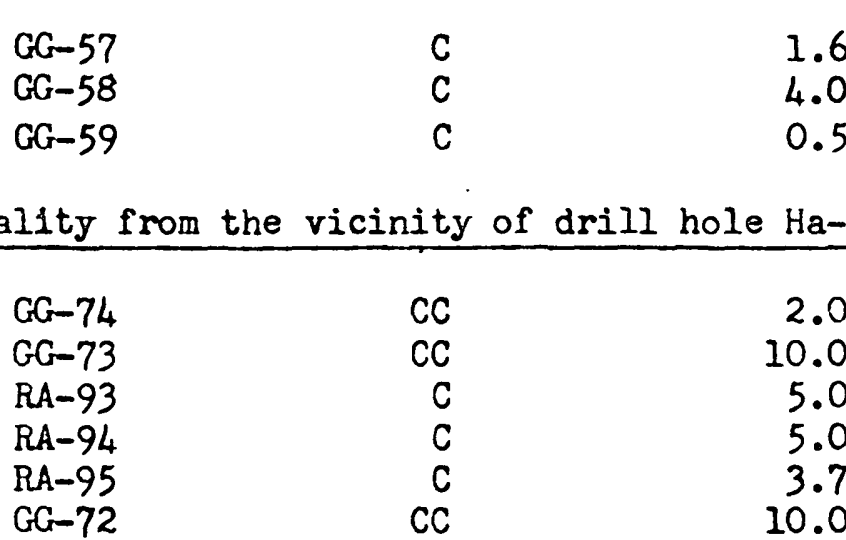

.026

.001

.142
.057
8.08

.32
.31
6.84

.154
.080
2.62
.741
4.62
.148

.001
.001
.001
.001
.009
.001

.027
.015
.46
.13
.81
.027

10.0

.

ocality from the vicinity of drill holes Ha-10, Ha-11 and Ha-6

$\begin{array}{lrrl}\text { GG-70 } & \text { CC } & 25.0 & .016 \\ \text { RA-97 } & \mathrm{C} & 2.0 & .20 \\ \text { RA-96 } & \mathrm{C} & 2.0 & .11 \\ \mathrm{GG}-42 & \mathrm{C} & 1.9 & .22 \\ \mathrm{GG}-43 & \mathrm{C} & 5.0 & .07 \\ \mathrm{GG}-47 & \mathrm{C} & 2.0 & .74 \\ \mathrm{GG}-69 & \mathrm{CC} & 5.0 & .012 \\ \mathrm{GG}-68 & \mathrm{CC} & 12.0 & .012\end{array}$

$\begin{array}{lll}.016 & .001 & .086 \\ .20 & .002 & 1.14 \\ .11 & .001 & .627 \\ .22 & .002 & 1.14 \\ .07 & .001 & .342 \\ .74 & .002 & 4.21 \\ .012 & .001 & .063 \\ .012 & .001 & .063\end{array}$

.148

(percent) 4

locality from the vicinity of drill holes Ha-2 and Ha-l

$\begin{array}{lrrr}G G-75 & C C & 2.0 & \\ G G-48 & C & 1.8 & .038 \\ G G-71 & C C & 3.0 & .007 \\ G G-76 & C & 2.0 & 2.04\end{array}$

Locality from the vicinity of drill hole $\mathrm{Ha}-4$
$G G-55$
$G G-56$
$\begin{array}{rr}\text { CC } & 1.0 \\ \text { CC } & 0.5 \\ C & 0.5\end{array}$
$\begin{array}{ll}1.0 & .068 \\ 0.5 & .014 \\ 0.5 & .012\end{array}$
$\begin{array}{ll}.014 & .001 \\ .001\end{array}$
$\begin{array}{ll}.001 & .382 \\ .001 & .074\end{array}$
$.001-.063$
.001
$\begin{array}{ll}.063 & .39 \\ .382 & .87\end{array}$

$\begin{array}{ll}.33 & .06 \\ .39 & - \\ .87 & -\end{array}$
.32
.81
If Samples listed from north to south along individual shear zones, beginning with shear no. 1. See figure 4 for approximate locations.
2/ $C=$ channel sample; $C C=$ chip channel sample, and $G=$ grab sample
3 Calculated from the equivalent uranium by subtracting the chemical uranium and multiplying by the conversion factor of 5.7 .
4. A minimum figure obtained by subtracting the maximum possible $\mathrm{ThO}_{2}$ (chemical or equivalent) from the chemical percent of total rare earth oxides and $\mathrm{ThO}_{2}$.

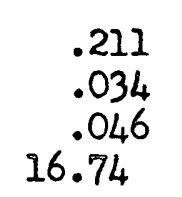

211
.034
.046

.001
.001
.001

16.74

$\begin{array}{lr}.086 & .21 \\ .14 & 2.71 \\ .627 & .95 \\ .14 & 1.11 \\ .342 & .19 \\ .21 & 3.19 \\ .063 & .27 \\ .063 & .23\end{array}$

.06

.18
.25

25

$\begin{array}{ll}.007 & .001 \\ .009 & .001 \\ .94 & .00\end{array}$


Table 4.--Analyses of samples from prospect pits and surface exposures at Haputa ranch-Continued.

Sample number 1/ Type of sample 2/ Length of sample Equivalent uranium Chemical uranium Equivalent ThO 32 Total rare earth Sample number $1 /$ Type of sample $2 /$ Lengt

$$
\text { (feet) }
$$
(percent) (percent) (percent)
Chemical ThO (percent)

Possible rare earth oxides

Locality from the vicinity of drill hole Ha-5

$\begin{array}{lll}G G-52 & C & 1.8 \\ G G-53 & C & 2.25 \\ G G-54 & C & .05 \\ G G-65 & C & 1.0 \\ G G-66 & C & 1.3\end{array}$

.007
.01
.027
.025
.007

$\begin{array}{ll}.001 & .034 \\ .001 & .051 \\ .001 & .148 \\ .001 & .142 \\ .001 & .034\end{array}$

.51
.44
.20
.39
.40

$\overline{-}$

.10

.034

.

.48
.39
.05
.25
.37

Locality from the vicinity of drill hole Ha-?

$\begin{array}{lll}I D-16 & C & 4.0 \\ L D-18 & G & 7 \times 2 \text { zone } \\ L D-20 & G & 2 \times 3 \text { zone } \\ L D-17 & G & \text { Dump. } \\ L D-19 & G & 8.0\end{array}$

Dump.

8.0

$\begin{array}{ll}.008 & .001 \\ .020 & .001 \\ .016 & .001 \\ .007 & .002 \\ .005 & .001\end{array}$

.040
.108
.085
.028
.023

$\overline{-}$

$\overline{5}$ 
Table5. --Analyses of diamond drill cores, samples from the holes at Haputa ranch, Custer County, Colorado

\begin{tabular}{|c|c|c|c|c|c|c|c|c|c|c|c|c|c|c|c|c|c|}
\hline Field & 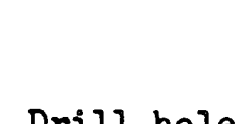 & Depth & Length of sample & $\begin{array}{l}\text { Corrected sample } \\
\text { length } 1\end{array}$ & Equivalent uranium & $\begin{array}{l}\text { Chemical , } \\
\text { uranium }\end{array}$ & Equival ent $\mathrm{ThO}_{2} 2 \mathrm{~J}$ & Chemical $\mathrm{ThO}_{2}$ & Radiochemical $\mathrm{ThO}_{2} 3$ / & $\bar{x}$ & 8 & Spect & graphic & analyse: & $\Gamma^{2}$ & 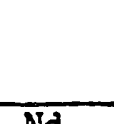 & 7 \\
\hline & & & & & & & & & & & & & & & & & \\
\hline AH -5 & $\mathrm{Ha}-2$ & $171.1-176.9$ & 5.8 & 4.1 & 0.021 & 0.002 & 0.11 & 0.10 & & & & & & & & & \\
\hline $\begin{array}{l}\mathrm{AH}-5 \mathrm{a} \\
\mathrm{AH}-6\end{array}$ & $\begin{array}{ll}\mathrm{Ha}-2 \\
\mathrm{HaO}\end{array}$ & $175.9-176.9$ & 1.0 & .7 & 0.052 & 0.001 & 0.29 & 0.26 & & & & & & & & & \\
\hline $\begin{array}{l}\text { AH }-6 \\
\text { AH-7 }\end{array}$ & $\begin{array}{l}\mathrm{Ha}-2 \\
\mathrm{Ha}-2\end{array}$ & $\begin{array}{l}188.0-188.3 \\
230.6-231.4 \text { and }\end{array}$ & & & 0.007 & & 0.05 & - & & & & & & & & & \\
\hline & & $231.8-232.0$ & 1.4 & 1.0 & 0.005 & 0.001 & 0.02 & - & & & & & & & & & \\
\hline $\mathrm{AH}-8$ & $\mathrm{Ha}-3$ & $233.0-236.4$ & 3.4 & 2.4 & 0.010 & 0.001 & 0.05 & & & & & & & & & & \\
\hline $\begin{array}{l}\text { AH-9 } \\
\text { AH-10 }\end{array}$ & $\begin{array}{l}\mathrm{Ha}-3 \\
\mathrm{Ha}-3\end{array}$ & $\begin{array}{l}236.4-238.4 \\
238.4=230.4\end{array}$ & 2.0 & 1.4 & 0.078 & $\begin{array}{ll}0.001 \\
0.01\end{array}$ & 0.44 & 0.03 & &.$x$ &.$x$ & $.0 x$ & $.00 x$ & $.00 x$ & - & - & $.00 x$ \\
\hline AH -11 & $\begin{array}{ll}\mathrm{Ha}-3 \\
\mathrm{Ha}-3\end{array}$ & $\begin{array}{l}230.4-239.4 \\
239.4-220.5\end{array}$ & 1.0 & $\begin{array}{l}.7 \\
.8\end{array}$ & 0.016 & 0.001 & 0.02 & $=$ & & $.0 x$ & $x$ & $.0 x$ & $.00 x$ & $.00 x$ & - & - & $.00 x$ \\
\hline Ah-12 & $\mathrm{Ha}-3$ & $240.5-241.6$ & \pm .1 & & 0.008 & 0.000 & 0.05 & - & & & & & & & & & \\
\hline $\mathrm{AH}-13$ & $\mathrm{Ha}-3$ & $\begin{array}{l}243.6-242.0 \text { and } \\
242.8-225.2\end{array}$ & 2.8 & 2.0 & 0.005 & 0,000 & 0.03 & - & & 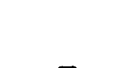 & $\boldsymbol{r}$ & or & 0000 & 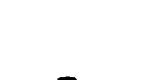 & 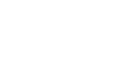 & 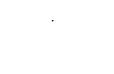 & 500 \\
\hline AH-14 & $\mathrm{Ha}-3$ & $242.0-242.8$ & .8 & 2.0 & 0.008 & 0.000 & $\begin{array}{l}0.03 \\
0.05\end{array}$ & - & & - & & $.0 x$ & $.000 x$ & - & - & - & $.00 x$ \\
\hline $\begin{array}{l}\text { AH-15 } \\
\text { AH-16 }\end{array}$ & $\begin{array}{l}\mathrm{Ha}-3 \\
\mathrm{Ha}-3\end{array}$ & $\begin{array}{l}245.2=247.0 \\
247.0=248.9\end{array}$ & $\begin{array}{l}1.8 \\
1.9\end{array}$ & 1.3 & 0.086 & 0.001 & 0.48 & 0.19 & &.$x$ & $\cdot x$ & $.0 x$ & $.00 x$ & - & - & - & $.0 x$ \\
\hline AH-17 & $\mathrm{HO}_{0}-3$ & & h & 2 & 0008 & $0 m$ & 0 & 00 & & & & 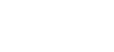 & & & & & \\
\hline AH -18 & $\mathrm{Ha}-3$ & $\begin{array}{l}248.9-249.3 \\
249.3-25.0\end{array}$ & .4 & $1^{3}$ & $\begin{array}{l}0.028 \\
0.008\end{array}$ & $\begin{array}{l}0.000 \\
0.001\end{array}$ & 0.16 & 0.03 & & $.0 x$ & $\cdot x$ & $.0 x$ & .00x & - & - & - & $.0 x$ \\
\hline $\mathrm{AH}-19$ & $\mathrm{Ha}-3$ & $251.0-251.5$ & $\begin{array}{l}1.1 \\
.5\end{array}$ & .4 & 0.28 & 0.001 & $\begin{array}{l}.04 \\
1.59\end{array}$ & 1.43 & & x. &.$x$ &.$x$ & $.0 x$ & $.0 x$ & $.0 x$ & $-x$ &.$x$ \\
\hline $\mathrm{AH}-2 \mathrm{O}$ & $\mathrm{Ha}-3$ & $251.5-253.1$ & 1.6 & 1.1 & 0.026 & 0.001 & 0.14 & & & & & & & & & & \\
\hline$A H-21$ & $\mathrm{Ha}-3$ & $253.1-255.6$ & 2.5 & $\begin{array}{l}1.1 \\
1.8\end{array}$ & 0.008 & 0.001 & $\begin{array}{l}.14 \\
0.04\end{array}$ & 0.02 & & - & $x$ & $.0 x$ & $.000 x$ & - & - & - & $000 x$ \\
\hline AH-22 & $\mathrm{Ha}-3$ & $255.6-256.3$ & .7 & .0 & 0.092 & 0.000 & $\begin{array}{l}0.04 \\
0.52\end{array}$ & 0.16 & & - & & & & & & & $.000 x$ \\
\hline $\mathrm{AH}-23$ & $\mathrm{Ha}-3$ & $256.3-257.5$ & 1.2 & .8 & 0.018 & 0.000 & 0.10 & -10 & & $.0 x$ &.$x$ & $.0 x$ & $.00 x$ & - & - & - &.$\infty 0 x$ \\
\hline & & $\begin{array}{l}257.5=259.0 \text { and } \\
259.3-259.9\end{array}$ & 2.1 & 1.5 & 0.005 & 0.000 & 0.03 & - & & & & & & & & & \\
\hline $\begin{array}{l}\mathrm{AH}-25 \\
\mathrm{AH}-26\end{array}$ & $\begin{array}{l}\mathrm{Ha}-3 \\
\mathrm{Ha}-3\end{array}$ & $\begin{array}{l}259.0-259.3 \\
259.9-2620\end{array}$ & .3 & .2 & 0.15 & 0.000 & 0.86 & 0.04 & &.$x$ &.$x$ & $.0 x$ & $.00 x$ & $.00 x$ & - & - & $.0 x$ \\
\hline AH -27 & $\begin{array}{ll}\mathrm{Ha}-3 \\
\mathrm{Ha}-3\end{array}$ & $262.0-264.0$ & $\begin{array}{l}2.1 \\
2.0\end{array}$ & 1.5 & 0.11 & 0.000 & 0.63 & 0.10 & & & & & & & & & \\
\hline $\mathrm{AH}-2$ & $\mathrm{Ha}-3$ & $264.0-265.8$ & 1.8 & 1.3 & 0.052 & 0.00 & $\begin{array}{l}.57 \\
0.30\end{array}$ & 0.04 & & ex & $\cdot x$ & $.0 x$ & $.00 x$ & $.00 x$ & - & - & $.0 x$ \\
\hline & $\mathrm{Ha}-3$ & $265.8-270.0$ & 4.2 & 3.0 & 0.063 & 0.001 & 0.35 & 0.03 & & . $x$ & $.0 x$ & $.0 x$ & $.00 x$ & - & - & - &.$x$ \\
\hline AH -30 & & $270.0-270.5$ & .5 & .4 & 0.006 & 0.000 & 0.03 & - & & •x & $.0 x$ & & & & & & \\
\hline AH-31 & $\mathrm{Ha}-4$ & $165.6-167.2$ & 1.6 & 1.1 & 0.004 & 0.000 & 0.02 & - & & & & & & & & & \\
\hline $\begin{array}{l}\mathrm{AH}-32 \\
A \mathrm{H}-33\end{array}$ & $\begin{array}{l}\mathrm{Ha}-4 \\
\mathrm{Ha}-\mathrm{L}\end{array}$ & $167.2-168.9$ & 1.7 & 1.2 & 0.004 & 0.000 & 0.02 & - & & & & & & & & & \\
\hline $\begin{array}{l}A H-33 \\
\text { AH }-34\end{array}$ & $\begin{array}{l}\begin{array}{l}\mathrm{a}-4 \\
\mathrm{Ha}-4\end{array} \\
\text { (n) }\end{array}$ & $\begin{array}{l}170.1-170.5- \\
249.0-249.9-\end{array}$ & .4 & .3 & 0.003 & 0.000 & 0.02 & - & & & & & & & & & \\
\hline 然 -55 & 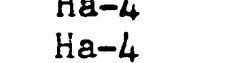 & $\begin{array}{l}244.0-249.9 \\
253.1-253.5\end{array}$ & .9 & .6 & 0.003 & 0.000 & 0.02 & - & & & & & & & & & \\
\hline
\end{tabular}

1/ As the Holes were drilled at angles of $45^{\circ}$ or $60^{\circ}$, therefore, the sample lengths have been corrected to give the true width across the vei $n$,

2/ Calculated from the equivalent uranium by subtracting the chemical uranium and multiplying by the conversion factor of 5.7.

3) A method of analysis in which the radioactive material is separated chemically and determined radiometrically. 
Table 5.--Analyses of diemond drill cores, samples from the holes at Haputa ranch, Custer County, Colorador-Continued.

\begin{tabular}{|c|c|c|c|c|c|c|c|c|c|c|c|c|c|c|c|c|}
\hline $\begin{array}{l}\begin{array}{l}\text { Pield } \\
\text { number }\end{array} \\
\text { un }\end{array}$ & Drill hole & $\begin{array}{c}\text { Depth } \\
\text { (feet) }\end{array}$ & $\begin{array}{c}\text { Length of sample } \\
\text { (feet) }\end{array}$ & $\begin{array}{l}\text { Corrected sample } \\
\text { leneth } 1 / \text { s) } \\
\text { (feet) }\end{array}$ & $\begin{array}{l}\text { Equival ent uraniorm } \\
\text { (percent) }\end{array}$ & $\begin{array}{l}\text { Chemical } \\
\text { uranium } \\
\text { (percent) }\end{array}$ & $\begin{array}{c}\text { Equivelent } \operatorname{Tho}_{2} 2 / 1 \\
\text { (percent) }\end{array}$ & $\begin{array}{c}\text { Chemical } \mathrm{ThO}_{2} \\
\text { (percent) }\end{array}$ & $\begin{array}{c}\text { Radiochemical } \\
\text { (percent) }\end{array} \mathrm{ThO}_{2} 3 /$ & $\overline{\mathrm{T}_{\mathrm{n}}}$ & $\mathrm{Ba}$ & $\begin{array}{l}\text { Spect. } \\
\text { Sr }\end{array}$ & ographi & $\frac{\text { analyses }}{\mathrm{L} \text { L } \quad \mathrm{Ce}}$ & $\mathbb{N d}$ & $Y$ \\
\hline $\begin{array}{l}\text { AH-36 } \\
\text { AH-37 } \\
\text { AH-38 } \\
\text { AH-39 }\end{array}$ & $\begin{array}{l}\mathrm{Ha}-5 \\
\mathrm{Ha}-5 \\
\mathrm{Ha}-5 \\
\mathrm{Ha}-5\end{array}$ & $\begin{array}{l}147.4-148.2 \\
189.9-190.4 \\
191.6=191.9 \\
192.8-193.4\end{array}$ & $\begin{array}{l}.8 \\
.5 \\
.3 \\
.6\end{array}$ & $\begin{array}{l}.6 \\
. .4 \\
.2 \\
.4\end{array}$ & $\begin{array}{l}0.006 \\
0.009 \\
0.004 \\
0.012\end{array}$ & $\begin{array}{l}0.001 \\
0.000 \\
0.000 \\
0.001\end{array}$ & $\begin{array}{l}0.03 \\
0.05 \\
0.02 \\
0.06\end{array}$ & $\vdots$ & & $.0 x$ &.$x$ & $\cdot x$ & $.00 x$ & $.00 x-$ & - & .ox \\
\hline $\begin{array}{l}\text { AH- } 44 \\
\text { AH- } 45 \\
\text { A- } 46 \\
\text { AH- } 47 \\
\text { AH- } 48\end{array}$ & $\begin{array}{l}\mathrm{Ha}-6 \\
\mathrm{Ha}-6 \\
\mathrm{Ha}-6 \\
\mathrm{Ha}-6 \\
\mathrm{Ha}-6\end{array}$ & 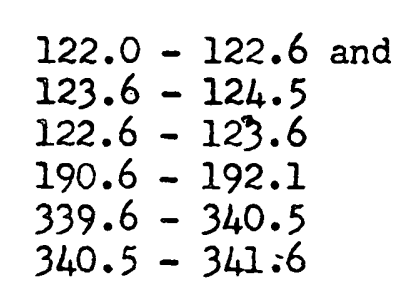 & $\begin{array}{l}1.5 \\
1.0 \\
1.5 \\
.9 \\
1.1\end{array}$ & $\begin{array}{r}1.1 \\
.7 \\
1.1 \\
.6 \\
.8\end{array}$ & $\begin{array}{l}0.009 \\
0.044 \\
0.010 \\
0.043 \\
0.013\end{array}$ & $\begin{array}{l}0.001 \\
0.001 \\
0.001 \\
0.001 \\
0.001\end{array}$ & $\begin{array}{l}0.05 \\
0.24 \\
0.05 \\
0.24 \\
0.07\end{array}$ & $\begin{array}{l}0.25 \\
0.06 \\
-\end{array}$ & & & & & & & & \\
\hline $\begin{array}{l}\text { AH- } 40 \\
\text { Al- } 41 \\
\text { Al- } 42 \\
A-43\end{array}$ & $\begin{array}{l}\mathrm{Ha}-7 \\
\text { Ha-7 } \\
\text { Ha-7 } \\
\text { Ha-7 }\end{array}$ & $\begin{array}{l}495.3-497.5 \\
497.5=48.5 \\
500.8-502.2 \\
505.7-506.7\end{array}$ & $\begin{array}{l}2.2 \\
.7 \\
1.6 \\
1.0\end{array}$ & $\begin{array}{r}1.6 \\
.5 \\
1.1 \\
.7\end{array}$ & $\begin{array}{l}0.044 \\
0.006 \\
0.042 \\
0.009\end{array}$ & $\begin{array}{l}0.001 \\
0.001 \\
0.0001 \\
0.001\end{array}$ & $\begin{array}{l}0.24 \\
0.03 \\
0.23 \\
0.05\end{array}$ & $\begin{array}{l}0.21 \\
0.15 \\
-\end{array}$ & & $\begin{array}{l}. x \\
-. x\end{array}$ & $\begin{array}{l}.0 x \\
.0 x \\
.0 x \\
. x\end{array}$ & $\begin{array}{l}.0 x \\
.0 x \\
.0 x \\
.0 x\end{array}$ & $\begin{array}{l}.000 x \\
.000 x \\
.000 x \\
.00 x\end{array}$ & $\bar{z}$ & $\bar{z}$ & $\begin{array}{l}.00 x \\
.000 x \\
.00 x \\
.000 x\end{array}$ \\
\hline $\begin{array}{l}\text { AH-49 } \\
\text { AH-50 } \\
\text { AH-51 } \\
\text { AH-52 } \\
\text { AH-53 } \\
\text { AH-54 }\end{array}$ & $\begin{array}{l}\mathrm{Ha}-8 \\
\text { Ha-8 } \\
\text { Ha-8 } \\
\text { Ha-8 } \\
\text { Ha-8 } \\
\text { Ha-8 }\end{array}$ & $\begin{array}{l}139.2=140.4 \\
140.7=141.8 \\
1433.7=174.3 \\
1147.3=149.7 \\
1499.7=150.4 \\
150.4=151.8\end{array}$ & $\begin{array}{l}1.2 \\
1.1 \\
3.6 \\
2.4 \\
.7 \\
1.4\end{array}$ & $\begin{array}{r}.7 \\
.7 \\
2.2 \\
1.4 \\
.4 \\
.8\end{array}$ & $\begin{array}{l}0.13 \\
0.136 \\
0.036 \\
0.097 \\
0.040 \\
0.29 \\
0.032\end{array}$ & $\begin{array}{l}0.002 \\
0.001 \\
0.001 \\
0.001 \\
0.005 \\
0.001\end{array}$ & $\begin{array}{l}0.73 \\
0.20 \\
0.55 \\
0.22 \\
1.62 \\
0.18\end{array}$ & $\begin{array}{l}0.53 \\
0.28 \\
0.19 \\
0.12 \\
1.78 \\
0.01\end{array}$ & $\begin{array}{l}0.76 \\
0.53\end{array}$ & $\begin{array}{c}. x \\
. x \\
. x \\
. x \\
x .0 \\
.0 x\end{array}$ & $\begin{array}{l}. x \\
: x \\
: x \\
. x \\
. x \\
.0 x\end{array}$ & $\begin{array}{l}.0 x \\
.0 x \\
.0 x \\
.0 x \\
.0 x \\
.0 x\end{array}$ & $\begin{array}{l}.0 x \\
.00 x \\
.0 x \\
.000 x \\
.00 x \\
.0 x\end{array}$ & 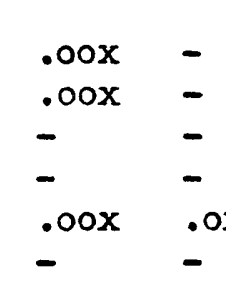 & $\bar{z}$ & $\begin{array}{l}.0 x \\
.0 x \\
. x \\
.0 x \\
. x \\
.0 x\end{array}$ \\
\hline
\end{tabular}


Diagrammatic logs of the drill holes are given in figures 5 to $U_{4}$. The

counts per minute (CPM) are given on a logarithmic scale in order to condense the length of the higher peaks. They show a good correlation between the radioactivity and the geology logged in the core of the drill holes.

Drill holes Nose $\mathrm{Ha}-3$ and. Ha-7.-Economically, drill holes $\mathrm{Ha}-3$ and $\mathrm{Ha}-7$ are the most important holes drilled at Haputa Ranch; hole Ham 3 revealed an ore zone about 26 feet thick at a depth of 200 feet and Ha-7 showed that this same zone continues to a depth of 400 feet where it is more weakly radioactive. The drill holes, which axe approximately in the same plane, cut the northwest part of shear zone No. 1 beneath a 20 moot shaft (fig. 4 ).

Log of drill holes Nos. $\mathrm{Ha}-3$ and $\mathrm{Ha}-7$

Hole No. $\mathrm{Ha}-3$

0.0-54.2 Migmatite. Largely microcline granite

54.2-55.0 Amphibolite

55.0-63.1 Migmatite. Highly fractured and limonite-stained in lower part

63.1-104.6 Basic dike rock containing hornblende phenocrysts and aphanitic chilled border

104.6-233.0 Migmatite. Small percentage of microcline granite. Slightly mineralized at contact with basic dike rock

$233.0-270.5$ Hydrothermal vein material

232.4-236.4 Weak radioactivity

$236.4-239.8$ Strong radioactivity

$239.8 \times 245.0$ Weak radioactivity

$245.0-254.0$. Strong radioactivity

254.0-259.0 Moderate radioactivity

259.0-270.5 Strong radioactivity

270.5-277.0 Basic dike rock. Aphanitic

277.0-283.0 Migmatite (g). Pegmatite and amphibolite

$$
\text { Hole No. } \mathrm{Ha}-7
$$

0.0-373.0 Migmatite with much amphibolite, minor pegmatite and minor microcline granite

373.0-377.0 Fine-grained dark red microcline granite

377.0-394.5 Migmatite

394.5-396.0 Dark red microcline granite

396.0-448.8 Migmatite, slightly mineralized at 446.5-448.1

448.8-470.0 Basic dike rock containing small hornblende phenocrysts 
470.0 0 479.0 Basic dike rock and granite, slightly altered 479.0-492.2 Migmatite and amphibolite

492.2.518.4 Hydrothermal vein material and microcline granite

$518.4-527.0$ Basic dike rock. Aphanitic

527.0-586.1 Amphibolite, biotite granite gneiss, and migmatite

The rocks which are exposed on the surface in this area are principally migmatite and microcline gxanite. The coarse-grained facies of the alaskitic granite occurs both in the migmatite and in separate masses. Most of the rock cut in the drill holes is migmatite; the rock in the upper part of the holes more closely resembles microcline granite and in the lower part biotite granite gnelss. Holo Ha-7 also cut considerable amounts of fine-grained amphibolite. In both drill holes basic dike rock was adjacent to the radioactive zone.

The vein consists of barite, quartz, limonite, and variable amounts of the thorite. The radioactive zone in the shaft is about 6 feet thick and con tains 0.1 to 8.1 percent equivalent $\mathrm{ThO}_{2}, 0.001$ to 0.002 percent uranium, and as much as 0.26 percent rare-earth oxides (table 4).

The shear zone has a nearly vertical dip (fig. 5 in envelope). At the surface It is about ten feet thick including the basic dike; at a depth of 200 feet it is 30 feet thick; and at a depth of 400 feet it is 25 feet thick. Between the 2000 foot and the 400-foot levels the aphanitic basic dike in shear zone no. I shifts sides; at 200 feet it is on the northeast side of the mineralization and at 400 feet it is on the southwest side.

The results of Barnaby logging indicated that the entire width of the shear zone in the drill hole ( 37.4 feet) is very radioactive; portions cono tain as much as 1.5 percent equivalent $\mathrm{ThO}_{2}$. The equivalent $\mathrm{ThO}_{2}$, calculated from the equivalent uranium values, range from a trace to 1.6 percent: the estimated percentages of equivalent $\mathrm{ThO}_{2}$ based on the gamme-ray logs are higher. The radioactivity of the shear zone cut in hole $\mathrm{Ha}_{-7} 7$ is lower than that is hole Ha-3. Two samples, 1.6 feet and 1.1 feet long, contained from a trace 
to 0.2 percent equivalent $\mathrm{ThO}_{2}$. The gamma-ray logs showed that the entire zose is weakly to moderately radioactive. The comparative weakness of the radioactivity in hole Ham does not preclude the possibility of highermgrade ore extending to or below this level, inasmuch as the ore is known to have an irregular distribution within the shear zone. As the shear zone is strong at the 400-foot level, the possibllity of the thorium deposit continuing to depth with additional highograde ore is good.

Dxill hole No. Ha-8 $-\infty$ Drill hole Ha-8 (fig. 6) explored shear zone No. I, 800 feet southeast of holes $\mathrm{Ha}-3$ and $\mathrm{Ha}-7$, and 640 feet northwest of hole Ha-6. This hole was drilled under a small, but strong, radiometric anomaly (fig. 4), located by use of the gamma scintillation detector. The two surface exposures of the vein were mineralized granite that contained 0.1 and 0.2 percent equivalent $\mathrm{ThO}_{2}$ (samples $\mathrm{GG}-74$ and $\mathrm{GG}-73$, table 4). Bulldozing revealed a vein zone In fractured granite about five feet thick. Samples RA-93 and RA-94 (table 4). wer taken two feet apart across the mineralized vein and RA-95 was taken across the most radioactive part of the vein. They contained $2.6,0.74$, and 4.6 percent equivalent $\mathrm{ThO}_{2}$ respectively. The thorium minerals are spotty: aggregates of the thoriumbearing material occur irregularly along fractures is the mineralized granite. No gangue minerals are present.

A sample (GG-72) from an outcrop of the shear zone, 270 feet to the sortheast, assayed 1.5 percent equivalent $\mathrm{ThO}_{2}$.

The drill hole No. Ha-8 was in biotite granite gneiss and minor microo cline granite over most of its length; the remainder was mineralized shear zone and the basic dike. A generalized log of the core for this hole is given below: 
DY̊I hole No. Ha-8

0.0.81.0 Blotite grante gneiss cut by occasional smaII dires and stroingers of microcine granito and a sou ampho bollite stringeros

81.0-82.5 Cossisemgraed microclino granito

$82.5-114.0$ Blotite greanite gneise

136.0.125.2 Granite. Fractures coated with hematite, slightly radiosetiva

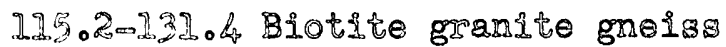

13 II.4-139.2 Biotite granite gneisa, Elightly reddensd by hydroo thormal mineralization

-192.5 Fracturso filled with 1/16 inch or thor 1 to

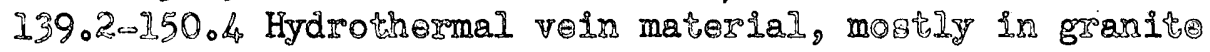

$150.4-152$. of Fydrothermal vein material, mostis In amphibolit

$152.7-159.2$ Hydrothermalfy altered mixiure of rsactured granite and amphibolite

159.2. 269.0 Basic dike rock, cut by two hydrothermal veins

169.0-270.3 Mineralized and altered biotite granite gnelse

$170.3-200.2$ Biotite granite gneiss cut by younger granite at 173 to 178.6 and 182.4 to 191.2

The nome radiaretro part of the shear zone is 6 feet thick at the

sirporace and 10 feet at a depth of 130 feet, If the basic dike is included ar part of the shors zone, the zone is 25 reot thick at, the surface and 13

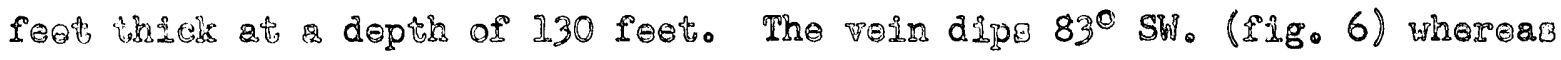
the basie diss dips $860 \mathrm{NE}$. At a depth of 130 feet and ors the surfece, the

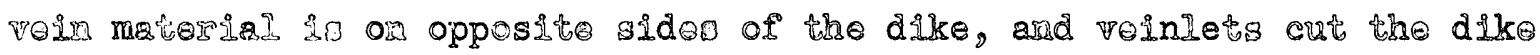
In the core, the indicating that the vein crossed the duke above the 130 foot

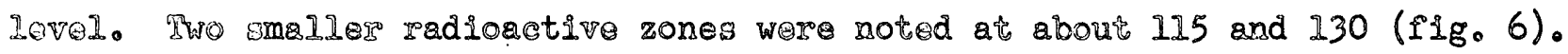

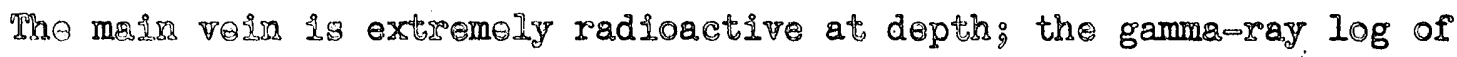
hole Ha shows the highest radometrie reading rocordad ins the Haprta Ranch

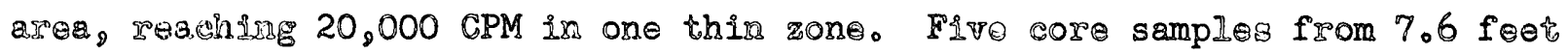
of vein contalsed 0.2 to 1.6 percent equivalent ThO $2_{2}^{\circ}$

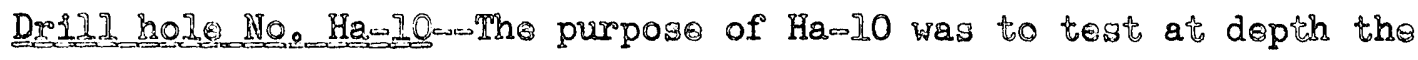
extremely radioactive part of shear zones Nom. 1 and 2 about 100 feet northwest or hole Ha-b. Dellwig had sampled two strongly radioactive aseas, one to the noweth of the drill hole Ha-10 (sample GGaro) and assothers to the south 


\section{EXPLANATION}

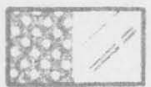

Vein and veinlets

(in sheor zones)

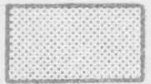

Bosic dike rock

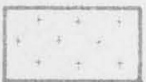

Microclire granite

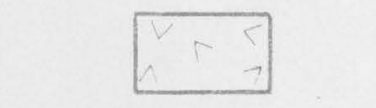

Biotite granite gneiss

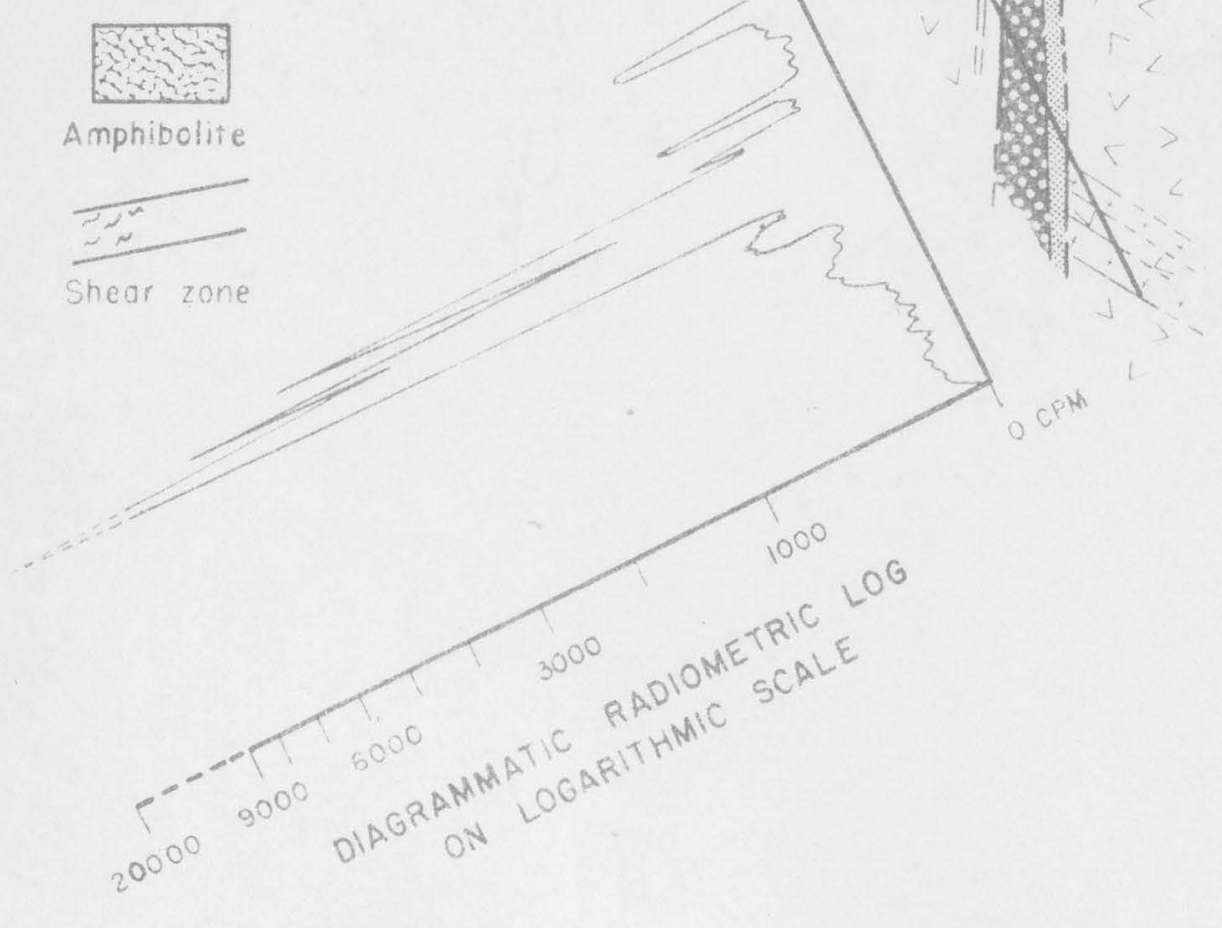

COLLAR ELEVATION

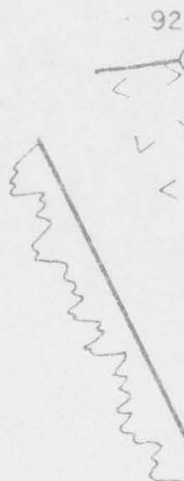

234.5

\section{(1)}
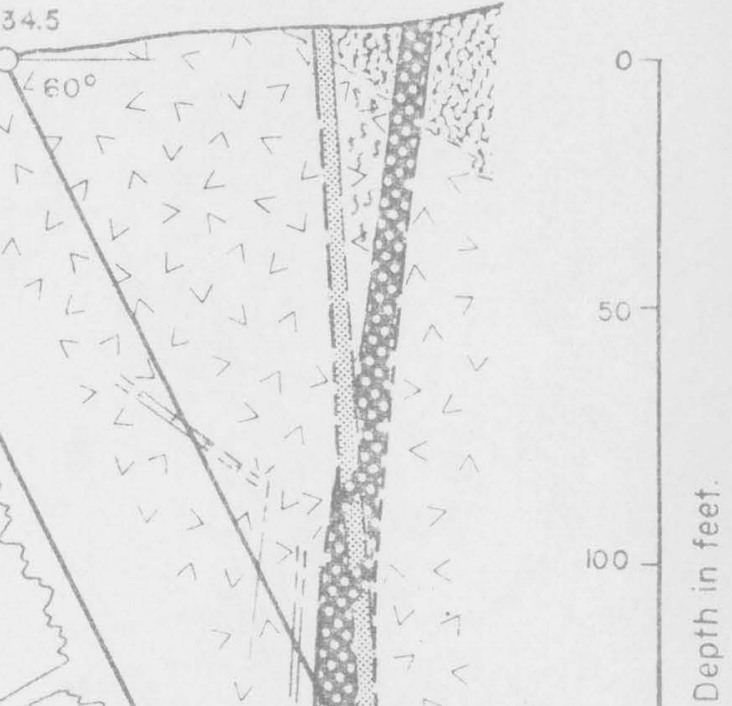

\section{Biotite}

200

FIGURE 6. - SECTION THROUGH DRILL HOLE HA-8, CUSTER COUNTY, COLORADO. 
(samples $G G-42,43$, and 47). The scintiliation counter emphasized the abnormality of this part of the shear zones and localized the most radioaetive areas; the readings were among the highest obtained on the Haputa Raneh (fig. 4). The hole cut below the center of the area of high radioactivity. The generalized log is given below.

$$
\text { Log of drill hole No. Ha-10 }
$$

$0.0-31.1$ Migmatite and minor amphibolite

31.1 50.6 Metagabbro, highly weathered in first five feet; fractured and weathered at 44.7 to 50.6

50.6-59.6 No core recovery, probably highly weathered and broken metagabbro

59.6-123.7 Metagabbro, cut locally by pegmatite and white granite

123.7-131.2 Basic dike rock, slightly mineralized

131.2-136.4 Metagabbro

$136.4=137.7$ Hydrothermal vein material, very weakly radioactive

13\%. 7 -182.0 Metagabbro, cut locally by coarse and fine-grained white and salmon colored granite

182.0-183.3 Amphibolite

$183.3-185.6$ Metagabbro

185.6-192.0 Amphibolite, poorly developed gneissic structure

192.0.198.8 Metagabbro

198.8-205.3 Microcline granite

205.3-220.6 Metagabbro

220.6-222.3 Hydrothermal vein material

$222.3-248.7$ Metagabbro

Exposures on the surface were very poor near drill hole Ha-10 at the time of dxilling; later bulldozing revealed that the area was composed of metagabbro with migmatite to the north and a small area of biotite granite gneiss and amphibolite to the south. The vein in the bulldozed trenches is only two feet wide but has high radioactivity. The two foot channel sample ( $\mathrm{RA}-96)$ from the longer trench contained 0.6 percent equivalent $\mathrm{ThO}_{2}$ and the two-foot sample (RA-97) from the smaller trench contained 1.1 percent equivalent $\mathrm{ThO}_{2}$ (table 4).

The dxill hole (fig. 7) did not locate high grade ore at depth below the surface exposure, but as shown on the Barnaby log, a weakly radioactive 


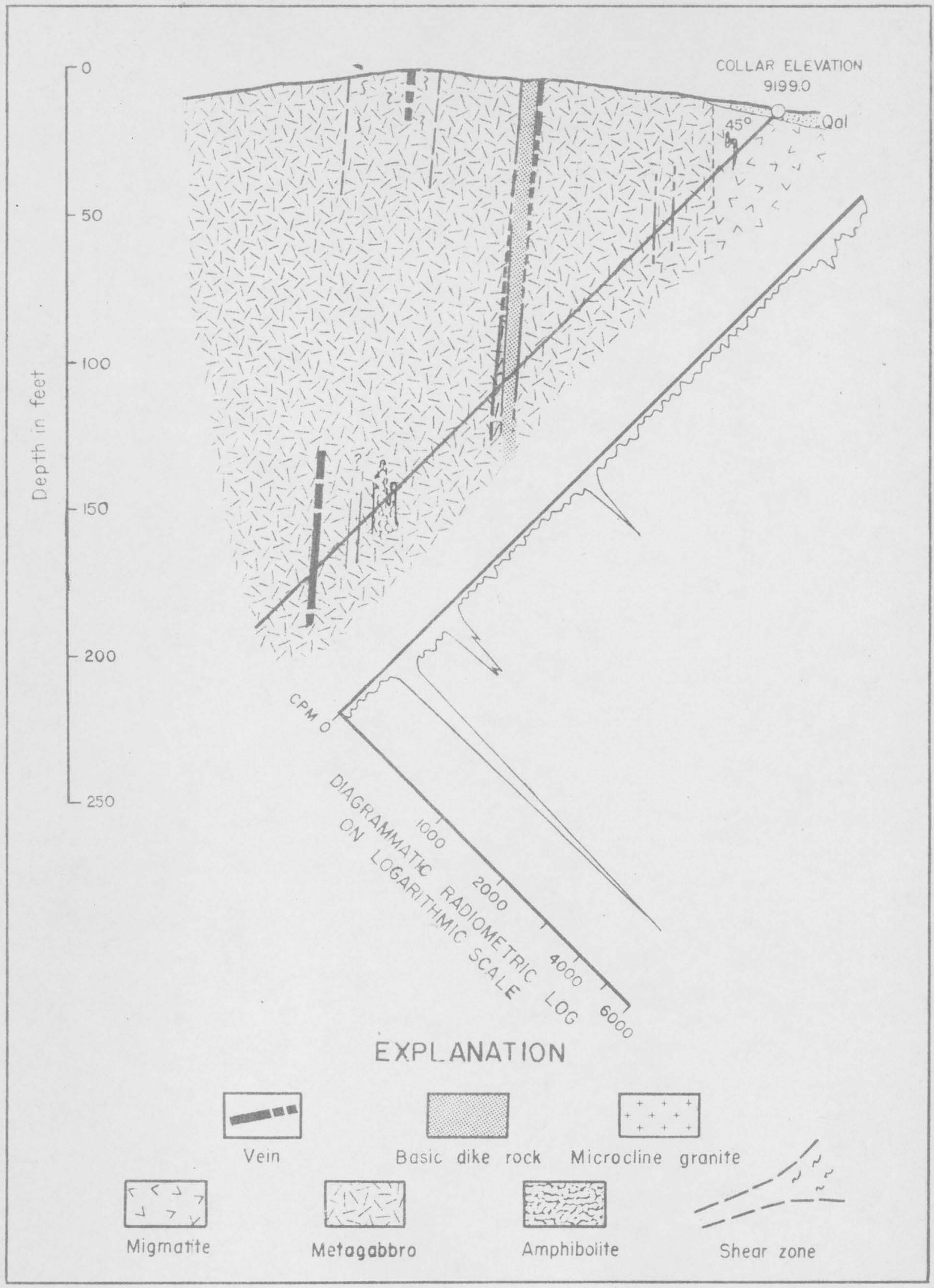

FIGURE 7.-SECTION THROUGH DRILL HOLE HA-IO, CUSTER COUNTY, COLORADO 50 50 Feet 
zone was found on the west side of the basic dike in this shear zone. One anomaly of about the same intensity probably marks the east edge of the shear zone connecting zones nos. $I$ and 2 and a more intense anomaly marks a twow foot radioactive zone near the bottom of the hole at the western margin of the shear zone.

From the position of this drill hole in relation to the 300 -foot long area enclosed by the isorads on the surface (fig. 4), it is unlikely that the ore shoot exposed on surface is continuous in depth.

Drill hole no. Ha-11.--After drill hole Ha-10 failed to find as high grade ore in depth as on surface, drill hole Ha-ll was drilled in an attempt to cut a high grade deposit a short distance to the north. The hole was planned to explore ground beneath one of the most radioactive surface areas, cutting the strike of the shear zone at an angle, so as to be in possible ore ground for a greater drilling length. The strongest radioactivity found in the hole was little more than twice background eliminating the possibility that the high grade body might rake to the north.

The basic dike has an apparent dip of $74^{\circ}$ to the south in the section of the drill hole (fig. 8) and has a true dip of about 780; it probably forms the northeast side of shear zone no. I at the surface. In the drill hole, a fivefoot altered zone is believed to represent a fault contact (west side of shear zone connecting zones nos. $I$ and 2) between the granite and the metagabbro. Between these limits the shear zone is not recognizable in the drill hole.

The gamma-ray log shows that the granitic wall rocks in this hole have. radioactivity of about twice background (fig. 8). The generalized log of the drill core is given below: 


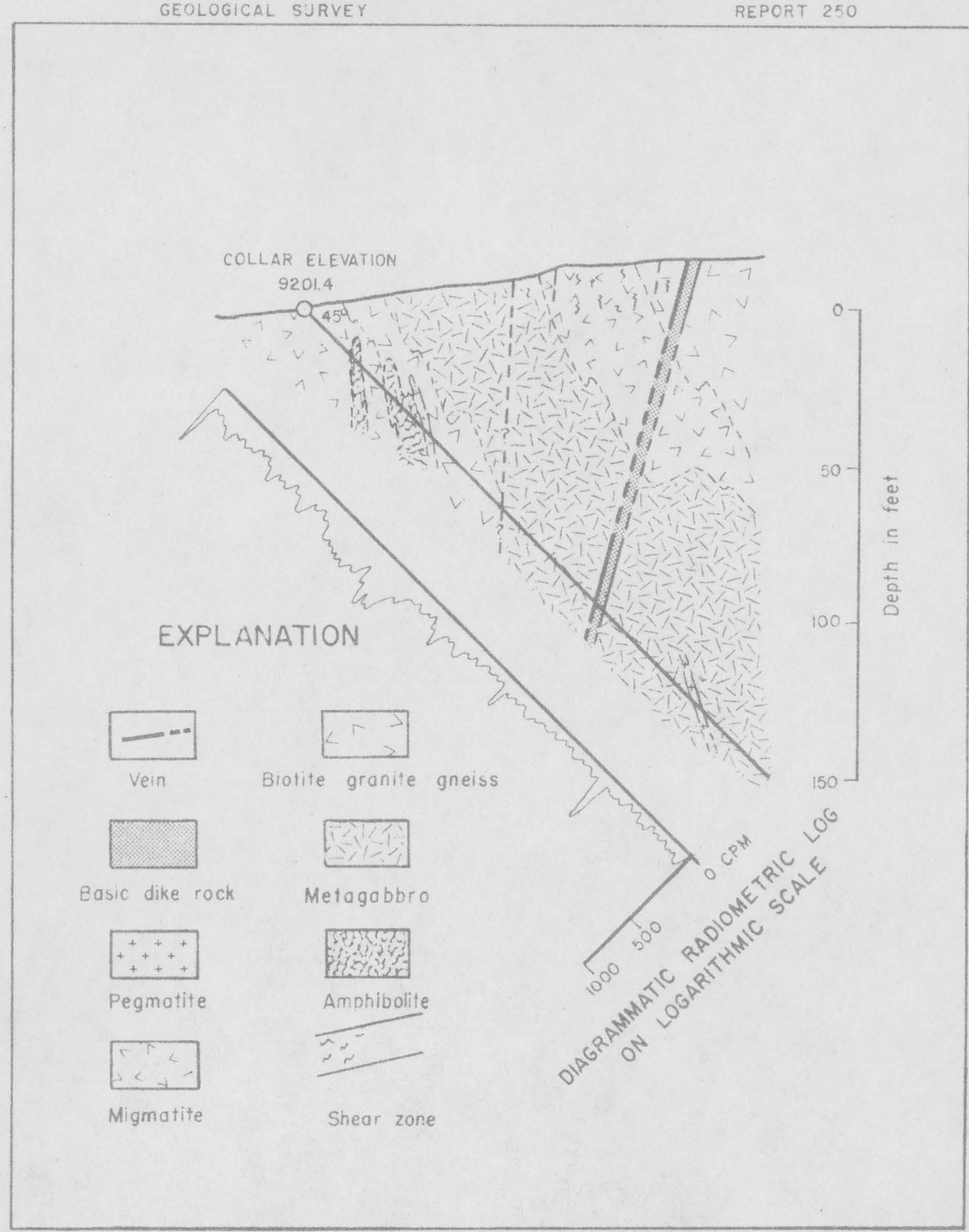

FIGURE 8. - SECTION THROUGH DRILL HOLE HA-II, CUSTER COUNTY, COLORADO

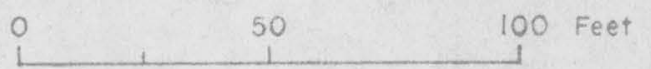


Log of droll hole no. Hacll

$0.0-20.7$ Migmatite and minor amphibolite

$20.7-24.0$ Amphibolite

24.0.35.4 Migmatite and amphibolite, locally highly broken

and limonitemstained

35.4m56.0 Amphibolite, Iocally broken and Iimonitemstained

56.0 .57 .4 White granite stringer

57.4 87.5 Biotite granite gneiss. Some migmatite and amphibolite

85.5.92.4 Completely altered rock, clay (8)

92.4-128.4 Metagabbro. First eight feet are altered

128.4-129.3 Metagabbro cut by hydrothexmal poin material

129.3-131.4 Basie dike roek and minor bydrothermal veinlets

131. 4 w135.5 Basie dike rock

$135.5-174.6$ Metagabbro

174.6-176.8 White granite, coarsemgrained

$176.8-210.1$ Metagabbro

Dril1 hole no Hamb-omill hole Ha-6 extends aeross the shears nos. I

and 2 as ivell as the connecting zone. It is on the south edge of the highly radioạlve zone shown on the scintillation detector; its purpose, in addition to testing for ore, was to determine the nature of the structure in this area where shear zones nos. 1 and 2 appear to split ( $P$ g. hole, whon supplemented by that from the bulldowing and drill holes Ha-10 and Ha-11, shows that the structure consists of several fractures or faults connecting the shear zones nos. I and 2.

About 95 percent of the surface outcrops and the rook cut by the drill are metagabbro; the remainder are granitic dikes asd stringers, pegmatites, and the basie dike rook. The metagabbro in the drill hole is cut by many small veins and veinlet,s of hydrothermal matore? that is slightly radio active (eIg.9). The hydrothermal material is characterized by a red color and appears to be composed of microcline, quartis, and carbonate; it probably formed by replacement along fractures in the metagabbro. 


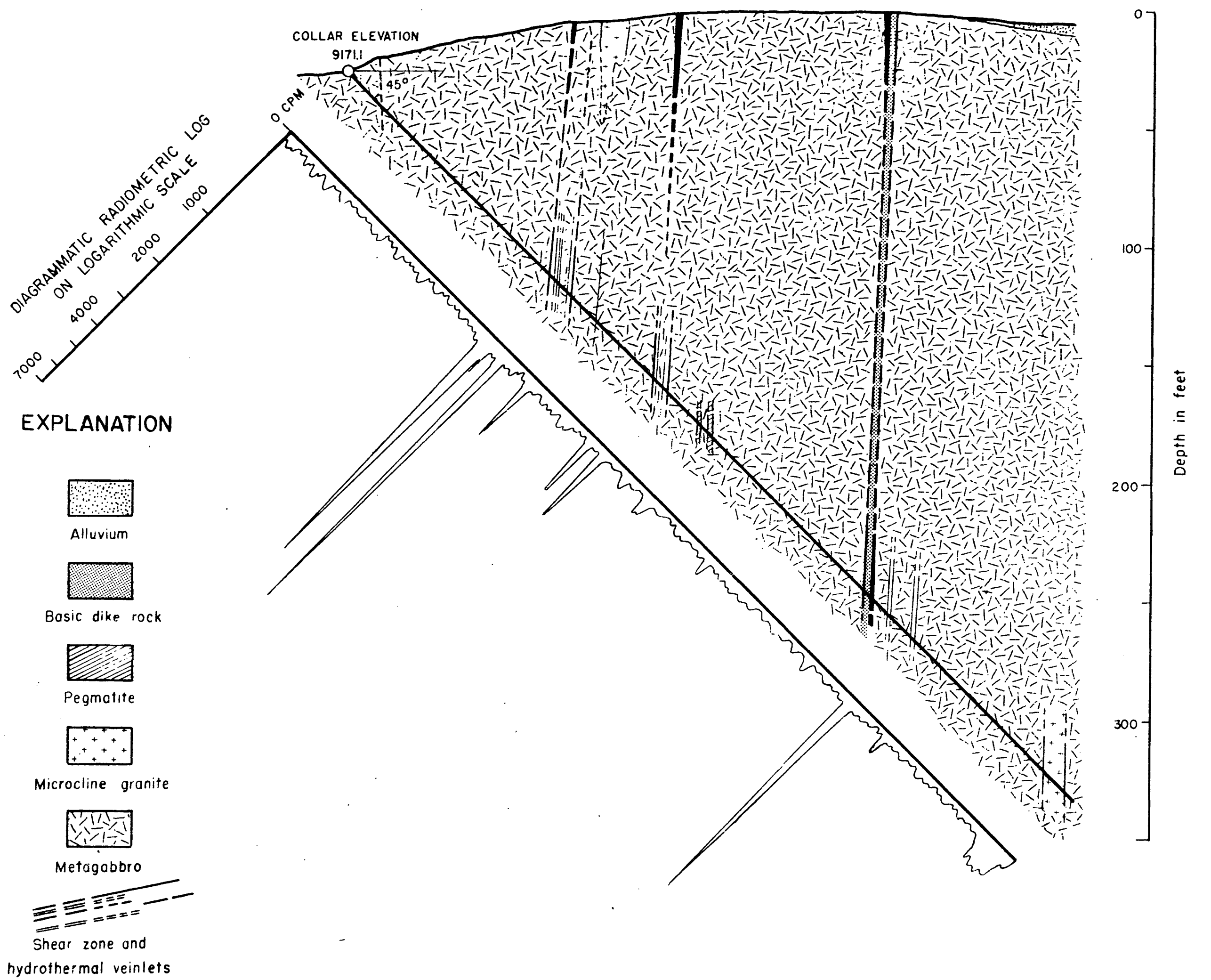

FIGURE 9. - SECTION THROUGH DRILL HOLE HA-6, CUSTER COUNTY, COLORADO $\circ \quad 1 \quad 50 \quad 100$ Feet 
Log of drill hole no. Ha-6

$0.0-18.5$ Metagabbro cut by minor white granite dikes and stringers

18.5 - 19.3 Fractured zone in metagabbro. Possible mineralization

19.3 -120.2 Metagabbro, in part the feldspar-low variety, cut by minor white granite stringers and pegmatite

120.2 -136.5. Metagabbro cut by veinlets of hydrothermal material

$136.5-183.1$ Metagabbro and white granite dikes and stringers

148.5 Two small hydrothermal veinlets

183.1 -194.4 Metagabbro cut by minor hydrothermal material

$194.4-310.6$ Metagabbro and minor white granite

$310.6-315.0$ Basic dike rock

$315.0-345.0$ Metagabbro cut by minor hydrothermal veinlets

$345.0-418.0$ Metagabbro and minor white granite

$418.0-432.2$ Microcline granite, Radioactivity higher than background

$432.2 \times 437.5$ Metagabbro and minor white granite

The basic dike, veins, and faults (fig. 9) have nearly vertical dips. The mineralized areas on the surface probably correlate with the zones of less highly radioactive hydrothermal veinlets at depth. The radioactive quartzbarite vein along the tension faults on surface. splits into two veins just north of the drill hole. A two-foot channel sample from the prospect pit north of, and nearest to, the drill hole contained 4.2 percent equivalent $\mathrm{ThO}_{2}$ (GG-47, table 4). In the drill hole below this vein at a depth of about 100 feet, two narrow veins were found. The core samples ranged from a trace to 0.2 percent equivalent $\mathrm{ThO}_{2}$. The manner in which the veins become weaker at depth suggests that the metagabbro is not a good host rock and only contains ore near its contact with the granitic rocks.

The Interval between 418 and 432.2 feet in the drill hole is microcline granite which has radioactivity of more than twice background. The granite is not fractured but fractured but a clearly detectible fetid odor suggests that it might be slightly mineralized. 
Draill hole no, Hada, and Drill hole Ha-2 cuts shear zone no. 2 in the southeastern part of the Haputa Ranch area. It passes below a shaft on shear zone no. 2 and a shaft on a subsidiary fault, 35 feet to the east. The shafts in this area were surik in seareh of gold, silver, and lead; a few pockets of galena were found in the eastern fault structure. The radioactivity of three samples (table 4) taken along shear zone no. 2 contained as much as 0.2 percent equivalent $\mathrm{ThO}_{2}$,

The core from the drill hole contained the same general suite of rocks (fig。10), as exposed on surface (fig。 3), except that the pegmatite was more abundant. A generalized log is given below:

$$
\text { Log of drill hole no. Ha } 2
$$

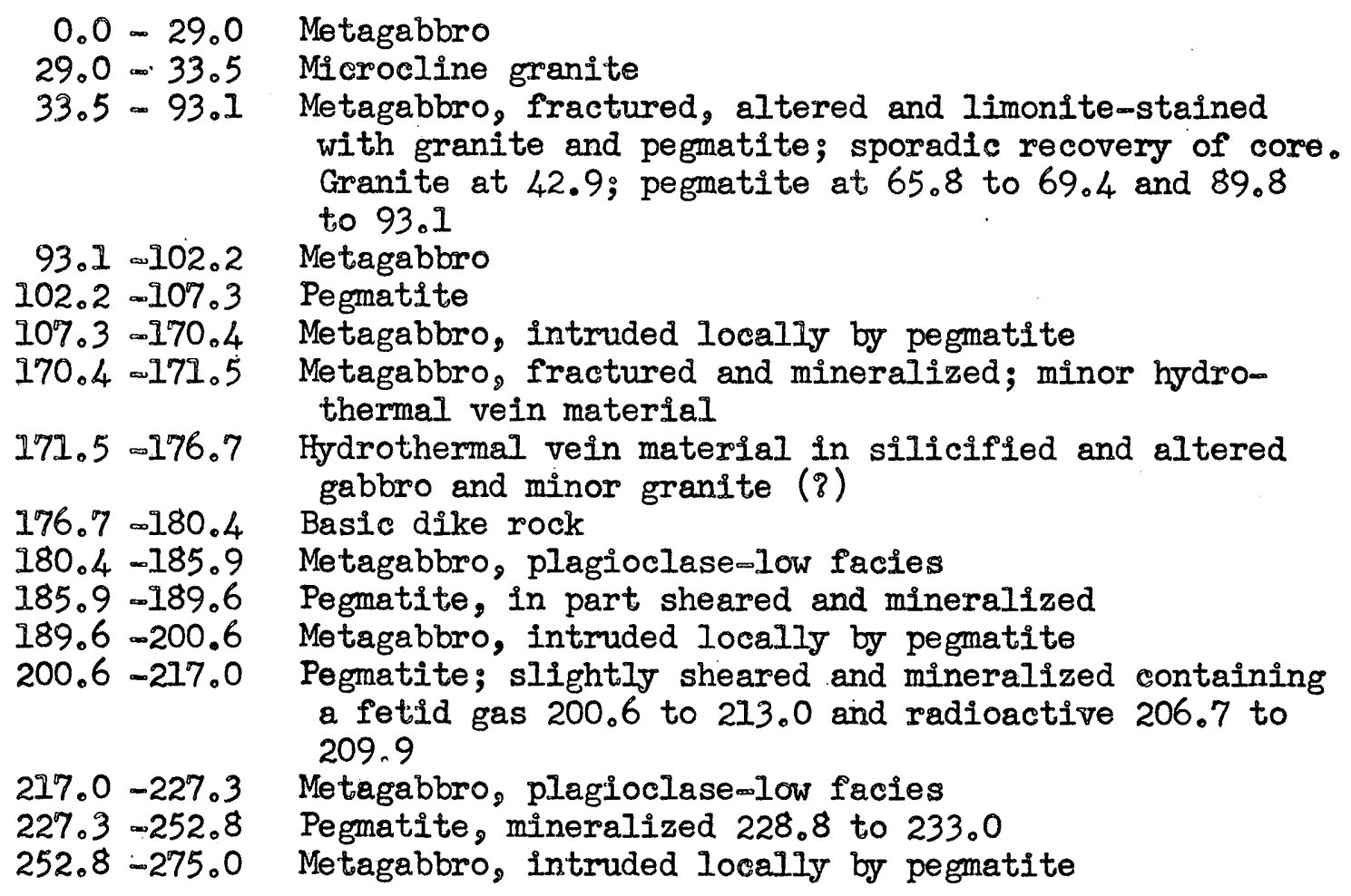

Radioactivity in the drill hole was strongest in the wall rock on the west side of the basic dike where minor hydrothermal veins cut the metagabbro. Analyses of five samples from drill hole no. 2 ranged from a trace to 0.3 percent equivalent $\mathrm{ThO}_{2}$. Very minor radioactivity was found east of the main 


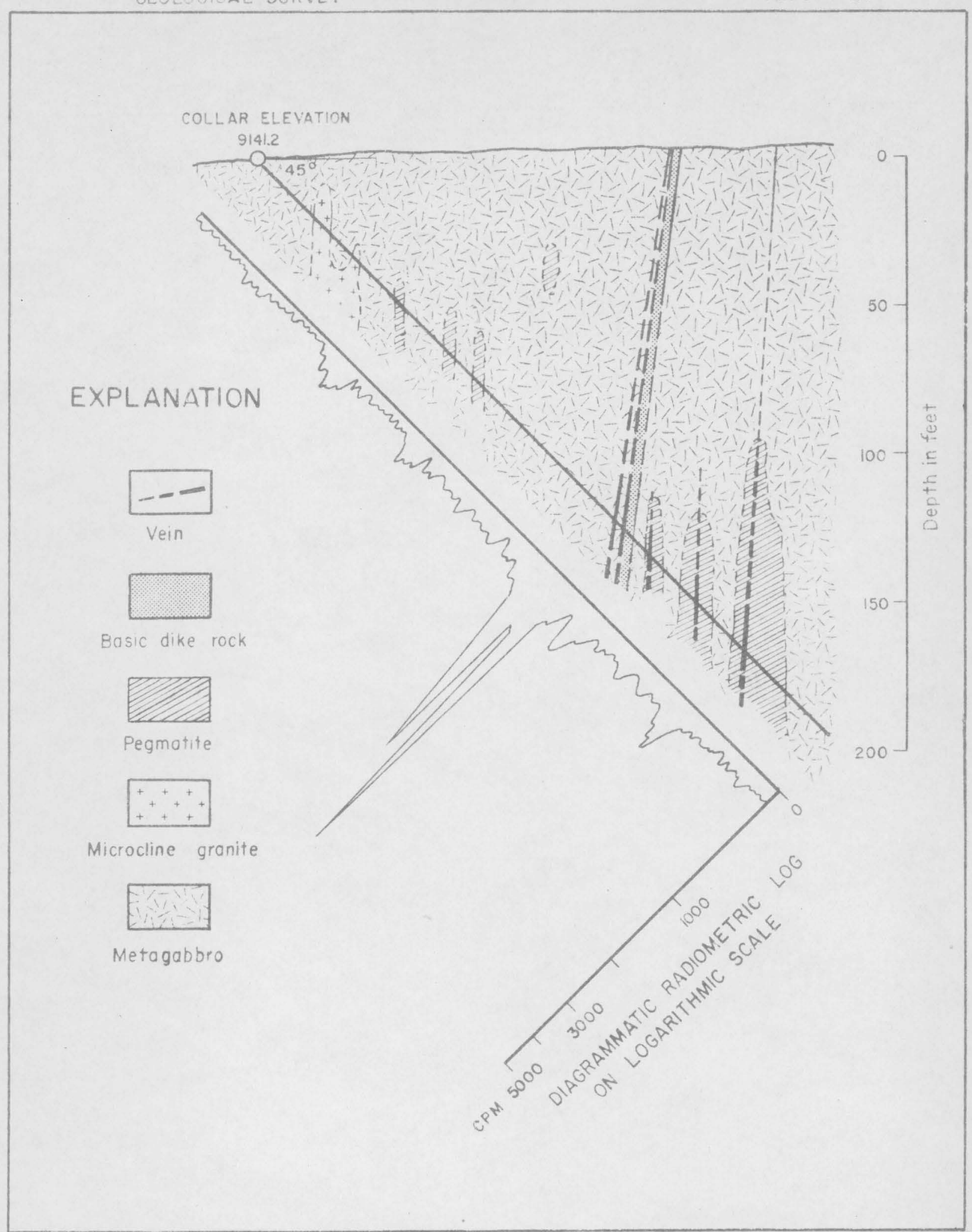

FIGURE 10,-SECTION THROUGH DRILL HOLE HA-2, CUSTER COUNTY, COLORADO 50 50 Feet 
shear zone where hydrothermal veins occur in slightly sheared pegmatites.

Drill hole no. Ha-1.-Drill hole Ha-1 near Ha-2, in the southern part of the area, passed beneath one of the most radioactive prospect pits on Haputa ranch; the-radioactivity in this pit, however, has no visible relation to a northwest-trending shear zone or to the other mineralized zones. The ore minerals occur in a fractured zone at the contact between a pegmatite and metagabbro. The contact appears to trend N. $70^{\circ} \mathrm{W}$. A careful study with the scintillometer failed to reveal any trend to the radioactivity.

A sample from this prospect (GG-76) contained 16.7 percent equivalent $\mathrm{ThO}_{2}$

The prospect pit and the drill hole are in metagabbro and minor pegmatite dikes (figs. 3, 11). Two weak zones of radioactivity were found In the drill hole; one small radioactive fracture zone and one pegmatite, containing a few crystals of brown radioactive mineral, were cut, At about 200 feet vertically below the pit, a non-radioactive fracture zone was encountered which might be the zone of strong radioactivity on the surface. A generalized log of the hole is given below:

Log of drill hole no. Ha-l
$0.0-41.9 \quad$ Metagabbro
41.9-42.4 Pegmatite
$42.4=74.5$
$74.5-75.3$
$75.3-161.6$
Metagabbro, minor pegmatite and white granite
Hydrothermal vein material along fractures
Metagabbro, in part the plagioclase-low facies, and
$161.6-162.2$ minor pegmatite and white granite
$162.2 .16 \% .1$
Pegmatite, slight radioactivity die to brown mineral
$167.1-169.2$ Metagabbro
$169.2-258.2$
Pegmatite
Metagabbro, much is plagioclase-low facies, and minor pegmatite
258.2 -259.2 Fractured zone in metagabbro
$259.2-292.8$ Metagabbro and minor pegmatite
292.8 -304.3 Fractured zone in metagabbro
$304.3-327.0$ Metagabbro and minor pegmatite 


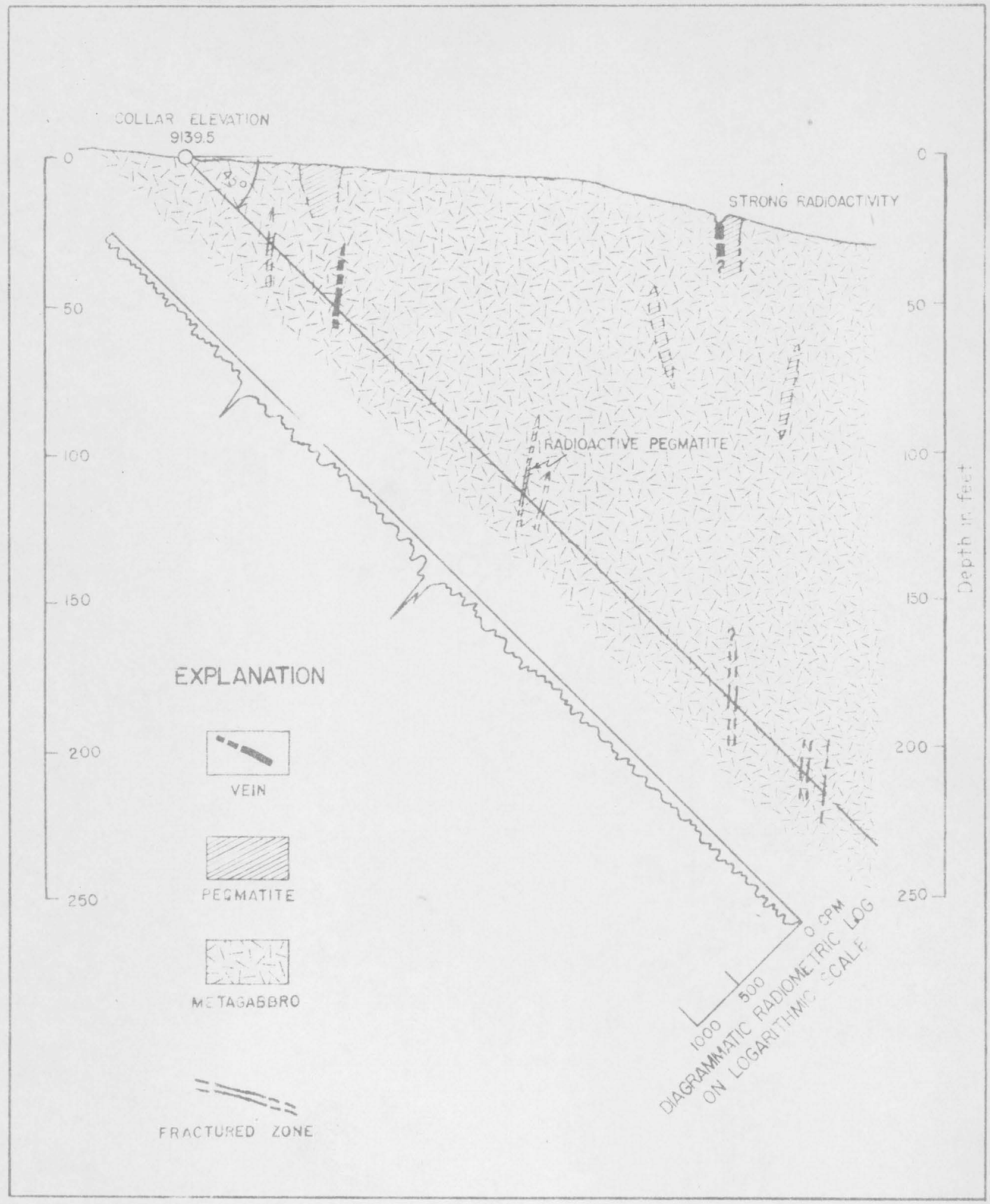

FIGUFE

SECTION THROUGH DRILL HOLE HA 50 0 50 Feet 
Drill hole no. Ha-4.--The purpose of drill hole Ha-4 (fig. 12), was to prospect shear zones nos. 3 and 4 at depth. Shear zone no. 3 is radioactive on the surface; the highest sample contains 0.4 percent equivalent $\mathrm{ThO}_{2}$ (GGu55, table 4).- Shear zone no. 4 contains negligible radioactivity. Drill hole Ha- 4 eut beneath an area which, at the surface, consists of metagabbro, in part the hornblendemich, plagioclase-low variety, and minor pegmatite. The drill hole passed through metagabbro, pegmatite, and microcline granite. The granitio material was more abundant in the drill core than on the surface. Basic dike rocks and very slightly mineralized fractures were cut at depth. A summary of the log is given below:

Log of drill hole no. Ha-4

$0.0-25.9$ Metagabbro with plagioclase-low facies. Last six feet weathered.

$25.9-28.6$ Microcline granite

28.6 - 54.6 Metagabbro, plagioclase-low facies, fractured and altered at 28.6 to 34.3 and 50.6 to 54.6

$54.6-60.0$ Mierocline granite

$60.0-92.3$ Metagabbro intruded by minor pegmatite and white granite

92.3 - 93.1 Microcline granite and metagabbro

93.1 - 161.6 Metagabbro cut by white granite stringers

$161.6-16404$ Metagabbro, pegmatite stringers and basic dike

$164.4=165.6$ Basic dike

165.6 -170.I Basic dike cut by hydrothermal vein material

170.I - 174.8 Metagabbro, plagioclase-low facies

$174.8-176.8$ Pegmatite

176.8 -237.3 Metagabbro with plagioclase-low facles

$237.3-243.8$ Microcline granite

$243.8-249.0$ Metagabbro

$249.0-251.5$ Basic dike with hydrothermal vein material

$251.5-274.0$ Metagabbro with plagioclase-low facies

$274.0-277.7$ Pegmatite

$277.7-294.3$ Metagabbro, plagioclase-low facies

The radiometric log of the hole indicated only a trace of $\mathrm{ethO}_{2}$. The equivalent $\mathrm{ThO}_{2}$ of five core samples was a trace (table 5).

Data from the drill hole shows that shear no. 4 dips $71^{\circ} \mathrm{NE}$ and shear zone no. 3 dips $88^{\circ} \mathrm{NE}$, suggesting that shear zone no. 4 joins shear zone no. 3 at depth (fig. 12). 


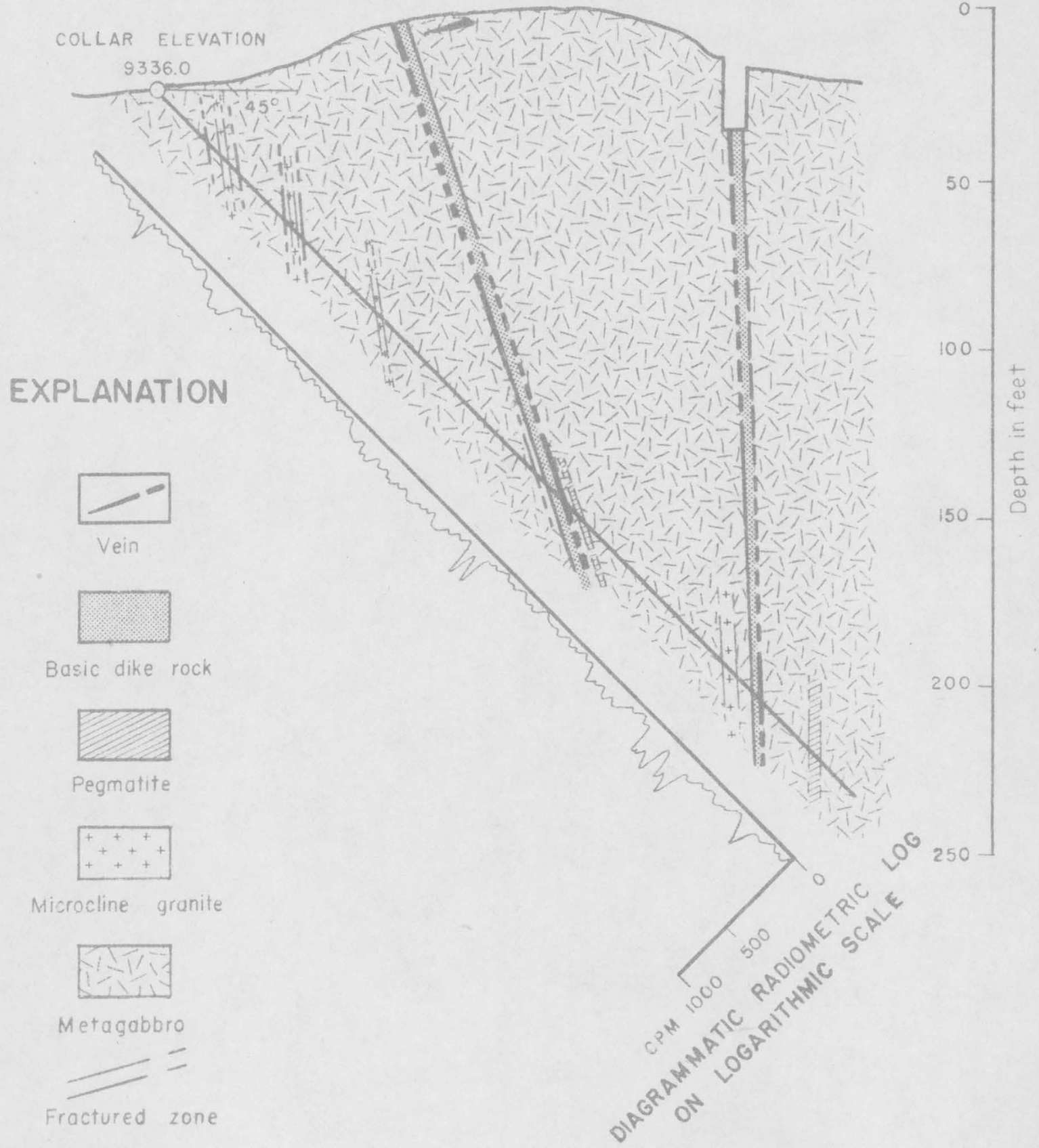

FIGURE 12. SECTION THROUGH DRILL HOLE HA-4, CUSTER COUNTY, COLORADO 
Drill hole no. Ha-5.-Drill hole Ha-5 which is about 240 feet SE of Ha-4 cuts shear zones no. 3 and no. 4. The surface prospect pits contained radioactive rock (table 4); two samples along shear no. 3 contained 0.1 percent equivalent $\mathrm{ThO}_{2}$.

The drill cut beneath granitic rocks at the surface area but encountered considerable metagabbro in its lower parts (fig. 13). Both shear zone no. 3 and no. 4 were radioactive where cored. A summary of the $\log$ is given below: Log of drill hole no. Ha-5

0.0 42.0 Probably largely biotite granite gneiss

42.0- 49.3 Pegmatite

49.3- 57.5 Metagabbro, fractured, altered and limonite stained

57.5- 63.0 Biotite granite gneiss

63.0- 71.8 Microcline granite

71.8- 95.8 Biotite granite gneiss

95.8-98.5 Metagabbro, fine-grained chill facies at contact with gneiss

98.5-147.4 Metagabbro, fractured and altered at 98.5 to 103.2 and at 127.8 to 137.7

147.4-148.6 Hydrothermal vein material

148.6-150.1 Basic dike

150.1-170.9 Metagabbro cut.10cally by white granite

170.9-182.2 Migmatite (biotite granite gneiss intruded by abundant

182.2-186.8 stringers of microcline granite along foliation plaines)

$186.8-188.7$

188.7-192.8 Basic dike

192.8 193.4 Hydrothermal vein material

193.4-210.6 Migmatite with minor pegmatite and conformable meta-

$210.6-211.6 \quad$ Pegmatite

$211.6-213.5 \quad$ Metagabbro

Shear zone no. 4 is dipping $83^{\circ} \mathrm{NE}$ and shear zone no. 3 is almost vertical; and apparently intersect at depth. The trend of the shears suggest that they intersect on the surface about 160 feet to the southeast.

The highest equivalent $\mathrm{ThO}_{2}$, calculated from the eU values of four core samples is 0.2 percent; the highest equivalent $\mathrm{ThO}_{2}$ obtained by the gammaray logging instrument is .0I percent for shear zone no. 3. These results, as well as those obtained in hole $\mathrm{Ha}-4$, seem to indicate that this part of 


\section{EXPLANATION}
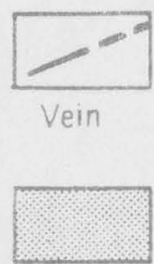

COLLAR ELEYATION

Basic dike rock

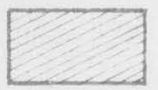

Pegmatite

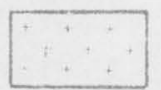

Microcline granite

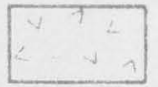

Migmatite

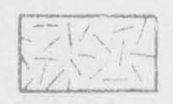

Metagabbro

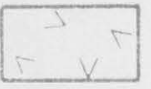

Biotite granite gneiss
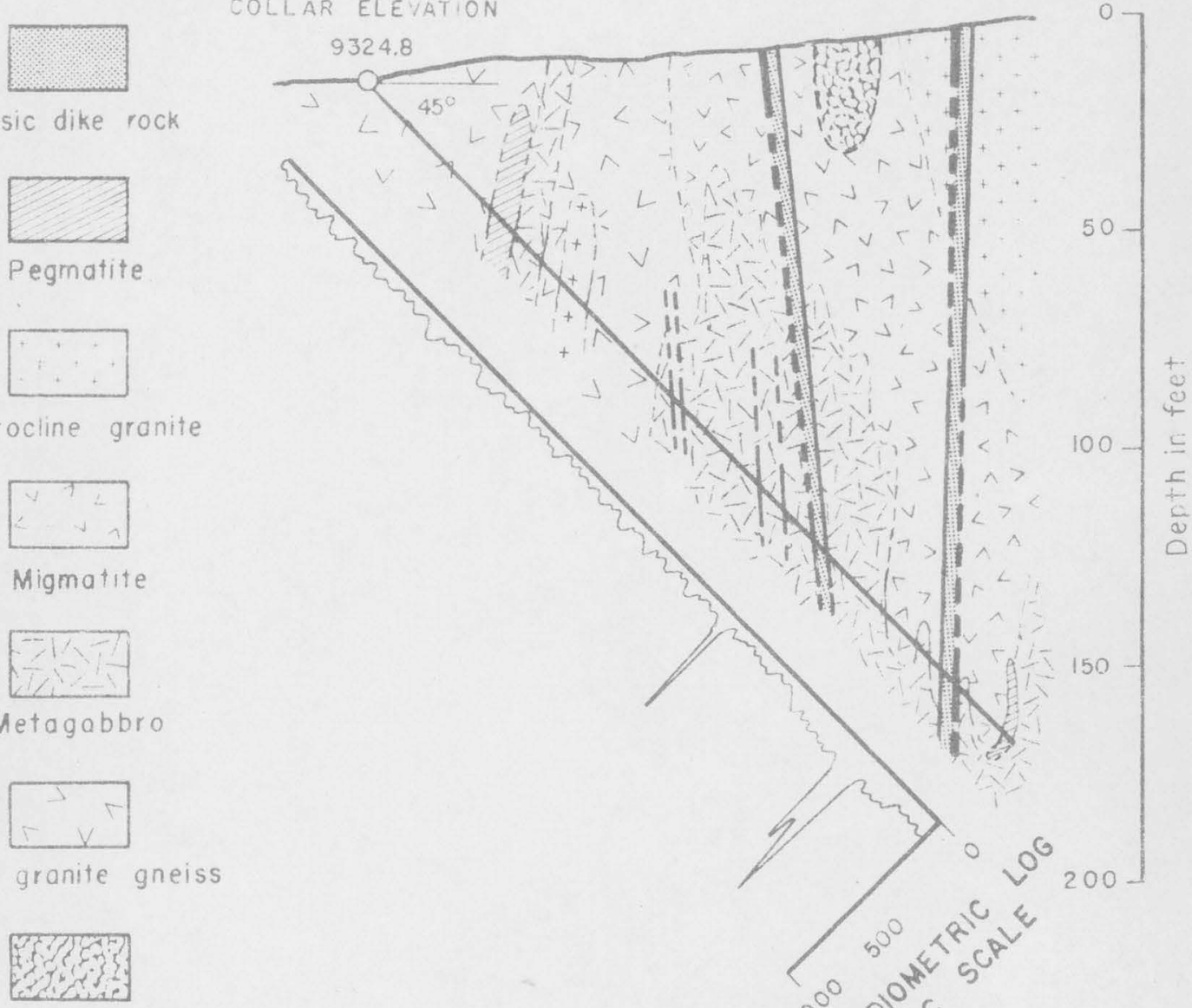

Amphibolite
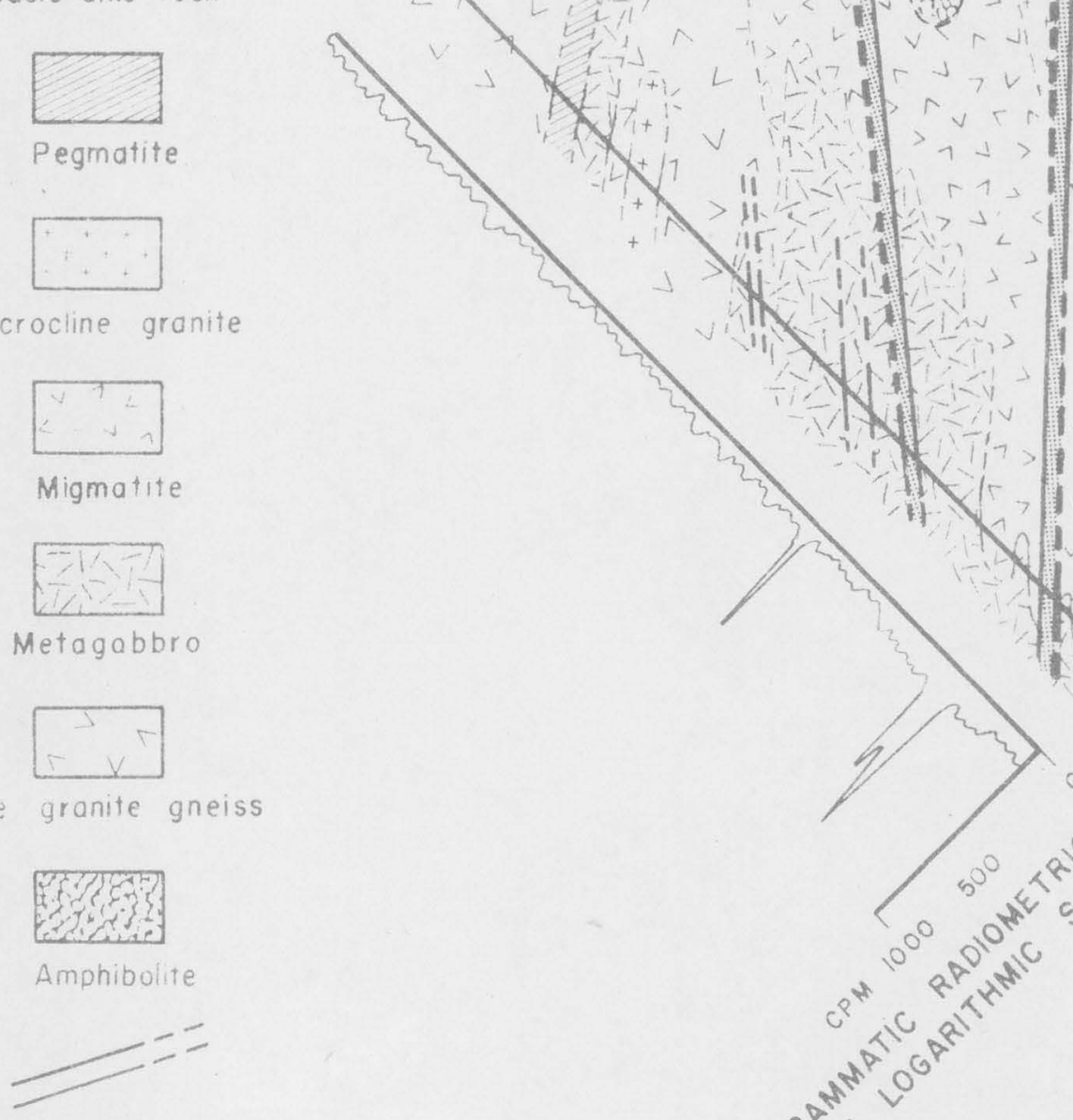

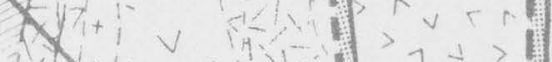

$-12+1+11-1-1+1+1$

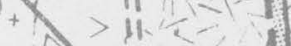

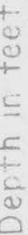

Fractured zone

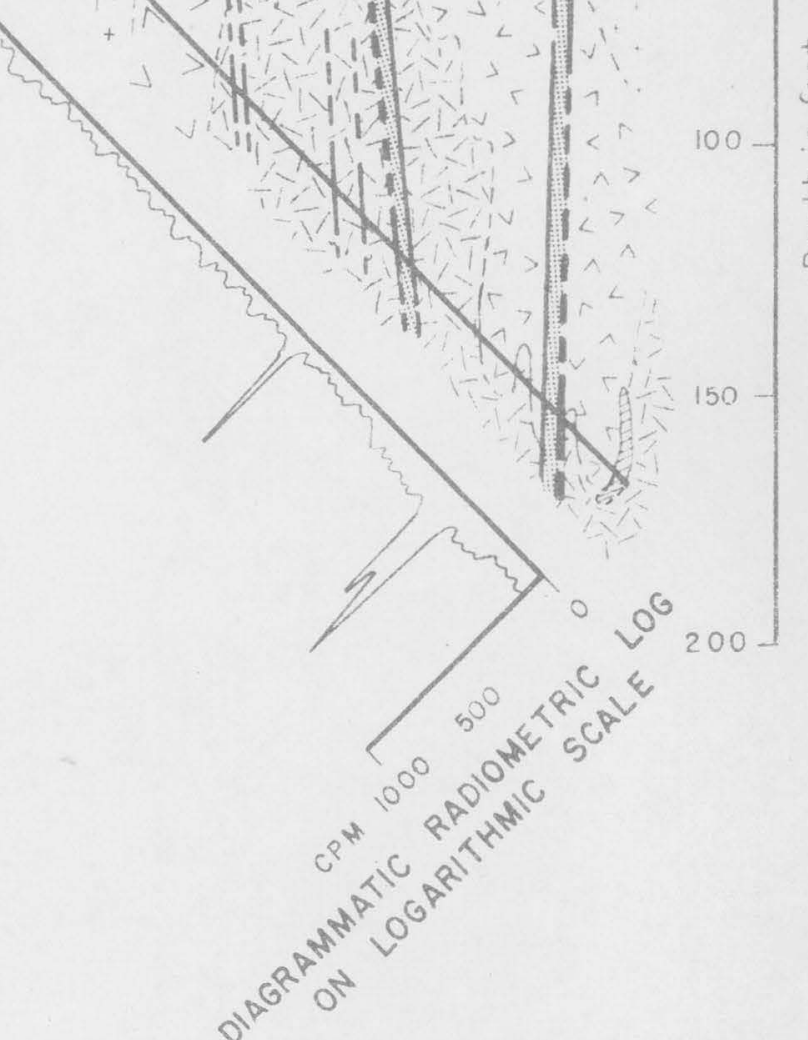

FIGURE 13- SECTION THROUGH DRILL HOLE HA-5, CUSTER COUNTY, COLORADO 
the structure is not particularly favorable for high grade thorium ore; however, because of the irregular distribution of ore along the shear zones, no strugture can be completely disregarded on the basis of so few drill holes. Drill hole Ha-2, - The objective of drill hole Ha-9 was to test for radioactive deposits at depth in shear zone no. 5 in the northern part of the mapped area. The droill hole was planned to cut near the intersection of two faults where much shearing has taken place. The veins have been prospected by two shafts and several prospect pits, they contain abundant quartz, iron carbonate, minor sulfides, and weakly radioactive material. The surface exposures consist principaly of biotite granite gneiss, migmatite, and amphibolite; a basic dike is exposed in one of the shafts.

Most of the core from the first 100 feet of the drill hole was highly broken and stained by limonite (fig. 14); locally it contains the fetid odor found in radioactive zones in this area. The syenite (?) dike and younger granite are easily correlated with the surface; the rest of the rock is a comples mixture of granitic rocks and amphibolite. The lower part of the hole is much less altered and consists of biotite granite gneiss. A generalized log is given below:

Log of drill hole no. HA-9

$0.0-34.0$ Highly broken and limonite-stained biotite granite gneiss, migmatite, amphibolite and minor younger granite 34.0- 41.3 Alaskitic microcline granite, broken and limonitestained, slightly mineralized with fetid gas

41.3-64.0 Migmatite and amphibolite with minor granite; pegmatite at 47.5 to 49.0 and 62.0 to 64.0

64.0-69.5 Syenite (?), slightly mineralized with fetid ador in last two feet

69.5-77.6 Highly broken and limonite stained, slightly mineralized granite, syenite (?), and amphibolite

$77.6-95.8 \quad$ Migmatite

95.8-103.3 Silicified, hydrothermal vein material

103.3-166.6 Biotite granite gneiss, in part migmatite, with amphi-

$166.6-169.8$ bolite and numerous small coarse-grained granite dikes $169.8-215.8$

Basic dike rock

Blótite granite gneiss, partly migmatized, and amphibolite 


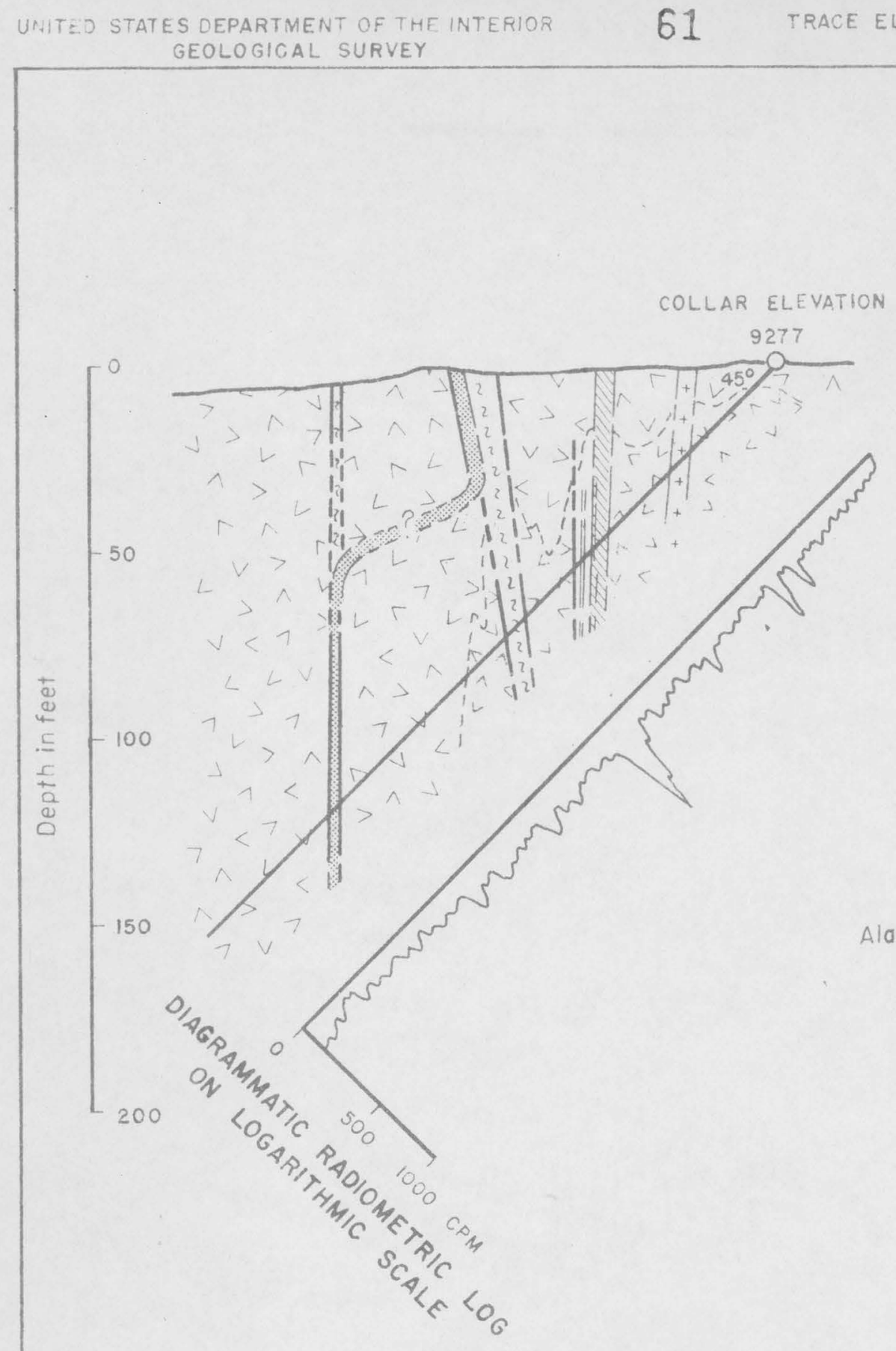

EXPLANATION REPORT 250

ISTIOATIONS
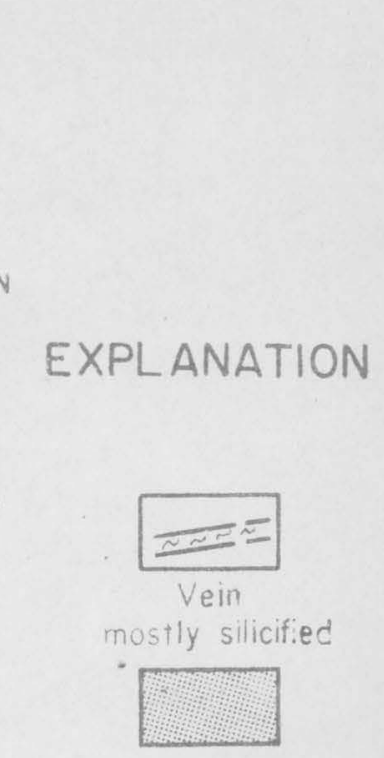

Basic dike rock

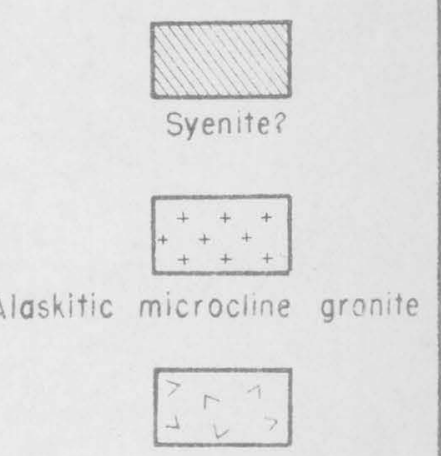

Migmatite

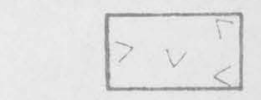

Biotite granite gneiss and amphibolite

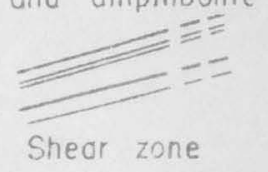

FIGURE 14 - SECTION THROUGH DRILL HOLE HA-9, CUSTER COUNTY, COLORADO.

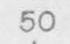

0 
The mineralized faults exposed at the surface are both found in the drill hole; the prinelpal difference is that the basic dike appears to have crossed over from one fault to the other between the surface and the 120 foot level (fig. 14)。The structures are nearly vertical except that the stronger shear appears to be dipping slightly northeast. Only the easternmost fault is radioactive at depth.

The surgace analyses (table 4 ) and the drill hole indicate that this deposit probably does not contain ore of economic interesto

\section{Haputa Extension}

The thoriumwbearing structures in the Haputa Ranch area extend northwestward into the area designated as the Haputa Extension. In JuIy 195.I, Dellwig and Heyman mapped about 0.2 of a square mile in this area at a scale of $1: 1,200$. This map (fig. 15) was partly revised subsequent to the exploration program, and the southeast onewfourth of the area was included in the revised map of the Haputa ranch area (fig。3)。

The geology in the Haputa Extension map area is similar to that in the Haputa ranch area to the southeast. No new rock units are present, although the abundance of each rock type is different. The major shear zones can be correlated across the alluvium valley fill between the two areas. Thorium minerals are less abundant in the shear zones exposed on the Haputa Extension.

Geology and thorium deposits

The gneissic microcline granites at Haputa Extension were not separated Into the three varieties as in the Haputa Ranch area. In the Haputa Extension the microcline granite charactized by biotite and a moderate to low quartz and 
microcline content appears to be the most abundant. It makes up many of the sills and dikes, including one dike that is at least 1,200 feet long.

Shear zone no. I is moderately radioactive in the northwestern part of the Haputa Extension, 2,400 feet northwest of drill holes Ha-3 and Ha-7. The vein in the shear zones is from 2 to 4 feet thick and consistently gives readings low on the 2.0 scale of a Geiger counter for a distance of 350 feet. The 2,400-foot length of the shear zone between the radioactive areas is largely covered by alluvium and colluvium; hence, it is possible that other pods of radioactive material occur but have not been detected. The samples collected from this shear zone contains from a trace to 0.9 percent equivalent $\mathrm{ThO}_{2}$ (table 6), less than 0.005 percent uranium, and as much as 0.15 percent rare earth oxides. Appreciable amounts of barite and galena occur with the radioactive material; galena is reported to have been mined from the shaft located in the northwest corner of the map.

The eastern of the two shear zones designated as no. 3 contains a biotite-bearing lamprophyre and a two-foot quartz-barite vein. In a pit at the northern end of the shear zone both the vein and dike are highly sheared; the dike is altered in part to a silver-blue, fibrous amphibole (?) mineral. The western shear is marked by reddish-stained granite, limonite, and weak radioactivity. Radioactivity can be traced less than 25 feet from the three pitæ on the shear zone, and the three samples contained a trace equivalent $\mathrm{ThO}_{2}$ ० A possible rare earth content of between 4.3 and 1.9 percent (LDmI and $I D=2$ ) in the unnumbered shear to the east is noteworthy.

A sample $\left(I D-U_{4}\right)$ taken at shear zone no. 4 to determine the value of maximum radioactivity contained 0.1 percent equivalent $\mathrm{ThO}_{2}$ - Radioactivity can be traced for about 50 feet, but is weak for all but about 15 feet. 
Table 6.-Analyses of surface samples, Haputa Extension

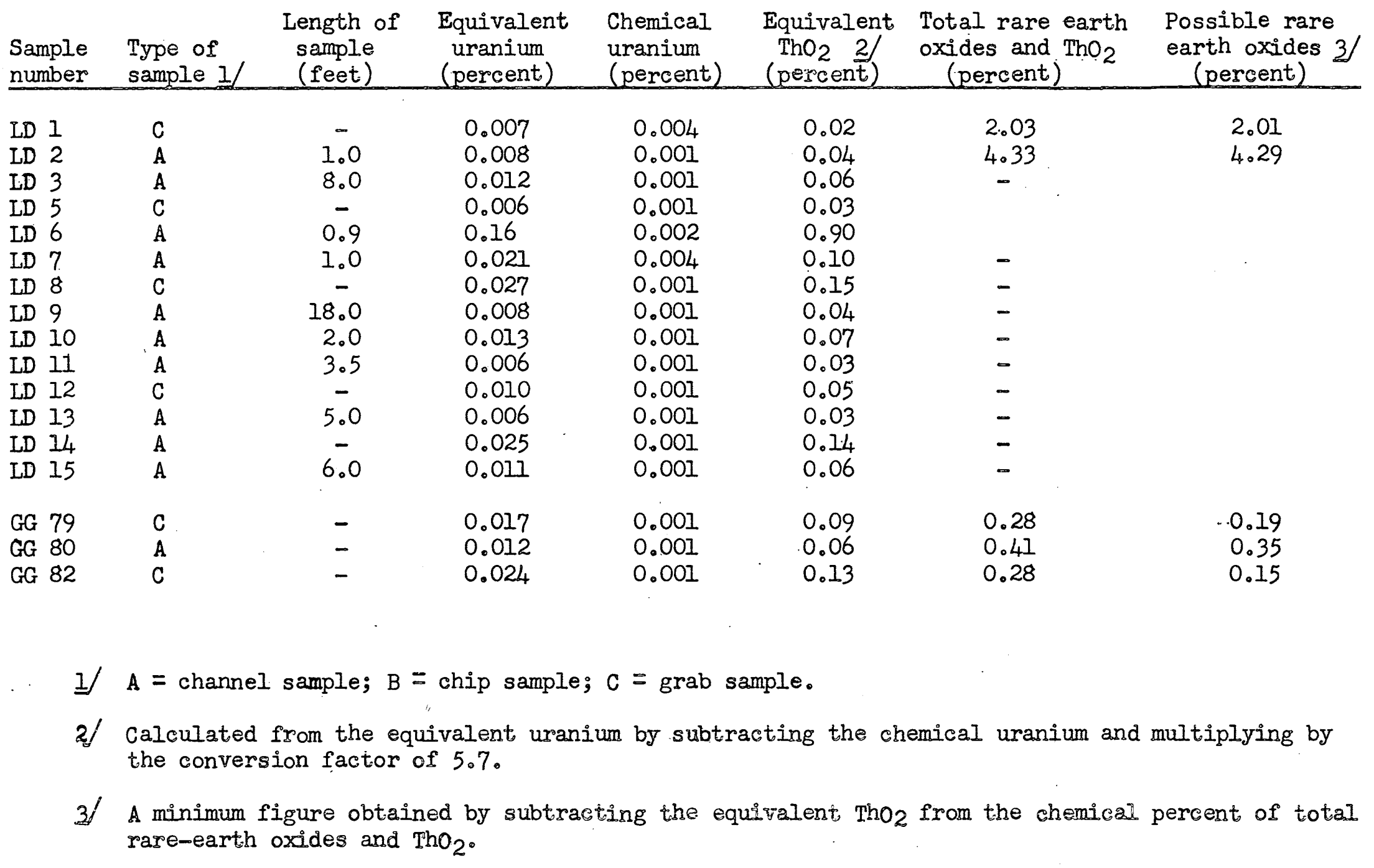


Black quartz crystals coat the granite wall rock in the single outcrop of the vein。

Shear zones no. 2 and no. 5 are weakly radioactive at the exposures in prospect pits and show no measurable radioactivity in covered areas between pits. Both contain quartzmbarite-siderite-limonite veins, 2. feet wide in shear zone no. 2, and 3 and 9 feet wide in shear zone 5, associated with silicified lamprophyre dikes. Terminated clear quartz crystals occur in white barite in the pit on shear zone no. 5. The average thorium content of both veins is low, but sample (LD-80) shows a possible 0.35 percent of rare earth oxide in shear zone no. 5.

\section{Greenwood property}

The Greenwood property, 3 miles north of the Haputa Ranch map area, is named, by the writers, after the owner of the surface rights, M. Greenwood. It includes three mining claims registered in the Custer County County Court House: (I) the Blue Bird claim, located by J. Susman and W. L. Susman; (2) the Cora B claim, owned by Henry G. Prior et al; and (3) the Pine Tree claim located by William Klein and Fred Jones.

The thorium deposits on this property were mapped in August 1951 by Dellwig and Heyman at a scale of 1:1,200 (fig. 16). Because of cover and limited time available only an outerop map of the area was prepared. The Pine Tree claim is reported to have yielded 400 pounds of hand-sorted thorite. 
Geology

The dominant rooks on the Greenwood property are probably biotite granite gnelss and horablende granite. Weathering has obscured their relationships, but they are considered to be about the same age and both contain inclusions of hornblende-plagioclase gneiss. These rocks have been intruded by diorite, gabbro, and peridotite and in the vieinity of the Pine Tree shaft, these rocks are accompanled by a dark green aphanitic rock, a fine-grained hornblendeplagioalase rock, and a cream colored plagioclase rock. Because they appear altered and leached these rocks have been designated as whighly altered and leaghed hornblende-plagioclase rock". All of the older rocks have been cut by numerous sillls and dikes of gneissic microcline granite, that in places form Injection gneiss, aplite, and pegmatite. Lamprophyre dikes of Tertiary age occur in the Pine Tree shear zone; in the two Bluebird shear zones; and In one of the three exposures of the Cora B shear zone. These dikes are pre $\propto$ mineralization in age.

The follation in the area has a prevailing trend averaging $N_{0} 600 \mathrm{E}$. with steep dips to the northwest. It is about parallel to most of the dikes and sills of granitic rocks.

The Cora B shear zones trend N. $60^{\circ} \mathrm{W}$. and dip $75^{\circ}$ to $85^{\circ} \mathrm{NE}$. The Bluebird and Pine Tree shear zones are roughly parallel to the Cora B shear qones In strike, but dip steeply southwest. On the Cora B claim, four independent shear zones or segments of mineralized fractures have been mapped. These are probably all part of the sam structure.

Two faults of small displacement have been mapped on the property. 
Thorium deposits

Extensive mining has been done on the barite-bearing vein of the Pine Tree elaim. Five shafts and two prospect pits have been dug along 600 feet of the exposed vein which averages four feet in width and is known to have contained small amounts of high grade thorite. This material, however, is not exposed at the surface and the workings at the bottom of the 60ufoot shaft aro Inacessible. The material on the dumps shows that the thorite occurs with barite, both with the white cleavage masses and the red granular varleries, and with minor quartz and galena. Blebs of pure thorite, as much as two Iriches in diameter, occur in the barite. The dump now contains very Iittie ore grade material because the ore was carefully hand-picked and the dump was subsequeatly" "picked over" for ore specimens.

Radioactivity could not be traced beyond the limits of the mapped vein. The thoritenrich part of the vein is thought to be about 300 feet long (based only on the inspection of the dumps). The vein exposed in pits outside this 300 10ot length is weakly radioactive. The grab samples from dumps of the Pine Tree workings contained from a trace percent to 0.1 percent equivalent $\mathrm{ThO}_{2}$ (samples LD 56,57 , and 58, table 7). The uranium content for these samples ranged from 0.001 to 0.002 percent.

The Cora B claim includes three shafts and four prospect pits along a N. $65^{\circ} \mathrm{W}$ ortrending shear zone. The vein is associated with a brown silicified dike and is two to four feet thick. It can be traced intermittantiy more than 550 feet. It is comprosed principally of vuggy, white, "ball" quartz crystals, many of which are coated with red hematite. No thorite was observed; the strongest radioactivity is associated with the hematite suggesting the presence of disseminated minerals. The radioactivity of the rock averaged about 2 on 
Table 7. -Analyses of surface samples, Greenwood property, Custer County, Colo.

$\begin{array}{llclll}\text { Sample } & \text { Type of } & \begin{array}{c}\text { Length of } \\ \text { sample }\end{array} & \begin{array}{l}\text { Equivalent } \\ \text { uranium }\end{array} & \begin{array}{l}\text { Chemical } \\ \text { uranium }\end{array} & \begin{array}{c}\text { Equivalent } \\ \text { Th02 2 }\end{array} \\ \text { number } & \text { Sample 1/ } & \text { (feet) } & \text { (percent) } & \text { (percent) } & \text { (percent) }\end{array}$.

$\begin{array}{lllllll}\text { LD } 56 & \text { A } & - & 0.007 & 0.001 & 0.03 \\ \text { ID } 57 & \text { C } & - & 0.008 & 0.002 & 0.03 \\ \text { ID } 58 & \text { C } & - & 0.025 & 0.001 & 0.14 \\ \text { ID } 59 & \text { C } & - & 0.058 & 0.001 & 0.32 \\ \text { LD 60 } & \text { C } & - & 0.033 & 0.002 & 0.18 \\ \text { LD 61 } & \text { C } & - & 0.010 & 0.001 & 0.05 \\ \text { ID } 63 & \text { A } & 1.0 & 0.026 & 0.001 & 0.14 \\ \text { ID } 64 & \text { C } & - & 0.024 & 0.001 & 0.13\end{array}$

If $C=$ grab sample; $A=$ channel sample.

2/. Calculated from the equivalent uranium by subtracting the chemical uranium and multiplying by the conversion factor of 5.7 . 
the 2.0 scale of a Geiger Mueller counter the readings being consistent over most of the length of the vein; samples contained a trace to 0.1 percent equivalent $\mathrm{ThO}_{2}$ (samples $\mathrm{LD}-61,63,64$ ). The fetid gas common to other radioactive deposits in the region is present in unusually strong concentrations In the quartz.

The shear zones on the Bluebird claim contain barite-limonite veins and sheared, silicified lamprophyre. They can be traced only about 150 feet. The only sample taken at the claim contains at trace percent e $\mathrm{ThO}_{2}$ (sample LD-56). The uranium content was 0.001 percent.

\section{Tuttle Ranch ares}

Thorium deposits were discovered on the Tuttle Ranch in 1950 by Gott and Dellwig. These deposits are nine miles north-northwest of the Haputa Ranch area (fig。2) and are owned by Willis Tuttle. The thorium-bearing area (fig. 17) was mapped by Dellwig and Heyman in August 1951.

\section{Geology}

The preclambrian rocks in the Tuttle Ranch area form a series of interlayered gneiss, injection gneiss, and granite cut by shear zones that trend northwest. The geology is similar to that of the Greenwood property except that the Tuttle area is less complex and does not contain diorite, gabbropyroxenite, or biotite granite gneiss.

Two varieties of gneiss, composed chiefly of hornblende and plagioclase, but distinguished by minor mineral constituents, outcrop in sufficient quantity to be mapped as individual units. These are quartz-hornblende-plagioclase gneiss and garnetiferous quartz-biotite gneiss which have been described above. 
Both varieties occur as small lenses interbedded with large masses of injection gneiss and gneissic microcline granite. The quartz-hornblende-plagioclase gneiss, however, also occurs as large masses or lenses in the southern and. eastern parts of the area. It is commonly jointed and epidotized, and the large bodies are slightly magnetic. The southernmost mass of gneiss is exposed in an area of 550 by 200 feet and is roughly concordant with the granitic gneisses; the smaller eastern body appears to be discordant. The single 70 foot quartzite lens is concordant with the foliation, and probably represents a silicarich metasediment of the gneiss series.

The most abundant rock type in the Tuttle Ranch area is the injection gneiss. Microcline granite seems to have been injected litmpar-lit into the gneisses, forming a continuous series which varies from almost pure gneiss to almost pure granite. Most noteworthy is the highly "granitized" variety that is a garnetiferous granite. A gneissic microcline granite similar to that which occurs as sills, and is responsible for the lit-par-lit injection, was mapped as discordant granite dikes.

Lamprophyres occur both in and out of the shear zones. The float of one resistant dike facilitates the tracing of the long shear zone on the eastern edge of the map through covered areas. No evidence of mineralization or subsequent shearing seems to accompany the two lamprophyres in the northw and southwestern parts of the area, though they are emplaced, in part, in joints or fractures with the same northwest trend as the shear zones.

Foliation in the area is singularly uniform, striking N. $45^{\circ} \mathrm{E}$. with an average dip of $55^{\circ} \mathrm{NW}$. In the southeast part to vertical in the northwest part of the area. Two prominent northwest-trending faults displace the layered sequence. The amount of displacement along the easternmost fault is not known; but along the westernmost one, the probable horizontal displacement is 
less than 15 feet.

Thorium Deposits

Seven mineralized shear zones were mapped in the Tuttle area; shear zone no. 5 is the most radioactive and can be traced, although discontinuously, for 2,700 feet. The vein averages about one foot wide, but in the southeastern prospect pits it is four feet wide. The radioactivity is spotty and weak over its entire length except for the southeasternmost 100 feet. Three samples (LD-52, LD -53, and LD-54, Table 8) from this area ranged from a trace to 2.4 percent equivalent $\mathrm{ThO}_{2}$. Other samples along the shear zone contained a trace of equivalent $\mathrm{ThO}_{2}$ (LD-39, LD-40, LD-4I, LD-42, and LD-49)。

Shear zone no. I is less than 500 feet long and one foot wide; the vein is exposed in several prospect pits, two trenches and one shaft. It is composed of pink barite, quartz, siderite, and a radioactive thorium mineral which is not megascopically visible. Three samples (LD-37, LD-38, and LD-48) ranged from a trace to 1.1 percent equivalent $\mathrm{ThO}_{2}$; the higher value is not representative of this shear and is a sample of selected vein material.

Shear zone no. 2 is about 30 feet long and 2.5 feet wide. Shear zone no. 3 is about 260 feet long and from several inches to two feet wide. Shear zone no. 4 is about 50 feet long and six inches wide. These are only weakly radioactive; the samples ( $L D-43, L D-44, L D-46, L D-47)$ ranged from a trace to 0.1 percent equivalent $\mathrm{ThO}_{2}$.

Shear zone no. 6 is about 200 feet long and two feet wide; it occurs im a brecciated granite. The sample (ID 65) from this zone contained 0.4 percent equivalent $\mathrm{ThO}_{2}$. Shear zone no. 7 contains malachite in quartz-hornblendeplagioclase gneiss with few other minerals; no radioactivity was found. 
Table 8. Analyses of surface samples, Tuttle ranch, Fremont County, Colorado

\begin{tabular}{|c|c|c|c|c|c|}
\hline $\begin{array}{l}\text { Sample } \\
\text { number }\end{array}$ & $\begin{array}{l}\text { Type of } \\
\text { sample } 1 /\end{array}$ & $\begin{array}{l}\text { Length of } \\
\text { sample } \\
\text { (feet) }\end{array}$ & $\begin{array}{l}\text { Equivalent } \\
\text { uranium } \\
\text { (percent) }\end{array}$ & $\begin{array}{l}\text { Chemical } \\
\text { uranium } \\
\text { (percent) }\end{array}$ & $\begin{array}{l}\text { Equivalent } \mathrm{ThO}_{2} 2 / \\
\text { (percent) }\end{array}$ \\
\hline ID 37 & c & - & 0.003 & 0.000 & 0.02 \\
\hline ID 38 & c & - & 0.20 & 0.002 & 1.13 \\
\hline LD 39 & A & 1.0 & 0.004 & 0.001 & 0.02 \\
\hline LD 40 & A & 1.5 & 0.000 & 0.001 & - \\
\hline ID 41 & $\ddot{c}$ & - & 0.003 & 0.000 & 0.02 \\
\hline ID 42 & c & - & 0.003 & 0.001 & 0.01 \\
\hline LD 43 & C & - & 0.009 & 0.001 & 0.05 \\
\hline LD 44 & A & 3.5 & 0.015 & 0.000 & 0.09 \\
\hline ID $44 \mathrm{~A}$ & C & - & 0.007 & 0.003 & 0.02 \\
\hline 45 & A & 0.9 & 0.016 & 0.001 & 0.09 \\
\hline ID 46 & A & 2.5 & 0.008 & 0.000 & 0.05 \\
\hline L 47 & C & - & 0.014 & 0.001 & 0.07 \\
\hline LD 48 & C & - & 0.008 & 0.001 & 0.04 \\
\hline L 49 & A & 1.0 & 0.008 & 0.001 & 0.04 \\
\hline L 50 & A & 5.0 & 0.14 & 0.002 & 0.79 \\
\hline LD 51 & C & - & 0.094 & 0.001 & 0.47 \\
\hline ID 52 & A & 4.0 & 0.11 & Q.002 & 0.61 \\
\hline ID 53 & A & 4.0 & 0.007 & 0.001 & 0.03 \\
\hline LD 54 & A & 0.4 & 0.36 & 0.002 & 2.04 \\
\hline L 65 & C & - & 0.063 & 0.001 & 0.35 \\
\hline
\end{tabular}

If $\mathrm{C}=$ grab sample; $\mathrm{A}=$ channel sample.

2/ Calculated from the equivalent uranium by subtracting the chemical uranium and multiplying by the conversion factor of 5.7 
Other minerals have a sporaic distribution in the area and along the shear zones. Quartz, either the vuggy or milky variety, and barite are the most common minerals. Much of the material in the shear zones has the fetid odor which is characteristic of the district. Large zoned quartz crystals coated with hematite are found at the northwestern part of shear zone no. 5.

... Other Thorium Deposits

\section{Anna Iee Lode}

Anna Lee Lode is $3-1 / 2$ miles north northeast of Querida and $3 / 4$ mile west of Colorado zroute 143 ( $f^{\circ}$ g. 2) and is claimed by Lee Jones and Lawrence Knobbe. The propertig was first visited by the Geological Survey eaxly in 1952. Several smal1 pits and trenches were examined and an isorad map (fig. 18) was made to determine the trend and approximate magnitude of the radio active depositi。 (Preliminary Reconnaissange Report Dm 470 was prepared on the basis of this work。)

The thorivm-bearing shear zones trend $\mathrm{N}_{0} 60^{\circ} \mathrm{W}$. through an area of granite whith is locally stained red. The total length of the shear has not been detexmined, but the discontinuous mineralized part, as indicated by the isorads of figare 18 , is about 1,000 feet long. The shear may continue to the noxthwest; heavy alluvium prevented further radiometric study of the vein in that direction. Narrow syenite dikes, shelared and heavily iron-stained, are exposed in the workings and probably trend parallel to the shear zone. The shear zone is entirely covered by a thin soil mantle except where exposed In the prospeet pits; consequently, no detailed study was made of the vein. The highest radioactivity fround with a GeigerwMeller counter was 13-20 on the 20 scale, in shear zones 2 to 10 inches wide. These are more strongly 


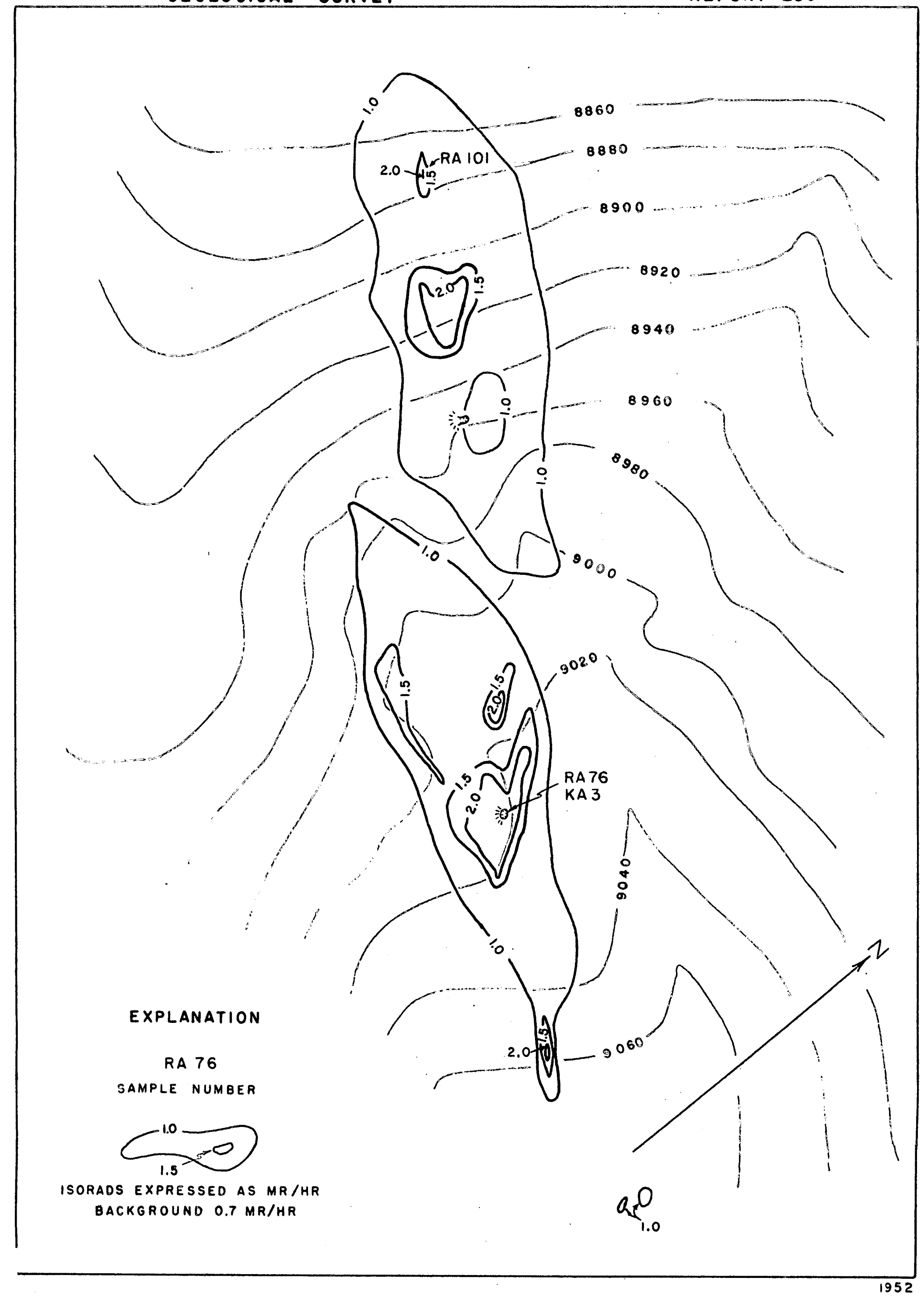

FIGURE 18.

ISORAD MAP OF ANNA LEE LODE, GUSTER CO., COLORADO 
Ixon-stained and sheared than the other rocks within the zone. The rein where best exposed in the easternmost plt (fig.18) strikes N. $47^{\circ}$ W., dips $85^{\circ} \mathrm{N}_{0} \mathrm{E}$. , and is about 10 inches wide. It consists of a sheared, finegrained, rod rock, probably altered syenite, that contains a 1-to 2-inch dark-128 stroingers of thorite (\%). The distribution of the "ore shoots" along the radioaetive shear zone probably it shown by the irregular distribution of Isorads (fig. 18).

A medirmougrained basic dike, very strongly altered to a soft, crumbly, Ilghtergray materelal, is adjacent to the radioactive shear in one of the shallow prospect trenches. Specular hematite occurs at one place is the shear zone as narrow stringers and lenses up to $1 / 4$ inch wide.

The locations of collected samples are shown on figure 18 and the results of the assays are in table 9. One grab sample (KR3) contained 6.8 pereent equipalent $\mathrm{ThO}_{2}$ and two channel samples (RA76-RAI01) ranged from 4.1 to 1.2 percent equivalent $\mathrm{ThO}_{2}$.

\section{Atomic Mountain Claim}

The Atomie Mountain claim is five miles north of Querida (fig.2) and Is owrsed by E. Sparling and I. Knobbe. A vertical vein is exposed in twro adits, ono shaft and numerous prospect pits and was traced for 1,200 feet along a shear zone that trends $\mathrm{N}_{0} 50^{\circ} \mathrm{W}$. The country rock consists of intexlayered granite and injection gneiss, strike $\mathrm{N}_{0} 40^{\circ} \mathrm{E}$, and dips $80^{\circ}$ NW. The vein varies from two to six inches in width and consists of quartiz, barite, limonite, and siderite.

The radioactivity is low to moderate; a maximm reading of 15 on the 2.0 scale was obtained with a Geiger-Mueller counter. The analyses 


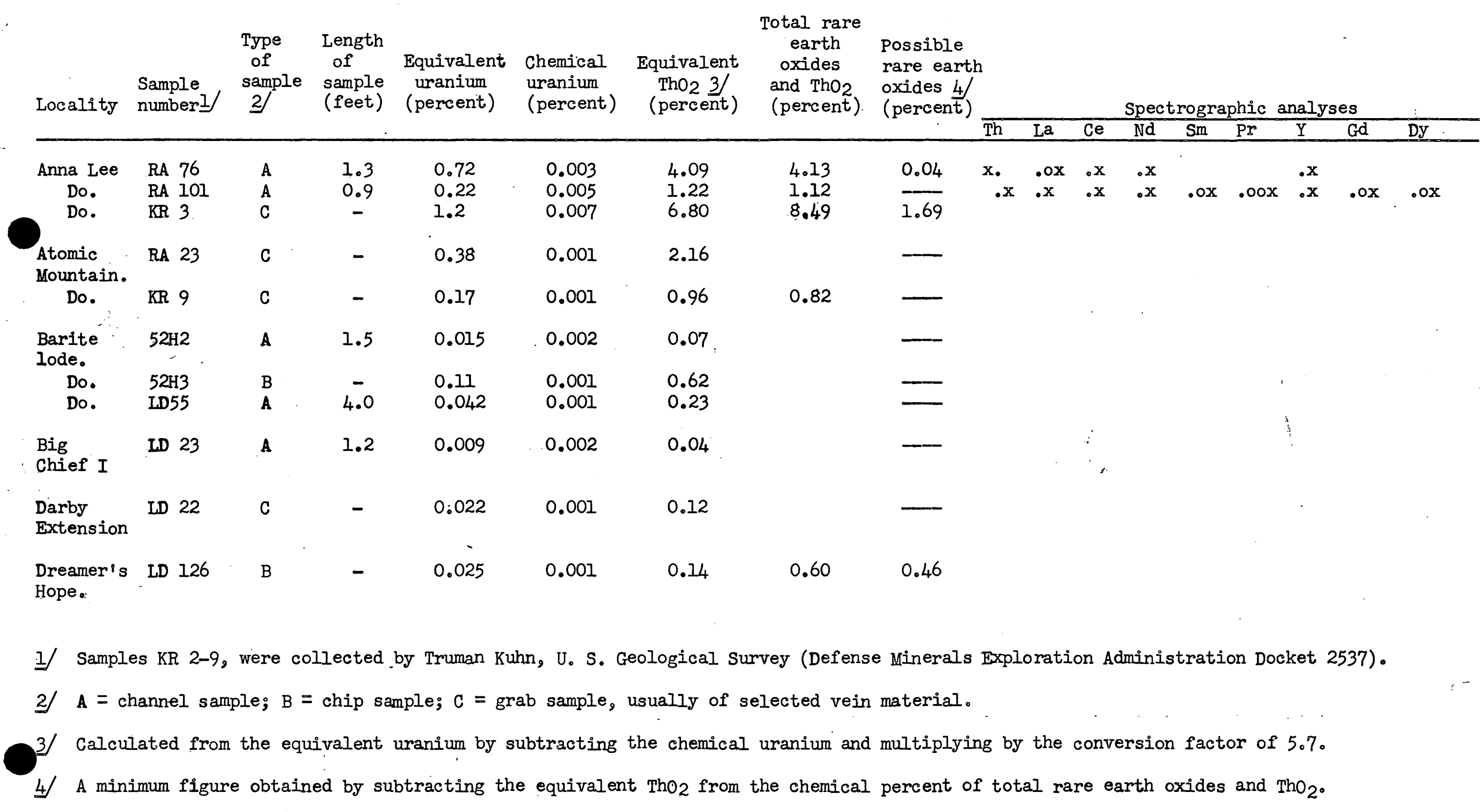




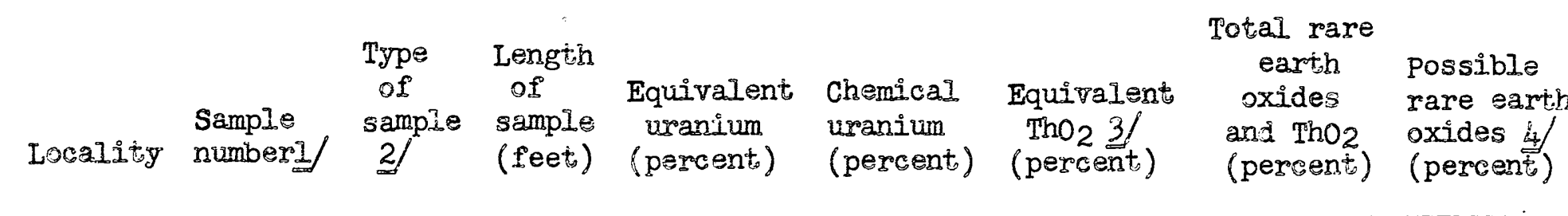

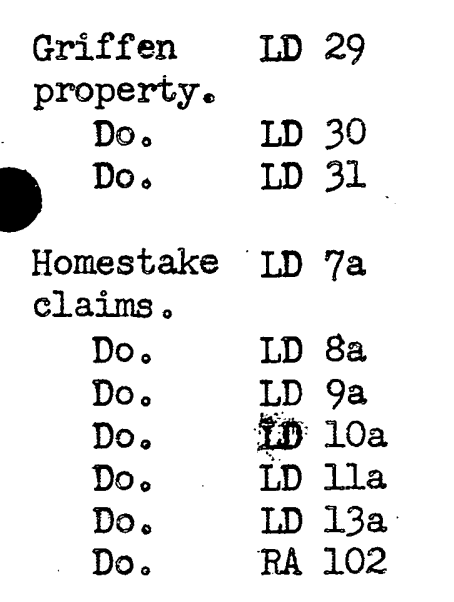

Lee Jones. ID 32

Lucky LD 26

Find.

Do。 LD 27

Do. ID 28

Do. KR 4

$\begin{array}{cc}- & 0.013 \\ 2.2 & 0.005 \\ - & 0.089 \\ - & 0.011 \\ - & 0.063 \\ - & 0.019 \\ - & 0.018 \\ - & 0.024 \\ - & 0.016 \\ 6.6 & 0.007\end{array}$

$\begin{array}{ll}0.001 & 0.07 \\ 0.001 & 0.02 \\ 0.058 & 0.18 \\ 0.001 & 0.06\end{array}$

0.07

A

$\mathrm{A}$

B

C

C

C
C
B

A

Mystery ID 24

lode.

$\begin{array}{ll}\text { Do. } & \text { LD } 25 \\ \text { Do. } & \text { KR } 5\end{array}$

Nighten- KR 2

- 0.022

0.001
0.001

0.06

0.63

0.57

0.35
0.10

$0.001 \quad 0.10$

0.003

0.001

0.10

0.12

0.08

$0.001 \quad 0.03$

\subsection{1}

0.82

0.27

4.52

0.26

0.07

6.46

0.72

0.17

4.40

0.08

0.04

$.0 x .0 x \quad .0 x \quad .0 x$

$.0 x$.00x

$.00 x$

pale.

$\begin{array}{ll}\text { Do. } & \text { ID } 33 \\ \text { Do. } & \text { ID } 34 \\ \text { Do. } & \text { ID } 35\end{array}$

A $\quad 20.0^{\circ} \quad 0.006$

0.001

0.12

$\begin{array}{lll}\text { A } & 7.0 & 0.004\end{array}$

0.001

0.03

$3.0 \quad 0.013$

0.001

0.001

0.02

- 0.14

0.002

0.07
0.79

0.73

$-\quad 0.006$

0.001

0.03

-097
$-\quad 0.10$

0.001

0.55

0.001
0.001

0.56

0.63

0.07

- $\quad 0.26$

0.004

1.46

1.85

0.39

$\begin{array}{lll}5.0 & 0.049 & 0.001\end{array}$

0.27

- 0.14

0.002

0.79

0.44 


\begin{tabular}{|c|c|c|c|c|c|c|c|c|c|c|c|c|c|c|c|c|c|}
\hline Locality & $\begin{array}{l}\text { Sample } \\
\text { numberl/ }\end{array}$ & $\begin{array}{l}\text { Type } \\
\text { of } \\
\text { sample } \\
2 /\end{array}$ & $\begin{array}{l}\text { Length } \\
\text { of } \\
\text { sample } \\
\text { (feet) }\end{array}$ & $\begin{array}{l}\text { Equivalent } \\
\text { uranium } \\
\text { (percent) }\end{array}$ & $\begin{array}{l}\text { Chemical } \\
\text { uranium } \\
\text { (percent) }\end{array}$ & $\begin{array}{l}\text { Equivalent } \\
\text { Th02 } 3 / \\
\text { (percent) }\end{array}$ & $\begin{array}{c}\text { Total rare } \\
\text { earth } \\
\text { oxides } \\
\text { and Th0 } 2 \\
\text { (percent) }\end{array}$ & $\begin{array}{l}\text { Possible } \\
\text { rare earth } \\
\text { oxides } 4 / \\
\text { (percent) }\end{array}$ & \multicolumn{9}{|c|}{ Spectrographic analyses } \\
\hline & & & & & & & & & Th & La & $\mathrm{Ce}$ & Nd & $\mathrm{sm}$ & Pr & $\mathrm{Y}$ & Gd & Dy \\
\hline $\begin{array}{l}\text { Pennie } \\
\text { Poker. }\end{array}$ & L $2 I$ & c & - & 0.064 & 0.001 & 0.36 & 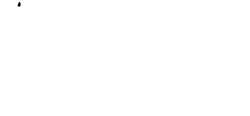 & & & & & & & & & & \\
\hline Sewell. & RA 71 & A & 4.0 & 0.013 & 0.0 .11 & 0.07 & 0.06 & & $.0 x$ & $.0 x$ &.$x$ & $.0 \mathrm{x}$ & & & $.0 x$ & & \\
\hline Do. & $\mathrm{RA} 72$ & A & 3.8 & 0.022 & 0.001 & 0.12 & 0.03 & & $.0 x$ & $.0 \mathrm{x}$ & . $x$ & $.0 x$ & & & $.0 x$ & & .- \\
\hline Do. & $\mathrm{RA} 73$ & A & 4.6 & 0.018 & 0.001 & 0.10 & 0.03 & & $.0 \mathrm{x}$ & $.0 x$ & . $\mathrm{x}$ & $.0 x$ & & & $.0 x$ & & \\
\hline Do. & $\mathrm{RA} 74$ & A & 3.5 & 0.012 & 0.001 & 0.06 & 0.03 & & $.0 x$ & $.0 \mathrm{x}$ & $.0 x$ & $.0 x$ & & & $.0 x$ & & \\
\hline Do。 & $\mathrm{RA} 75$ & A & 3.5 & 0.042 & 0.001 & 0.25 & 0.04 & &.$x$ &.$x$ &.$x$ &.$x$ & & & $.0 x$ & & \\
\hline Do. & RA 96 & A & 0.5 & 0.010 & 0.001 & 0.05 & & & & & & & & & & & \\
\hline Do. & RA 97 & A & 6.0 & 0.007 & 0.001 & 0.03 & & & , & & & & & & & & \\
\hline Do。 & RA 98 & A & 1.0 & 0.059 & 0.001 & 0.33 & & & & & & & & & & & \\
\hline Do。 & RA 99 & A & 0.9 & 0.11 & 0.002 & 0.62 & & & & & & & & & & & \\
\hline Do. & RA 100 & A & 1.0 & 0.014 & 0.001 & 0.07 & & & & & & & & & & & \\
\hline Spaulding & LD 36 & C & - & 0.008 & 0.002 & 0.03 & & & & & & & & & & & \\
\hline Starbuck. & RA 25 & A & 3.0 & 0.021 & 0.001 & 0.11 & & & & & & & & & & & \\
\hline Do. & $\mathrm{RA} 26$ & A & 1.0 & 0.18 & 0.002 & 1.01 & & & & & & & & & & & \\
\hline Do。 & RA 27 & $\ddot{A}$ & 0.5 & 0.060 & 0.001 & 0.34 & & & & & & & & & & & \\
\hline Do. & RA 28. & $\mathrm{c}$ & - & 0.30 & 0.001 & 1.70 & & & & & & & & & & & \\
\hline Do. & $\mathrm{KR} 8$ & C & - & 0.18 & 0.001 & 1.02 & 0.93 & & & & & & & & & & \\
\hline Stinkhole. & - $\mathrm{AH} 2$ & C & - & 0.30 & 0.001 & 1.70 & & & & & & & & & & & \\
\hline Do. & $\mathrm{AH} 3$ & A & 2.0 & 0.028 & 0.001 & 0.15 & & & & & & & & & & & \\
\hline $\begin{array}{l}\text { Sunrise } \\
\text { claims. }\end{array}$ & AH 4 & C & - & 0.24 & 0.027 & 1.21 & & & & & & & & & & & \\
\hline $\begin{array}{c}\text { Swartz. } \\
\text { Do. }\end{array}$ & $\begin{array}{ll}\mathrm{RA} & 51 \\
\mathrm{RA} & 52\end{array}$ & $\begin{array}{l}\mathrm{C} \\
\mathrm{C}\end{array}$ & & $\begin{array}{l}1.2 \\
0.40\end{array}$ & $\begin{array}{l}0.005 \\
0.005\end{array}$ & $\begin{array}{l}6.81 \\
2.25\end{array}$ & & & & & & & & & $:$ & & \\
\hline
\end{tabular}


of one sample (RA-23, table 9) of material believed to have came from the bottom of the shaft represents the highest grade ore specimens forwa on the dump; it contained 2.2 percent equivalent $\mathrm{ThO}_{2}$.

\section{Barite Lode}

The Baxite Lode, belonging to Pete Gowan and George Schwigert, is about six miles east of Westcliffe along route 96 and consists of a carred shaft, about eleven prospect pits, and two bull-dozed trenches along a distance of about 3,000 feet. The claim was visited by Dellwig 1. 1951 and revisited by Heyman in 1952.

The deposits occur along several northwest-trending mineralized zones in an area of microcline granite and quartzmomblende and granite gneisses. A highly silicified brown dike rock occurs in some of the shear zones. Four different shear zones appear to have en echelon arrangement; they waxy in strikse from $\mathrm{N}_{0} 67^{\circ} \mathrm{W}$. to $\mathrm{N}_{0} 45^{\circ} \mathrm{W}$ and dip $70^{\circ} \mathrm{NW}$. to vertical. The pin material has a maximum observed width of six feet, but generally is much narrower. It is composed of limonite, massive red, basite, white and smoky quartz, hematite, thorite (q), and minor galena. The thorium occurs with the massive rea hematito.

The two channel samples, totaling 5.5 feet, from the discovery shaft contained $\mathrm{O}_{0} \mathrm{I}$ and 0.2 percent equivalent $\mathrm{ThO}_{2}$ (samples $52 \mathrm{H} 2$

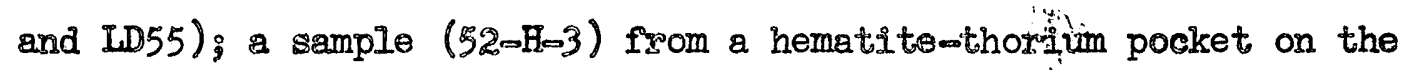
east wall of the shaft contained 0.6 percent equivalent $\mathrm{ThO}_{2}$ (table 9). The uranivm content of the samples was 0.001 to 0.002 percent.

\section{Big Chief I claim}

The Big Chief I claim, east of highway 143 about 1.5 miles north of IIse, is owned by A. P. Jensen. Oroginally staked as the wStas 


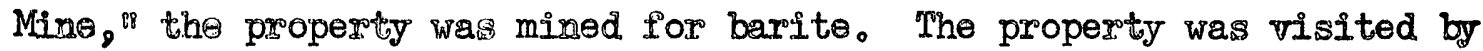

I. F. DeIlwig in July 1952 (Preliminary Reconnaissance Report No. D-369). There are wusrous workings throughout the length of the pein.

The wall rook is injection gneiss which strikes $\mathrm{N}_{0} 70^{\circ} \mathrm{E}$. and dips $85^{\circ} \mathrm{NW}$. The steeply dipping rein is exposed for 400 feet along a $\mathrm{N}_{0} 10^{\circ} \mathrm{W}$ trend. It pinches and swells from $2-1 / 2$ inches to 4 - I/2 feet. Barite, quartz, and iron carbonate are abundant; galena and chalcopyroite are present in small amounts. The radioactivity although low is fiairly constant along the rein. The maximum Celger-counter reading was 15 on the 0.2 sele.

A fifteen inch channel sample ( ID-23, table 9). gave a trace of equivaleat thoria ralue of 0.04 percent.

\section{Charleston properioty}

Tour prospeet pits oseru in moderately radioactire rock one and onehalf miles eastrusoutheast of Querida on the Charleston ranch. These are along a N. $20^{\circ}$ W. vertical shear zone. The shear zone is five to ten feet wide, 300 ieet long, and contains a dark red to black nondescript silieified roek which probably represents a completely altered basic dike. The maximum radioacimity recorded was 4 on the 20 scale, and much of the rein materrial was orex 10 on the 2.0 scale.

\section{Darby Extension property}

C. I. Bxiggs holds patented rights to the Darby Extension propertio on the A. Griffen ranch just eight miles north of Querida (fig。2)。I.F。Dellwig visited the property during the summer of 1951 (Preliminary Reconnaissance Report D-26E). The workings consist of two shafts with estimated depths of 
100 feet and 25 feet, and several prospect cuts and adits.

The mineral deposit is in a 100-foot wide, northwest-trending fault zone that has known lateral extent of orex 9,000 feet. The vein minerals axe quartz, celeite, barite, iron carbonate, pyrite, chalcopyrite, galena, and fine-grained, dense, red and earthy brown limonitio rook; both bypes of limunitic rook are radioactite. The country rock is hornblende gneiss and graniti。

Dellwig's grab sample (ID22) from the dump of the larger shaft contained 0.1 percent equivalent thorium oxide (table 9). A later examination of the shear zone revealed stronger radioactive rock a short distance to the east; the Geiger-Mueller counter readings recorded were as much as 3.5 on the 20.0 scale, including numerous 2.0 scale readings.

\section{Dreamer's Hope clain}

The Dreamer's Hope claim is in the vicinity of the Homestake claims, 3.9 miles east of state route 69 , about six miles northeast of Hillside, Fremont County (fig.2). Weak radioactivity is found along a shear zono trending N. $55^{\circ} \mathrm{E}$. in microcline granite. The maximum radioactivity found was 5 on the 2.0 scale (Geiger-Mueller counter, Model 2610A). Dellwig and Gott collected one sample from the Dreamer's Hope in 1950. It contained a possible 0.5 percent rare earth oxides and 0.14 percent equivalent ThO 2 (sample LD-126, table 9.) The prospect is reported to have been worked for lead.

\section{Griffen propertir}

Albert Griffen's property, 1.1 miles north of the junction of State Highway 143 and 277, was visited by Dellwig in July 1951 (Preliminary 
Recontiasssance Roport D-262). A northern voin with an attitude of N. $80^{\circ} \mathrm{W}_{0}, 75^{\circ}$ SW. Was traced for only 50 feet; another vein 70 feet to the south with an attltude of $N_{.} 80^{\circ}$ W. $75^{\circ}$ SW., contained radioactive materdal for a distan of 270 feet. The southern vein was traeed about, 2,000 feet farther southeast, but only slight radioactivity was fowd over this distance. Both voins cut finomgrained microoline granite groiss of pre-Cambrian age. The north vein, exo posed in 3 alowely spaced prospect pits, is about 3 reet wide and consisto pxircipally of pink barite with small amounts of siderite and quarti. The win material was fractured then recemented with a red material which is slightly radioactive. The south vein appears to follow a shear zone, two to three feet wide, with a silicified basic dike adjacent to the northern edge of the rein. Rod, massivo hematite along with some spegularite, barite, and chalcopyrite occurs in the pit in which the highest radioactivity was found.

The maximum radioaetivity is a reading of 20 on the 0.2 scale of a Victoreen Ceiger counter. Three samples ranged from a trace to 0.2 pefcent equifilent Th82 (samples ID 29, 30, and 31, table 9).

\section{Homestake Claims}

The Homestike olaims are 3.9 miles from highryy 69 about six miles northeast of Hillside, Fremont County (fig. 2). The claims occur along shear zones (8) trending $\mathrm{N}_{0} 55^{\circ} \mathrm{E}$. in an area of microcline granIte. The granite has foliation that strikes $\mathrm{N}_{0} 55^{\circ} \mathrm{W}$. to $\mathrm{N}_{0} 70^{\circ} \mathrm{W}$. and dips $60^{\circ} \mathrm{NE}$. to vertical. Weakly radioactive material is found at three prospect pits and one shaft on the Dreeamer's Hope and Homestake No. I structure ower a distanoe of about 2,000 feet; the masimum radio- 
activity was 5 on the 2.0 scale of a Geigex-Muller countez.

Dellwig and Gott visited the area in 1950 and collected six samples that contained as much as 6 percent rare eapth oxides and 0.3 percent chemical $\mathrm{ThO}_{2}$.

\section{Lee Jones propertity}

The thoxium property on Iee Jones ranoh, 5 milles northeast of Querida (fig. 2) was examined by Dellwig in July 195I (Preliminaxy Reconnaissanee Report D-368). Three prospect pits, located over a total distance of 100 feet, mark a N. $55^{\circ} \mathrm{W}$. trending shear zone. The country roek consists of fine-grained and dark coarse-grained varieties of microcline granite. Moderate radioactivity was associated with Iimonitic stained rock; no other evidence of mineralization was observed. The maximum radioactivity recorded was 5.5 on the 2.0 scale for two hand specimens from the north dump which were chosen as a grab sample to represent maximum radioactivity. Although this sample analysed 0.1 percent equivalent $\mathrm{ThO}_{2}$ (mample ID-39, table 9), radioactivity in most of the shear is only slightly above background.

\section{Lucky Find eloim}

The Iucky Find claim, owned by E. Sparling and Io Knobbe, is 4 miles north of Querida (fig. 2). In JuIy 195I, Dellwig examined the property (Preliminary Reconnaissance Report D-367). The workings consist of two prospect shafts, each 15 feet deep, and several smaller pits.

The Irack Find deposit is in a moderately radioactive vertical shear zone, 2 to 7 feet thick that has a known length of about 1,500 feet. It's average trend is $\mathrm{N}_{0} 70^{\circ} \mathrm{W}$. The country roek is injection gneiss that 
strikes $N_{0} 70^{(0)} \mathrm{E}_{0}$ and dips rertical. The voing in the shear zono, pinches and \$w IIs from one to two feet in thicknoss. The principal roin mineral is baroite that with quartz has been broken, sheared, and rem cemonted. Slickensides are common in the shear zone and are coated with thorite. A lxmprophyre dike of promineral age paxallels the south side of. the rein, and contains some chaleopyrito.

Throe Ghaniel samplos were taken, two from the westermmost shaft and 400 Peet east of the easternmost shaft. These contained from

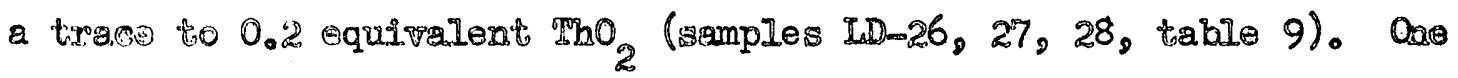
geab gample costained 0.8 equitalent $\mathrm{ThO}_{2}$ (sample wosternmost shaf' had a radioactivity of as meh as 10 on the 2.0 seale.

\section{Mrsten Iodi}

The Mrstexy Low is near the Creenwood property, about. 3 miles soutbwest of IIse. The ownexs of the claim are E. Sparing and I. Knobbe. The worikings consist of a 20-foot shat?. The property was examined by Da1lwrig in 2951 (Preliminary Reconnaissance Report D-265)。

The Myztery Lade is on a two-foot quartz nin of unknown length, that cuts injection groiss. The strike of the vein is $\mathrm{N}_{0} 15^{\circ} \mathrm{W}$, and the dip is $60^{\circ}$ SW., the Poliation of the injection gneiss is N. $\mathbb{N}_{0} 60^{\circ}$ and nearly rescincal.

Baxpto, gphalerolte, galena, and chalcopyrite are present in small quantities as stroingers and isolated blebs in a gangue of vuggy quarts. Both mily and smoky quartz is in zoned crystals in the vugs.

Thros samples fyom the dump were selected to determine maximm radioaelivity. These contained from a trace to 0.6 equivalent $\mathrm{ThO}_{2}$ (samples idould, 25, KR-5, table 9). 
Nightengrie olaim

The Nightengale claim, owned by Lawrence Knobbe and J. Tomsick, is 1.4 miles east of Querida (fig. 2). It was visited by Dellwig in July 1951 (Preliminary Reconnaissaneo Report D-366).

The claim consists of 3 prospect pits along a 6-foot vertical shear zone that trends $N_{0} 45^{\circ}$ W. Because exposures are poor the shear zone was traced for only 100 feet; both ends are exposed by prospect pits. The large pit on the northwest end has exposed an aplite dike which has been sheared and somewhat mineralized with quartz veinlets, galena, chalcopyrite, and pyrite; no barite is present. A maximum reading of 13 on the 2.0 scale of a counter indicates moderate radioactivity. Nearby, another mineralized zone, indicated only by black staining of the grenitic country rock and by radioactivity, is exposed in a prospect pit. In some places the stain completely penetrates the rock, in others only a thin coating is apparent; 175 feet to the south the stain is only slight. The strueture is probably a shear zone in granite with slight mineralization. Moderate to high radioactivity is shown by a maximum reading of 3.5 on the 20.0 scale of a counter.

Three samples contain from 0.3 to 0.8 percent equivalent $\mathrm{ThO}_{2}$ (samples ID-33,34, and 35, table 9). A selected sample contained $1_{8} 5$ percent equivalent $\mathrm{ThO}_{2}$ (sample $\mathrm{KR}-2$ ). 


\section{Pannie Poker elaim}

The Pennie Poker patented ( $\mathrm{g}$ ) claim is on the same mineralized fault as the Daxiby Extension and joins that claim on the north. The property was leased by Ernest Sparling in 1951. It was examined by Delwig in 1951 (Preliminary Reconnaissance Report D-264). Mine workings include a 25-foot shaft, an adit with workings estimated at over 100 feet, two prospect cuts, and a prospect shaft. The radioactive zone Is similar in composition, but much narrower, than the Darby Extension vein. The average width of the shear zone is about 15 feet; the vein averages 3 fiet.

A grab sample collected from the shaft dump assayed 0.064 percent equivalent uranium or 0.4 equivalent thorium oxide (sample LD-2I, table 9). Geiger Mueller counter readings up to 4 on 20.0 seale, including several 2.0 seale readings, were recorded.

\section{Sewell Ranch property}

Sewell Ranch property is in Hardscrabble Canjon (fig. 2). The radioactive rain is on a ranch owned by George $F_{0}$. and Clance A. Sewell, and is leased to Eugene Acheson and Lewis G. Mundy. The workings consist of two 40-foot adits, a 40-foot shaft, and several prospect pits. This deposit was examined and mapped in the spring and sumer of 1952 by Christman and Hyman (Preliminary Reconnaissance Report 469). An isorad map of the property is shown in figure 19.

The thorium is in a quartz-barite-limonite vin 6 to 10 feet thick and at least 1,000 feet long. It has an average strike N. $45^{\circ} \mathrm{W}$. and dips

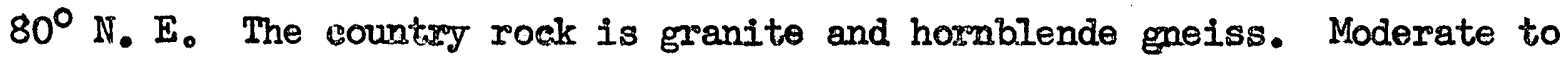
weak radioactivity oecurred throughout the length of the in; the strongest 
radioamivity was assogiated with barito. The in is strongly sheared and contain abrudant earthy, red iron oxides along the shears. The vein also contains traces of caloite and galena.

About 100 feet west of the vin is a 3 foot syenite dike with approximately the same brend as the wain. A strongly altered basic dike, 10 feet wide, is exposed in the road out 300 feet west of the win. The dike cannot be traced in either direction, but the trend appears to be about the same as that of the syenite and the rin. Both the thowlnm-ixaring woin and the syenite dike have been offset by a serofes of east and northeast-trending faults.

Eight samples were collected from locations shown on figure 19. They contals iscom a trace to 0.6 percent equivalent $\mathrm{ThO}_{2}$ (table 9) and the spectographic analyses showed traces of rare earth oxides (\$2มmples RA-11-15 -96-100)。

\section{Spalding propertst}

The John Spalding property is about 0.4 miles, S. $50 \mathrm{~W}$. from the ower's home on Route 143, northwest of Ilse (fig. 2). Io $P_{0}$ Dellwig examined the claim in July 1951 (Preliminary Reconnaissance Report D-263). The workings consist of one 40- Loot shaft and 5 prospect pits.

A quartz-barito rein in a shear zone strikes $\mathrm{N}_{0} 25^{\circ} \mathrm{W}$, and dips $85^{\circ}$ SW. Across microcline granite and injection gneiss. The foliation of the countzy rook strikes N. $45^{\circ} \mathrm{E}$. and dips $75^{\circ}$ NW. It was followed for 150 feet along stixike, but is reported to extend for 0.5 miles. The width varied from 18 to 24 inches. The radioactivity is low; however, the radioactivity was highest where shattered barite has been cemented by hematite 


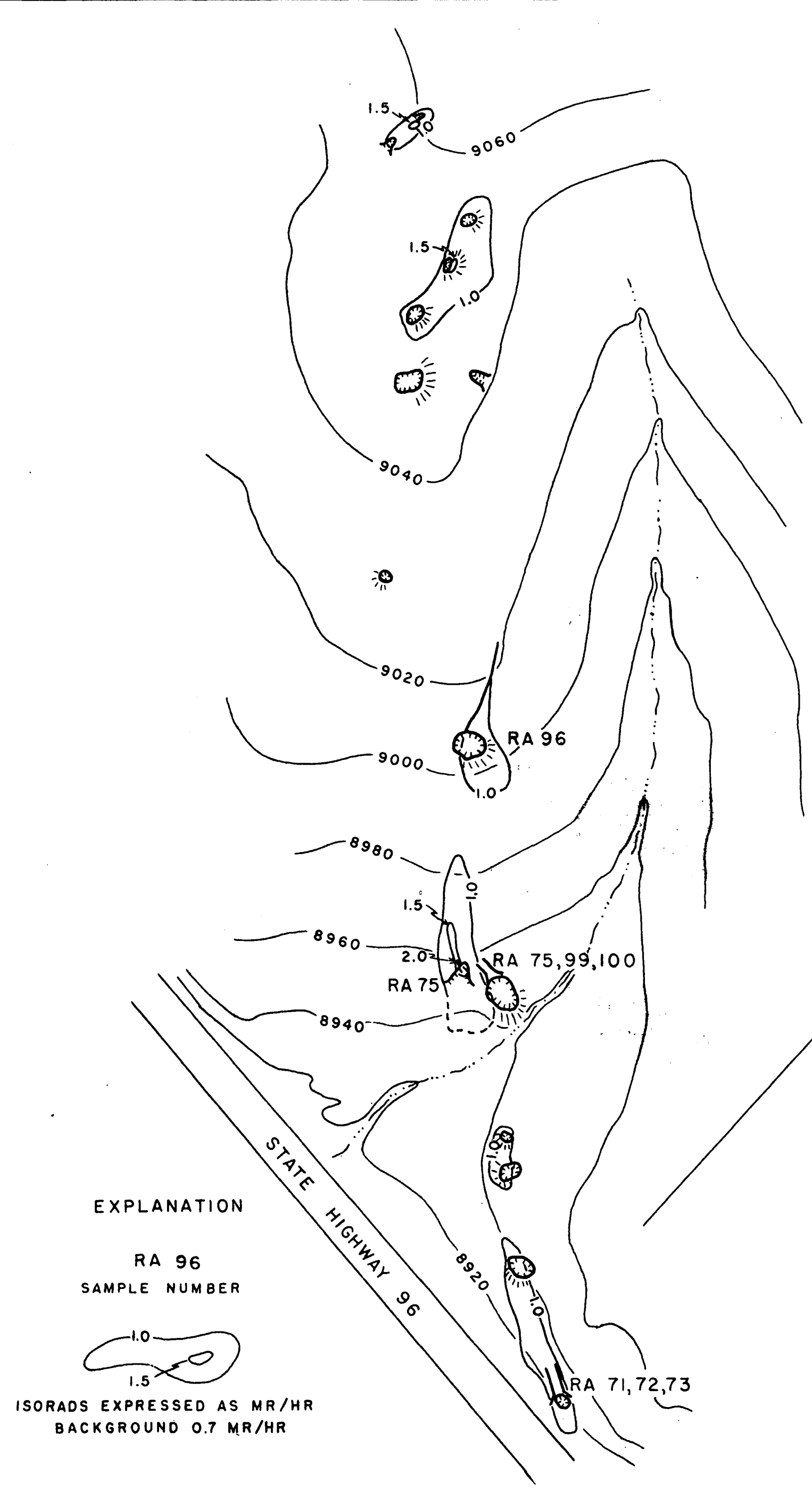

FIGURE I 9.

SORAD MAP OF PART OF SEWELL RANCH, CUSTER CO., COLORADO

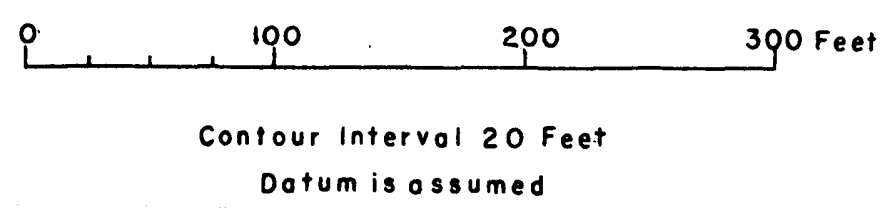


(3) and ar unkowow black mineral. The maximum reading was 14.0 on the 0.2

scale of a CeigeroMueller counter. Quartz and barite are the dominant vein minerals, but locally a fibrous blue amphibole (?) is abundant. Presumably the latter causes some of the quartz and barite to bo pale blue. Calena is a minor vein mineral.

Sample LD-36 (table 9) contains a trace of equivalent $\mathrm{ThO}_{2}$ and repreo sents the highest radioactive material on a dump 150 feet southeast of the shaft.

\section{Starbuek elaim}

The Starbuck elaim is six miles north of Querida (fig. 2) on the north side of a ridge locally called "Atomic Mountain". The claim was staked E. Soarling and L. Knobbe, and consists of eight prospect pits and a partially caved adit (fig. 20). It was examined briefly by Christman and Heyman in 1952.

The prospect pits occur along a vertical shear zone, 1,000 feet long, that trends $N_{0} 35^{\circ}$ W. The shear zone cuts granite gneiss, biotite schist, and amphibolite. The vein has a meximum observed width of 3 feet and is composed of quartz, barite, and large amounts of limonite and hematite.

Although the entire shear is weakly radioactive, the concentrations of thoriumminerals are near the adit and the southeastern prospect pit. A three-foot channel sample $(\mathrm{RA}-25)$ from this prospect contained 0.1 perc cent equivalent $\mathrm{ThO}_{2}$; other more selective samples ( $\mathrm{RA}-26$ and $\mathrm{KR} \rightarrow 8$ ) from the same pit contained 1.0 and 2.0 percent equivalent $\mathrm{ThO}_{2}$ (table 9). A selected sample (RA-28) from the dump at the caved adit contained 1.7 percent equivas lent $\mathrm{ThO}_{2}$; and a 0.5 foot channel sample from a prospect pit northwest of the adit contained 0.3 percent equivalent $\mathrm{ThO}_{2}$. 


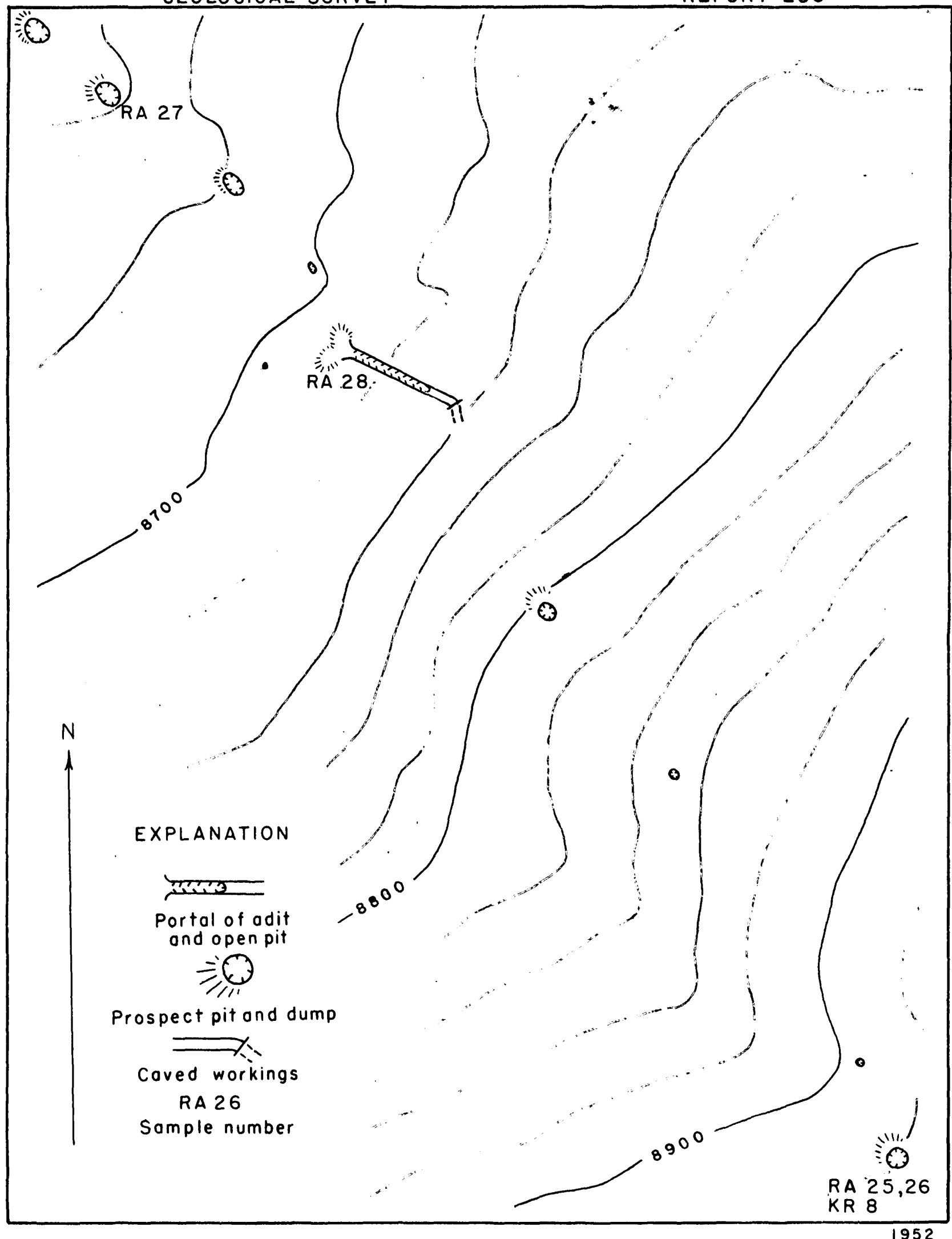

FIGURE 20. - PROSPECTS ON STARBUCK CLAIM, CUSTER CO., COLORADO 每, $100 \quad 200 \quad 300$ Feet 
Stinkhole claim

The Stinkhole claim, owned by George Stultz, is approximately 1.8 miles north of the Tuttle ranch (fig. 2). The locality was visited by Heyman in September 1951. The workings consisted of one shaft, an adjacent prospect pit, and a second prospect pit about one hundred feet to the southeast.

The country rock is dominantly granite with minor hornblende-plagioclase gneiss. A vein two feet thick transects the foliation of the country rock at a high angle and occurs in a shear zone that strikes N. $40^{\circ} \mathrm{W}$ and dips $55^{\circ}$ SW. A mafic dike characterized by alligned feldspar phenocrysts, trends $N$. $65^{\circ} \mathrm{W}$. through the south pit. Radioactivity is moderately high; much of the vein material on the dumps gave readings on the 2.0 scale; a high reading of 18 on the 2.0 scale was recorded. The dominant vein minerals are white and red fractured barite cemented by red radioactive material and massive, smoky quartz. Specular hematite and limonite mixed with thorite (?) occur disseminated through the vẹin and as coatings on barite and quartz. Siderite is found in small amounts, but its former abundance is recognized by rhomboherdral cavities in the quartz associated with abundant limonite. Lead has been reported. The fetid odor of the vein material is very strong, especially in the smoky quartz.

Two samples from the Stinkhole claim were analyzed. They contain 1.7 percent and 0.2 percent equivalent thorium (Samples AH-2, 3, table 9).

\section{Sunrise claims}

The Sunrise claims I, II, and III are in a rather inaccessible area, two miles northeast of the Tuttle ranch (fig.2). The owner, George Stultz, has worked the Sunrise I claim for barite and some lead was reported to have 
been sold. Heyman examined the properties in September 1951.

On the Sunrise I and II claims a vertical vein of baxite, three feet thick, has been mined out to a depth of 25 feet for 30 feet along the strike. Southeast of this cut there are numerous prospect pits and adits along the vein. There is one prospect pit on the Sunrise III eIaim.

The Sunrise I and II claims are on a northwesterly wrending vein to the southwest of the parallel vein on which Sunrise III is located. Both. veins occur in shear zones that cut pre-Cambrian granites and gneisses. Where mined, the Sunrise I and II vein was pure white barite with only minor impurities of quartz, carbonate, and galena. Several hundred feet to the southeast the vein branches into five veinlets each a few inches wide. A sheared lamprophyre dike is present wherever the vein is exposed. Although both veins may be traced for over one half mile, the radioactivity is low and very localized. At one point on Sunrise III, radioastive material giving 2.0-scale readings is present. Radioactivity at Sunrise I and II is negligible。

The orje sample analyzed ( $\mathrm{AH}-4$, table 9) was from the most radioactive portion of Sunrise III and, therefore, indicates maximum radioactivity。 The chemical uranium content is 0.027 percent - unusually high for this area; the equivalent $\mathrm{ThO}_{2}$ content of one sample was 1.2 percent.

\section{Swartz property}

Two propect pits on a patented (?) claim owned by D. P. Van Nouhuys in the northern part of the Swartz ranch were briefly examined by Heyman and Christman (Preliminary Reconnaissance Report D-471)。 The Swartz ranch is on Colorado route 96, two miles north of Querida. The pits occur on. 
either side of Tyndall Gulch about 1,000 feet apart and are probably along a shear zone which trends N. $28^{\circ} \mathrm{W}$.

The country rock at the southeast pit is metagabbro (?); at the northwest pit it is hornblende-plagioclase gneiss. The mineralized material is associated with sheared wall rock and a silicified dike rock. The only vein minerals recognized were limonite and hematite which mask the radioactive minerals, presumably thorite.

One sample of the most highly radioactive material from each pit was submitted for analyses to represent maximum $\mathrm{ThO}_{2}$. The sample ( $\mathrm{RA}_{-52}$ ) from the northwest pit contained 2.2 percent equivalent $\mathrm{ThO}_{2}$ and the sample (RA-5I) from the southeast pit contained 6.8 percent equivalent $\mathrm{ThO}_{2}$. The pits are badly slumped so that the amount of the vein material is unknown; it is probably small as the known radioactive material is restricted to a few specimens on dumps. 
94

REFERENCES CITED

Cross, Whitman, 1896, Geology of Silver Cliff and the Rosita Hills, Colo.: U.S.Geol。' Survey, 17th Annual report, pp. 269-403.

Emmons, S. F。, 1896, The mines of Custer County, Colo.: U。 S. Geol. Survey 17 th Annual report, pp. 411-472.

UNPUBLISHED REPORTS

Dellwig, L. F。, 1951, Preliminary summary report on the Wet Mountains Thorium area, Custer and Fremont Counties, Colorado: U. S. Geol. Survey Trace Elements Mem。Rept。287.

Dellwig, L。F。, and Get, G。 B., 1951, Radioactive deposits on the Haputa ranch, Custer County, Colorado: U.S. Geol. Survey Trace Elements Mem Rept. 285. 